RAFAEL GOMES AQUINO DE ARAÚJO

\title{
TRANSPORTADOR ABC E RESISTÊNCIA A BENZNIDAZOL EM Trypanosoma cruzi
}

Dissertação apresentada ao Programa de Pós-Graduação em Biologia da Relação Pátogeno-Hospedeiro do Instituto de Ciências Biomédicas da Universidade de São Paulo, para obtenção do título de Mestre em Ciências. 


\section{RAFAEL GOMES AQUINO DE ARAÚJO}

\section{Transportador $\mathrm{ABC}$ e resistência a benznidazol em \\ Trypanosoma cruzi}

Dissertação apresentada ao Programa de Pós-Graduação em Biologia da Relação Pátogeno-Hospedeiro do Instituto de Ciências Biomédicas da Universidade de São Paulo, para obtenção do título de Mestre em Ciências.

Área de concentração: Parasitologia

Orientadora: Profa. Dra. Bianca Silvana Zingales

Versão original 


\section{DADOS DE CATALOGAÇÃO NA PUBLICAÇÃO (CIP)}

Serviço de Biblioteca e Informação Biomédica do Instituto de Ciências Biomédicas da Universidade de São Paulo

() reprodução total

Araújo, Rafael Gomes Aquino de.

Transportador $\mathrm{ABC}$ e resistência a benznidazol em Trypanosoma cruzi / Rafael Gomes Aquino de Araújo. -- São Paulo, 2011.

Orientador: Bianca Silvana Zingales.

Dissertação (Mestrado) - Universidade de São Paulo. Instituto de Ciências Biomédicas. Departamento de Parasitologia. Área de concentração: Biologia da Relação Patógeno-Hospedeiro. Linha de pesquisa: Biologia molecular do Trypanosoma cruzi.

Versão do titulo para o inglês: $A B C$ transporter and benznidazole resistance in Trypanosoma cruzi.

Descritores: 1. Trypanosoma cruzi 2. Benznidazol 3. Transportador $A B C$ 4. Transfecção 5. Resistência a drogas 6. Cepas I. Zingales, Bianca Silvana II. Universidade de São Paulo. Instituto de Ciências Biomédicas. Programa de Pós-Graduação em Biologia da Relação Patógeno-Hospedeiro III. Título. 
Candidato(a): $\quad$ Rafael Gomes Aquino de Araújo.

Título da Dissertação: Transportador $A B C$ e resistência a benznidazol em Trypanosoma cruzi.

Orientador(a): Bianca Silvana Zingales.

A Comissão Julgadora dos trabalhos de Defesa da Dissertação de Mestrado, em sessão pública realizada a ....................,

( ) Aprovado(a) ( ) Reprovado(a)

Examinador(a): Nome completo: Instituição:

Examinador(a): Nome completo: Instituição:

Presidente: $\quad$ Nome completo: Instituição: 


\section{UNIVERSIDADE DE SÃo PAULO}

INSTITUTO DE CIÊNCIAS BIOMÉDICAS

Cidade Universitaria "Armando de Salles Olivaira"

Av. Prof. Lineu Prostes, 2415 - cep. 05508-000 São Paulo, SP - Brasil

Telefone :(55) (011) 3091.7733 - teletax : (55) (011) 30917438

-mail: cep@icb.usp.br

Of.CEPSH. 140.09

PMAZ/mcgn

São Paulo, 18 de junho de 2008

Prezado Senhor.

A comissã̃o em sessảo de 16.06 .09 analisou o pedido de isenção para o Projeto: "Transportador ABC e resistência a benznidazol em trypanosoma cruzi", deliberou em solicitar autorização do responsável para o uso das amostras e o cadastro da teca junto a esta comissāo. Modelo constante no site: icb.usp.br/ética em pesquisa com seres humanos.

Contando com a sua atenção e providências, despeço-me.

Atenciosamente,

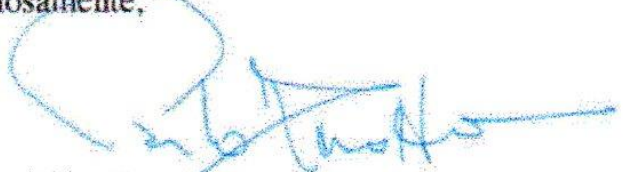

Prof. Dr. Paoto A. M.ZANotTo

Vice Coordenador da Comissão de Ética em

Pesquisas com Seres Humanos - ICB /USP

Ilmo. Sr.

RAFAEL GOMES AQUTNO DE ARAÚJO

Departamento de Parasitologia

Instituto de Ciências Biomédicas da USP

Comissăo de Ética em Pesquisa com Seres Humanos do Instituto de Ciências Blomédicas / USP Aprovada pela Comissăo Nacional de Etica em Pesquisa-CONEP, em 10 de fevereiro de 1998. 
Aos meus pais principalmente e atenciosamente, com afeto, admiração e gratidão por sua compreensão, carinho, presença, apoio incansável e amor incondicional ao longo do período de elaboração deste trabalho e desde o dia em que cheguei a este mundo. 


\section{AGRADECIMENTOS}

Mais um ciclo de minha vida se completa com a finalização deste trabalho. Recomeçase um novo caminho a ser traçado com expectativa e entusiasmo, agora sob uma perspectiva mais madura, consciente e otimista em relação ao futuro, que acena como um novo raio de sol brilhante no horizonte de possibilidades.

Agradeço a Deus, pela oportunidade de viver com saúde, paz e alegria.

Meu anjo da guarda, por sempre estar ao meu lado em todos os momentos, nos melhores e naqueles mais difíceis também.

Profa. Bianca Zingales, pelas oportunidades de estudo e aprendizagem concedidas, pela confiança em meu trabalho, pela revisão cuidadosa de relatórios, apresentações e desta tese, por me ensinar a buscar o conhecimento profundo sobre a Biologia Molecular, auxiliando-me a raciocinar, planejar metodologias, analisar dados e escrever como um cientista, por estimular minha proatividade e autonomia intelectual e, particularmente, por inspirar-me a ser um profissional com excelência acadêmica.

Meus grandes amigos: Jany Pereira, Maína Machado, Carol Machado, Ana Luiza Cecconi, Marc Halsberghe, Elcio Fernandes e Guilherme Carmelo, pelo companheirismo durante todos estes anos, especialmente no período em que estive na USP, pela ajuda nos momentos difíceis, pelas discussões acadêmicas (ou não), pelas conversas maravilhosas, pelos conselhos amigos, pelas horas de amor fraternal divididas, pelo ombro nas horas tristes, pelas dificuldades superadas, pela proximidade afetuosa e pela amizade verdadeira.

Susan Ienne, pelo trabalho em equipe, colaboração, exemplo de organização e incetivo profissional, pelos ensinamentos e pelas conversas íntimas, pelo caráter e integridade moral, pela amizade que começou no laboratório e tenho certeza de que durará para sempre.

Marcelo Nunes, por ser um profissional solícito e prestativo, constantemente disposto a colaborar, além de ser um amigo e companheiros de todos, sempre com um sorriso no rosto. Jaques Franco, pelo esforço, dedicação e bom humor costumeiros. Simone Fernandes e Vanessa Vidotto, pelo alto astral, convivência e amizade. Solange Lessa, pelas conversas e 
conselhos sobre os mais diversos assuntos, especialmente os profissionais e espiritualistas. Eva Souza, pelo exemplo de dedicação e perseverança, mesmo diante das situações mais difíceis na vida. Obrigado a todos pela força!

Prof. Carlos Renato Machado, pela colaboração neste trabalho, pela acolhida em Belo Horizonte, por toda a atenção, cuidado e orientação nas semanas em que passei pela UFMG. Pedro Aguiar, pelo acompanhamento dedicado e fraterno em meus experimentos no Laboratório de Genética Bioquímica. João Pedro da Rocha, Matheus Rajão, Carolina Furtado, Selma Santos e a todos os queridos alunos do LGB, que me trataram com tanto carinho e receptividade, meus sinceros agradecimentos.

Denis Jacob, por me apresentar o mundo fantástico da Filogenia e me indicar excelentes ferramentas, materiais e dicas para meus trabalhos e análises, e por continuar a amizade até o final do mestrado. Todos os meus colegas da Biologia, Bioquímica, Educação e Biomédicas, com quem tive momentos de alegria e com quem muito aprendi durante as disciplinas e excelentes cursos dos quais tive a honra de participar.

Prof. Paulo Cotrim, pelo material fornecido e pelas instruções sobre os testes in vitro. Profa. Silvia Uliana e prof. Alejandro Katzin, pelas ótimas discussões sobre o projeto e proveitosos conselhos para o melhor aproveitamento em meus últimos meses de mestrado.

Pessoal dos laboratórios dos professores Hugo Armelin e Fábio Forte, sempre atenciosos e dispostos a ajudar nos momentos em que precisei, além dos laboratórios dos professores Alexander Henning, Ohara Augusto, Carla Columbano e alguns outros, pela ajuda em diversas ocasiões. Luci Navarro, por seu profissionalismo, competência, simpatia e solicitude durante todo o curso do mestrado, sempre no auxílio rápido e eficiente com os sequenciamentos.

Profa. Mari Cleide Sogayar, Marluce Montovani, Ana Cláudia Carreira e todos que me auxiliaram nos experimentos de eletroporação e no uso do microscópio de fluorescência. Meu amigo querido Rômulo Carvalho, pela inspiração como biomédico, pela cativante amizade, pelas conversas agradáveis, pelo carinho ímpar e por todos os incríveis passeios em que me levou na cidade de São Paulo. 
Professores Jeffrey Shaw e Myriam Krasilchik, dois de meus honrados e maravilhosos professores de pós-graduação, com os quais muito aprendi e os quais tanto admiro. Pelo exemplo de carisma, didática, ética e por me mostrarem como um verdadeiro professor deve ser: dedicado e amigo, fazendo seu melhor trabalho como educador e formador de alunos profundos e preparados para a vida.

Profa. Margareth Capurro, André Costa da Silva e Bianca Burini, pela paciência, dedicação e acompanhamento em meu primeiro contato com um laboratório científico da USP, e por terem me indicado o bem sucedido mestrado com a profa. Bianca Zingales.

Meus cativantes amigos e colegas do grupo de teatro na USP, especialmente Bia Svat, Lu Pasquarelli, Thomas Fessel, Gustavo Ribeiro, Elisa Estroniolli, Stephanie Brum, Gabriel Mormilho, Deborah Ferraz, Dionísio Gutierres e meus "filhos" Pedro Pereira e Yasmine Pereira, com os quais aprendi a ser mais humano, a me doar de corpo e alma pela arte, a olhar verdadeiramente nos olhos de pessoas queridas, a revelar o Charles Chaplin que existe dentro de mim, a descobrir que teatro é vida condensada, a me entregar aos palcos da vida.

Grupo Seven da USP, por meio do qual conheci pessoas tão queridas e divertidas, como Cesar Augusto Mayor, Jeferson Hugo Rezende e Marcelo Valpeteris, e todos aqueles que de alguma maneira estiveram ao meu lado e torceram por mim.

Renato Nunes, meu querido amigo, que viajou ao Plano Astral no final do último mês de julho, e a quem continuarei espiritualmente ligado pelos laços sinceros de amizade por toda a eternidade. Obrigado por sempre me dizer palavras de carinho, de incentivo, de apoio, de ternura, de amor fraterno. Amo-te verdadeiramente, amigo!

Meus amigos e familiares de Goiânia, que mesmo distantes fisicamente, conseguiram me dar forças durante o caminho.

CNPq, CAPES e FAPESP pelo apoio financeiro no desenvolvimento deste trabalho. 
"O ignorante afirma, o sábio duvida, o sensato reflete."

Aristóteles 


\section{RESUMO}

Araújo RGA. Transportador ABC e resistência a benznidazol em Trypanosoma cruzi. [Dissertação (Mestrado em Parasitologia)]. São Paulo: Instituto de Ciências Biomédicas da Universidade de São Paulo; 2011.

Apenas Benznidazol (BZ) e Nifurtimox (NFX) estão disponíveis para o tratamento da doença de Chagas, causada pelo protozoário Trypanosoma cruzi. Ensaios clínicos indicam haver diferenças regionais na eficácia do tratamento, atribuídas, em parte, a diferenças na suscetibilidade de cepas de T. cruzi as duas drogas. Vários transportadores ABC (ATP binding cassette) desempenham um papel importante na resistência a drogas. Evidências obtidas por nosso grupo indicam que um transportador $\mathrm{ABC}$ de $T$. cruzi, o TcABCG1, é superexpresso em cepas resistentes a BZ. Desta forma, o objetivo geral de nosso projeto foi obter evidências adicionais para o envolvimento de TcABCG1 no fenótipo de resistência a BZ. Os objetivos específicos do estudo foram: (i) verificar a ação de inibidores de transportadores $\mathrm{ABC}$ na resistência a $\mathrm{BZ}$; (ii) verificar se a superexpressão do gene $T c A B C G 1$ altera a suscetibilidade a BZ de uma cepa sensível; (iii) determinar o número de cópias do gene $T c A B C G 1$ em algumas cepas de $T$. cruzi; (iv) caracterizar os genes de transportadores $\mathrm{ABC}$ presentes no genoma da cepa CL Brener. Após determinação da $\mathrm{CI}_{50}$ para $\mathrm{BZ}$ de seis cepas e sua classificação em suscetíveis $(\mathrm{S})$ e resistentes $(\mathrm{R})$, o efeito de três inibidores de transportadores $\mathrm{ABC}$ de eucariotos foi investigado. Concluímos que apenas verapamil aumentou a suscetibilidade a BZ das cepas. O gene TcABCGl das cepas Berenice 62 (S), VL10 (R); Silvio (R) e YuYu (R) foi clonado e sequenciado. Transfectamos em CL Brener (S) os genes TcABCG1 das cepas VL10, Silvio e YuYu, consideradas resistentes a BZ. Os genes foram clonados no vetor pROCKNeo. Nas culturas transfectadas com os genes de Silvio e YuYu, verificamos aumento da resistência a BZ de 26 e 32\%, respectivamente. Nas culturas transfectadas com os genes de VL10 e CL Brener, o incremento da resistência foi da ordem de $10 \%$. Nas culturas transfectadas houve também aumento da resistência a NFX. A abundância relativa dos transcritos do gene $T c A B C G 1$ foi determinada por RT-PCR em tempo real. Nas culturas transfectadas com o gene ABC de CL Brener, Silvio e YuYu houve aumento da abundância relativa de transcritos de $T c A B C G 1$ de 2,70, 2,85 e 2,67 vezes, respectivamente. Nas culturas transfectadas com o gene de VL10 e com o vetor vazio a abundância relativa dos transcritos foi de 1,12 e 0,80 vezes, respectivamente. Não encontramos diferenças no número de cópias do gene TcABCG1 em cepas naturalmente sensíveis e resistentes a BZ. As evidências obtidas apoiam a hipótese de que o transportador 
TcABCG1 seja um dos elementos envolvidos no fenótipo de resistência a BZ (e NFX) em $T$. cruzi. Utilizando ferramentas de bioinformática, identificamos 58 transportadores $\mathrm{ABC}$ hipotéticos no genoma de CL Brener, 36 dos quais possuem um alelo anotado. Estes genes distribuem-se em 16 dos 41 cromossomos. Genes ABC ortólogos aos de T. cruzi foram identificados em tripanossomas africanos e Leishmania spp. Dados referentes a análises filogenéticas e classificação dos transportadores $\mathrm{ABC}$ de $T$. cruzi nas oito subfamílias (A-H) das proteínas $\mathrm{ABC}$ de eucariotos são apresentados.

Palavras-chave: Trypanosoma cruzi. Benznidazol. Transportador ABC. Transfecção. Resistência a drogas. Cepas. 


\begin{abstract}
Araújo RGA. ABC transporter and benznidazole resistance in Trypanosoma cruzi. [Masters thesis (Parasitology)]. São Paulo: Instituto de Ciências Biomédicas da Universidade de São Paulo; 2011.
\end{abstract}

Benznidazole (BZ) and Nifurtimox (NFX) are the only available drugs for the treatment of Chagas disease, caused by the protozoan Trypanosoma cruzi. Clinical trials indicate regional differences in the treatment outcome, attributed in part to differences in the drug susceptibility of $T$. cruzi strains. Several ABC (ATP binding cassette) transporters play an important role in drug resistance. Evidence obtained by our group indicates that a T. cruzi ABC transporter, TcABCG1, is overexpressed in BZ-resistant strains. Thus, the overall goal of our project was to obtain additional evidence for the involvement of TcABCG1 in BZ resistance. The specific goals of the study were: (i) to verify the activity of $\mathrm{ABC}$ transporter inhibitors in $\mathrm{BZ}$ resistance; (ii) to assess whether the overexpression of the TcABCG1 gene alters the susceptibility to $\mathrm{BZ}$ in a BZ-susceptible strain; (iii) to determine the number of TcABCGI gene copies in some T. cruzi strains; (iv) to characterize the ABC transporter genes in CL Brener genome. After determining the $\mathrm{IC}_{50}$ to $\mathrm{BZ}$ in six strains and their classification into susceptible (S) and resistant (R), the effect of three inhibitors of eukaryotic ABC transporters was investigated. Only verapamil increased BZ susceptibility in all the strains. The TcABCG1 gene of Berenice $62(\mathrm{~S})$, VL10 (R), Silvio (R) and YuYu (R) strains was cloned and sequenced. We transfected in CL Brener (S) TcABCG1 genes of VL10, YuYu and Silvio strains, considered BZ-resistant. The genes were cloned into the pROCKNeo vector. In cultures transfected with Silvio and YuYu genes, an increased BZ resistance of 26 and 32\%, respectively, was observed. In cultures transfected with the VL10 and CL Brener genes, the increase in drug resistance was approximately $10 \%$. In the transfected cultures resistance to NFX was also increased. The relative $T c A B C G 1$ transcript abundance was determined by real time RT-PCR. In cultures transfected with the CL Brener, Silvio and YuYu gene the increase of transcript abundance was 2.70-; 2.85; and 2.67-fold, respectively. In cultures transfected with the VL10 gene and with the empty vector the transcript abundance increased 1.12- and 0.80 -fold, respectively. No differences in the TcABCG1 gene copy number in naturally BZsusceptible and resistant strains were observed. The evidence obtained in this study support the hypothesis that TcABCG1 transporter is one of the elements involved in the BZ (and NFX) resistance phenotype. By using bioinformatics tools, we identified 58 hypothetical $\mathrm{ABC}$ transporters in CL Brener genome, 36 of which have an annotated allele. The genes are 
distributed in 16 of the 41 chromosomes. ABC orthologous genes to those of T. cruzi were identified in African trypanosomes and Leishmania spp. Data regarding the phylogenetic analysis and classification of T. cruzi ABC transporters in eight subfamilies (A-H) of eukaryote $\mathrm{ABC}$ proteins are presented.

Keywords: Trypanosoma cruzi. Benznidazole. ABC transporter. Transfection. Drug resistance. Strains. 


\section{LISTA DE ILUSTRAÇÕES}

Figura 1 - Representação esquemática do ciclo de vida do T. cruzi

Figura 2 - Estrutura química das drogas atualmente disponíveis para o tratamento etiológico da doença de Chagas: Nifurtimox e Benznidazol.

Figura 3 - Representação esquemática da estrutura de proteínas $\mathrm{ABC}$ em parasitas protozoários.

Figura 4 - Abundância relativa de transcritos do gene ABC de T. cruzi em cepas sensíveis e resistentes a BZ.

Figura 5 - Representação de um transportador $\mathrm{ABC}$ formado por dois meiotransportadores, que necessitam homodimerizar para formar uma proteína funcional

Figura 6 - Sequência nucleotídica completa do gene $T c A B C G 1$.

Figura 7 - Alinhamento das sequências de aminoácidos do gene TcABCG1 de CL Brener haplótipos Esmeraldo e Não Esmeraldo, Berenice 62, Silvio X10, VL10 e YuYu.

Figura 8 - Mapa do vetor pROCKGFPNeo.

Figura 9 - Southern Blot: DNA genômico de CL Brener WT e transfectado com pROCKNeo vazio e pROCKNeo com o TcABCGl de CL Brener e VL10, e da cepa Silvio WT, digerido com BamHI e SalI

Figura 10 - Digestão de DNA genômico com SacII.

Figura 11 - PCR em Tempo Real para estimar o número de cópias do gene TcABCG1 a partir de massa conhecida de DNA de cinco cepas.

Figura 12 - Representação esquemática dos 41 cromossomos de CL Brener e localização de famílias gênicas.

Figura 13 - Localização celular putativa das proteínas ABC de T. cruzi.

Figura 14 - Árvore de transportadores ABC de T. cruzi gerada pelo método neighborjoining.

Figura 15 - Subfamílias de transportadores ABC de T. cruzi. .74

Figura 16 - Investimento cumulativo para obter-se uma nova droga.

Figura A.1 - Estrutura secundária da proteína TcABCG1 do haplótipo Não-Esmo de 
Figura A.2 - Southern Blotting de DNA genômico de seis cepas de T. cruzi digerido com HindIII e hibridizado com a sonda TcABCG1 de $616 \mathrm{pb}$ marcada $\operatorname{com} \mathrm{P}^{32}$

Figura A.3 - Sequência proteica completa de TcABCG1 de três grupos de cepas...............100 


\section{LISTA DE TABELAS}

Tabela 1 - Associação entre as Discrete Typing Units (DTUs) de T. cruzi e reservatórios silvestres, vetores, distribuição geográfica e manifestações da doença de Chagas.

Tabela 2 - Similaridade por BLASTP do transportador TcABCG1 e membros da subfamília ABCG de humanos e de duas espécies de Leishmania.

Tabela 3 - Características dos iniciadores utilizados no sequenciamento do gene TcABCG1.

Tabela 4 - Características de cepas de T. cruzi utilizadas no estudo.

Tabela 5 - Efeito de inibidores de transportadores $\mathrm{ABC}$ no crescimento de formas epimastigotas da cepa CL Brener e VL10.

Tabela 6 - Efeito de verapamil na suscetibilidade a BZ $\left(\mathrm{CI}_{50}\right)$ em cepas de $T$. cruzi.

Tabela 7 - Efeito de ciclosporina A na suscetibilidade a BZ $\left(\mathrm{CI}_{50}\right)$ em cepas de $T$. cruzi.

Tabela 8 - Suscetibilidade a BZ de CL Brener selvagem (WT) e transfectado com o gene $T c A B C G 1$ de diferentes cepas.

Tabela 9 - Suscetibilidade a NFX de CL Brener selvagem (WT) e transfectado com o gene $T c A B C G 1$ de diferentes cepas

Tabela 10 - Sinal de hibridização da sonda do gene ABC a partir de dados do Southern Blot

Tabela 11 - Razão da abundância relativa de transcritos de $T c A B C G 1$ .66

Tabela 12 - Estimativa da abundância do gene TcABCG1 por PCR em tempo real. .68

Tabela 13 - Características dos transportadores ABC de T. cruzi identificados no genoma de CL Brener.

Tabela A.1 - Genes de transportadores ABC de T. cruzi alelos e ortólogos a espécies de Leishmania e tripanossomas africanos. 


\section{LISTA DE ABREVIATURAS E SIGLAS}

$\mu \mathrm{M}$

$\mu 1$

$\mathrm{ABC}$

$\mathrm{ABCP}$

ATP

BCRP

BZ

cDNA

$\mathrm{CI}_{50}$

DEPC

DMSO

DNA

dNTP

DTU

EDTA

EL

FTC

GAPDH

$\mathrm{H}_{2} \mathrm{O}$

$\mathrm{H}_{2} \mathrm{O}_{2}$

$\mathrm{HCl}$

HUGO

IPTG

$\mathrm{kb}$

$\mathrm{KCl}$

kpxls

LB

LIB

LIT

$\mathrm{Mb}$

MDR

Micromolar

Microlitros

ATP Binding Cassette

Placenta Specific ABC

Adenosina Trifosfato

Breast Cancer Resistance Protein

Benznidazol

Fita complementar de DNA

Concentração de droga que inibe o crescimento celular em 50\%

Dietilpirocarobonato

Dimetilsulfóxido

Ácido Desoxirribonucleico

Desoxirribonucleotídeo Fosfatado

Discrete Typing Unit

Ethylenediaminetetraacetic Acid

Haplótipo Esmeraldo

Fumitremorgin C

Gliceraldeído-3-Fosfato Desidrogenase

Água

Peróxido de Hidrogênio

Ácido Clorídrico

Gene Nomenclature Committee

Isopropyl $\beta$-D-1-thiogalactopyranoside

Kilobases

Cloreto de Potássio

Kilopixels

Luria Bertani

Liver Infusion Broth

Liver Infusion Tryptose

Megabases

Multidrug Resistance 
$\mathrm{ml}$

MLEE

MRP

MXR

$\mathrm{Na}_{2} \mathrm{HPO}_{4}$

$\mathrm{NaCl}$

$\mathrm{NaOAc}$

NBD

NEL

NFX

$\mathrm{O}_{2}$

ORF

OYE

PBS

PCR

PFGE

PFGRC

PGP

PRP

RAPD

RNA

$\mathrm{RNO}_{2}$

RT-PCR

SDS

SFB

SOB

SOC

SOD

SSC

TBE

TMD

WT
Mililitros

Multi-Locus Enzyme Electrophoresis

Multidrug Resistance Protein

Mitoxantrona Resistance Protein

Fosfato de Sódio Dibásico

Cloreto de Sódio

Acetato de Sódio

Nucleotide Binding Domain

Haplótipo Não-Esmeraldo

Nifurtimox

Gás Oxigênio

Open Reading Frame

Old Yellow Enzyme

Phosphate-Buffered Saline

Reação em Cadeia da Polimerase

Eletroforese de Campo Pulsado

Pathogen Functional Genomics Resource Center

Glicoproteína-P

Pentamidine Resistance Protein

Randomly Amplified Polymorphic DNA

Ácido Ribonucleico

Radical Nitroânion

Reação em Cadeia da Polimerase com Transcrição Reversa

Lauril Sulfato de Sódio

Soro Fetal Bovino

Super Optimal Broth

Super Optimal Broth with Catabolic repressor

Superóxido Dismutase

Saline-Sodium Citrate

Tris-Borato-EDTA

Transmembrane Domain

Wild Type 


\section{LISTA DE SÍMBOLOS}

$\begin{array}{ll}\mathrm{C}_{\mathrm{T}} & \text { Cycle Threshold } \\ { }^{\circ} \mathrm{C} & \text { graus Celsius }\end{array}$

\section{AMINOÁCIDOS}

Ácido aspártico D

Ácido glutâmico E

Alanina A

Arginina $\quad \mathrm{R}$

Asparagina $\mathrm{N}$

Cisteína $\quad \mathrm{C}$

Fenilalanina $\quad \mathrm{F}$

Glicina G

Glutamina Q

Histidina $\quad \mathrm{H}$

Isoleucina I

Leucina L

Lisina $\mathrm{K}$

Metionina $\quad \mathrm{M}$

Prolina P

Serina $\quad S$

Tirosina Y

Treonina $\mathrm{T}$

Triptófano W

Valina $\quad \mathrm{V}$

BASES NITROGENADAS DOS NUCLEOTÍDEOS

$\begin{array}{ll}\text { Adenina } & \text { A } \\ \text { Citosina } & \text { C } \\ \text { Guanina } & \text { G } \\ \text { Timina } & \text { T }\end{array}$




\section{SUMÁRIO}

1 INTRODUÇÃO ...................................................................................................................23

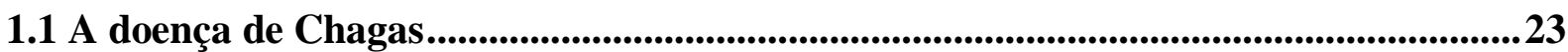

1.2 Ciclo evolutivo, variabilidade genética e nomenclatura do $T$. cruzi ...............................23

1.3 Eficácia do tratamento e suscetibilidade de cepas de $T$. cruzi a quimioterápicos.......26

1.4 Mecanismos de resistência a drogas.........................................................................................28

1.5 Transportadores $\mathrm{ABC}$...........................................................................................................29

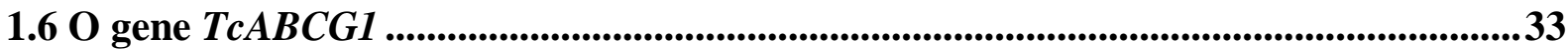

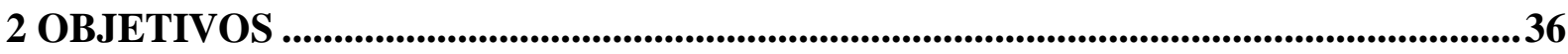

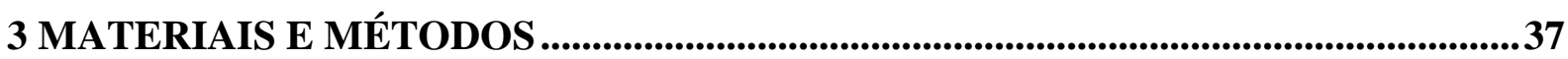

3.1 Meios e Soluções...........................................................................................................................37

3.2 Cepas e culturas de $T$. cruzi ……...........................................................................................37

3.3 Determinação da suscetibilidade a drogas ...........................................................................38

3.3.1 Determinação da suscetibilidade a BZ...................................................................................38

3.3.2 Determinação da suscetibilidade a NFX ............................................................................38

3.4 Efeito de inibidores de transportadores $\mathrm{ABC}$ na suscetibilidade a BZ ..........................38

3.5 Manutenção de formas epimastigotas de $T$. cruzi - congelamento e descongelamento .38

3.6 Estocagem de formas epimastigotas para extração de DNA/RNA .................................39

3.6.1 Extração de DNA total de formas epimastigotas................................................................39

3.6.2 Extração de RNA total de formas epimastigotas .................................................................39

3.7 Bactérias competentes ....................................................................................................................40

3.8 Clonagem do gene TCABCG1 .................................................................................................40

3.8.1 Amplificaçã o do gene ..............................................................................................................40

3.8.2 Purificação do produto de PCR .............................................................................................41

3.8.3 Adição de adenina ao produto de PCR ..............................................................................41

3.8.4 Ligação ao vetor de clonagem ..................................................................................................41

3.8.5 Transformação em bactérias competentes DH5a .............................................................42

3.8.6 PCR de colônia ........................................................................................................................42

3.8.7 Purificação de DNA plasmidial...............................................................................................43

3.9 Sequenciamento do gene TcABCG1 ...................................................................................43

3.10 Transfecção do gene TcABCG1 em T. cruzi ………...........................................................44 
3.10.1 Liberação do gene TcABCG1 do vetor de clonagem ...................................................44

3.10.2 Clonagem do gene TCABCG1 no vetor pROCKNeo ......................................................45

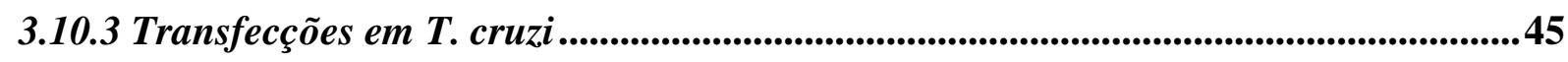

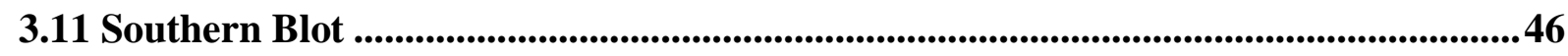

3.12 Obtenção de sondas radioativas e condições de hibridização.........................................46

3.12.1 Marcação por random primer extension ....................................................................46

3.12.2 Hibridização de sondas radioativas com ácidos nucléicos imobilizados .....................46

3.12.3 Lavagem das membranas ................................................................................................................47

3.12.4 Desibridização das membranas .............................................................................................47

3.13 PCR em tempo real para determinação do número de cópias do gene $T c A B C G 1$...47

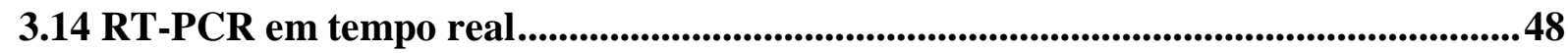

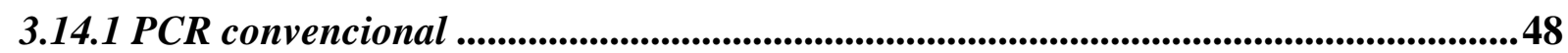

3.14.2 Síntese da primeira fita de cDNA ..................................................................49

3.14.3 Síntese da segunda fita de cDNA e PCR em tempo real ..........................................49

3.14.4 Teste da eficiência de amplificação ....................................................................49

3.14.5 Análises dos dados ...................................................................................................50

3.15 Identificação e caracterização de genes de $T$. cruzi para transportadores ABC .......50

3.16 Análises filogenéticas e classificação dos transportadores ABC de T. cruzi..............51

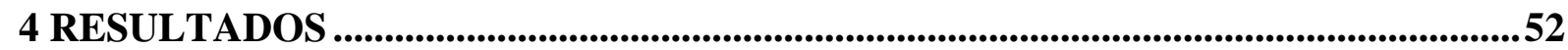

4.1 Determinação da suscetibilidade a BZ em cepas de $T$. cruzi ..........................................52

4.2 Efeito de inibidores de transportadores $\mathrm{ABC}$ na suscetibilidade a BZ ......................53

4.3 Caracterização do gene do transportador $T c A B C G 1$ de $T$. cruzi ....................................55

4.3.1 Amplificação da sequência completa do gene TcABCG1 .........................................55

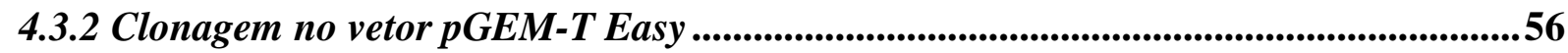

4.3.3 Análises das sequências do gene TcABCG1 de cepas de T. cruzi ...................................56

4.4 Transfecção de genes TcABCG1 de cepas de T. cruzi em CL Brener ...........................58

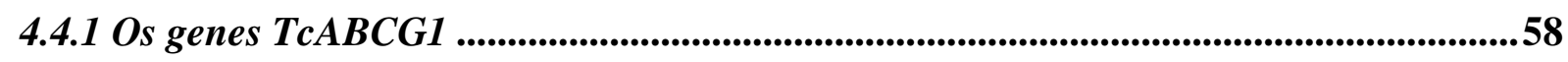

4.4.2 Transfecç̃̃es em T. cruzi ......................................................................................................59

4.4.3 Suscetibilidade a $\mathrm{BZ}$ e $\mathrm{NFX}$..................................................................................................60

4.4.4 Localização do gene TcABCG1 no genoma dos parasitas transfectados.....................61

4.4.5 Abundância de transcritos de TcABCG1 nas culturas transfectadas ..........................65

4.4.6 Quantificação da razão de abundância do gene TcABCG1 em cepas selvagens.........66

4.5 Caracterização de proteínas ABC de $T$. cruzi .....................................................67 
4.5.1 Identificação de proteínas ABC no genoma de CL Brener. .67

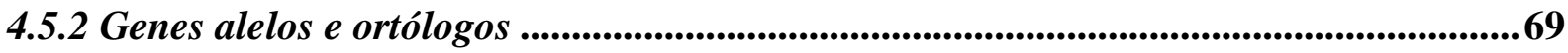

4.5.3 Localização cromossômica dos transportadores ABC de T. cruzi ................................70

4.5.4 Análise da estrutura das proteínas ABC hipotéticas ..................................................70

4.5.5 Análisse filogenéticsa e classificação dos transportadores $A B C$ de T. cruzi ................71

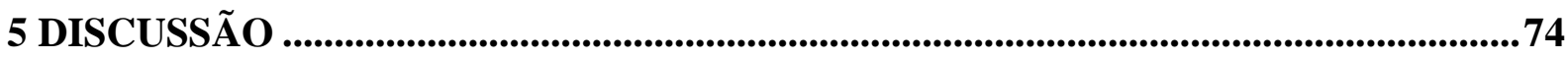

5.1 Suscetibilidade a $\mathrm{BZ}$ e o efeito de inibidores de transportadores $\mathrm{ABC}$.........................74

5.2 Cópias do gene $T c A B C G 1$ em cepas de $T$. cruzi ........................................................76

5.3 Estrutura do gene $T c A B C G 1$ de cepas de $T$. cruzi ...............................................................76

5.5 Abundância de transcritos de $T c A B C G 1$ nos transfectantes .......................................78

5.6 Filogenia de transportadores ABC de $T$. cruzi .......................................................79

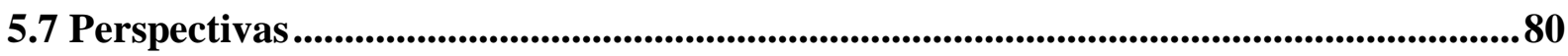

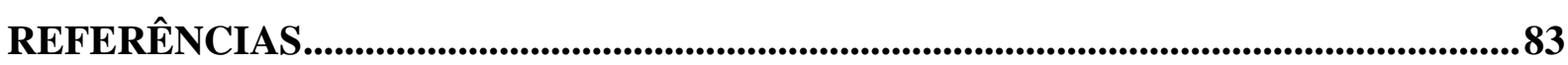

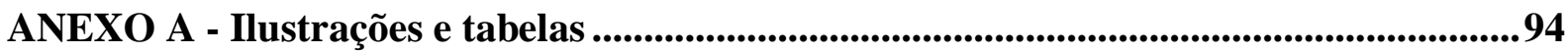




\section{INTRODUÇÃO}

\subsection{A doença de Chagas}

O parasita protozoário Trypanosoma cruzi, agente causador da doença de Chagas, infecta 7,7 milhões de pessoas na América Latina, onde mais de 100 milhões de pessoas se encontram em situação de risco. A doença de Chagas causa cerca de 12.500 mortes anuais (Rassi Jr. et al., 2010). A transmissão do parasita ocorre mais frequentemente quando fezes do inseto vetor triatomínio, contaminadas com o protozoário, entram em contato com a pele ou mucosa do hospedeiro humano. A maior morbidade da doença ocorre na fase crônica, que pode levar vários anos para se desenvolver. Não existe vacina contra o T. cruzi e o tratamento é restrito a duas drogas, benznidazol (BZ) e nifurtimox (NFX), com eficácia parcial, efeitos colaterais potencialmente prejudiciais e tratamentos longos (60 dias) (Urbina, 2010).

As manifestações clínicas clássicas da doença de Chagas derivam da infecção das células musculares cardíacas, levando a uma cardiomiopatia progressiva. A cardiomiopatia chagásica é a maior causa de infarto cardíaco na América Latina, sendo a morte súbita responsável por 55-65\% desses casos. No Brasil, o desenvolvimento de megassíndromes também é comum (Rassi Jr. et al., 2010).

A transmissão vetorial é a principal forma de infecção por $T$. cruzi, que também pode ocorrer por transfusão sanguínea, transmissão congênita, ingestão de bebidas ou alimentos contaminados com o parasita, transplante de órgãos e acidentes laboratoriais (Dias, 2000; Moncayo, 2003). Além disso, a migração de indivíduos infectados provenientes de áreas endêmicas tem elevado os índices da doença de Chagas na Europa, América do Norte, Japão e Austrália (Schmunis, 2007). O controle da transmissão vetorial e transfusional permanece como uma das mais importantes formas de profilaxia da doença.

\subsection{Ciclo evolutivo, variabilidade genética e nomenclatura do T. cruzi}

O T. cruzi é um parasita digenético que tem insetos triatomíneos da família Reduviidae, subfamília Triatominae, comumente chamados de barbeiros, como hospedeiros intermediários, e mamíferos, como hospedeiros definitivos. O parasita apresenta um ciclo de vida complexo (Figura 1) e três formas evolutivas distintas, que são nomeadas de acordo com a posição do cinetoplasto em relação ao núcleo e à região de emergência do flagelo. Estas formas evolutivas são: a epimastigota (forma flagelada, replicativa no intestino do inseto e 
não infectante); a tripomastigota (forma flagelada, infectante,não replicativa e presente no vetor e nos hospedeiros mamíferos); e a amastigota (forma com pequeno flagelo intracelular, replicativa, presente nos mamíferos e possivelmente infectante). A tripomastigota é a forma que representa o elo de ligação entre o vetor e os hospedeiros mamíferos (Brener, 1973; De Souza, 2003).

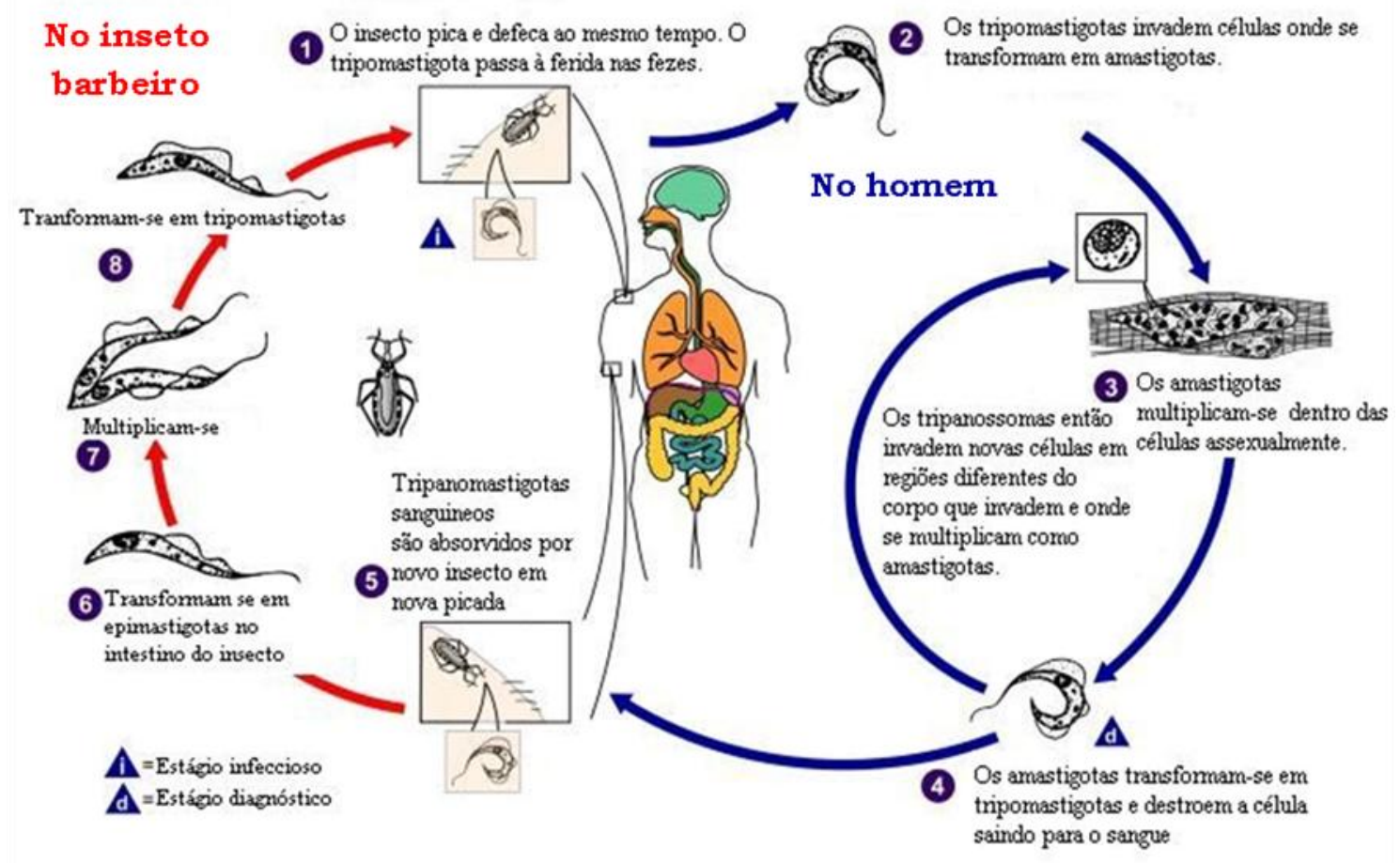

Figura 1 - Representação esquemática do ciclo de vida do T. cruzi. Extraído de Laboratory Identification of Parasites of Public Health Concern: Fonte: CDC's Division of Parasitic Diseases and Malaria (DPDM, 2010).

Quando o inseto vetor se alimenta com sangue do mamífero, defeca, e as formas tripomastigotas metacíclicas, eliminadas nas fezes, atravessam a pele ou mucosa do hospedeiro e penetram nas células próximas ao local da picada. Na célula, transformam-se em amastigotas, que se multiplicam no citoplasma e, após várias gerações, diferenciam-se em tripomastigotas, que são liberadas na corrente sangüínea e podem infectar células de vários tecidos, como muscular, cardíaco ou nervoso. Mais recentemente, foi descrita uma forma epimastigota intracelular, intermediária entre a forma amastigota e tripomastigota (Silber et al., 2009)

Os insetos triatomíneos são infectados com formas tripomastigotas sanguíneas ao se alimentarem do sangue do mamífero contaminado. No intestino médio do inseto, as tripomastigotas se diferenciam em formas epimastigotas e, no final do tubo digestivo, parte 
destas formas se diferencia em tripomastigotas metacíclicas, que são eliminados nas fezes quando o inseto se alimenta novamente, começando assim um novo ciclo de infecção (De Souza et al., 2003).

O T. cruzi apresenta considerável polimorfismo genético. Este fato foi demonstrado com base no perfil eletroforético de isoenzimas (Multi-Locus Enzyme Electrophoresis, MLEE) (Miles et al., 1978; Tibayrenc e Breniere, 1988), análise de fragmentos de restrição do DNA do cinetoplasto (Morel et al., 1980), impressões digitais do DNA (DNA fingerprinting) (Macedo et al., 1992), amplificação randômica do DNA polimórfico (Randomly Amplified Polymorphic DNA, RAPD) e polimorfismo de genes de RNA ribossômico (rRNA) e do miniéxon (Souto et al., 1996). Apesar da grande diversidade genética, a primeira evidência da existência de dois grupos principais de T. cruzi foi sugerida a partir da interpretação de dados de tipagem do gene de rRNA 24S $\alpha$ e mini-éxon (Souto et al., 1996), dados de MLEE e RAPD (Tibayrenc, 1995) e atividade do promotor de rRNA (Floeter-Winter et al., 1997), dentre outros.

Tabela 1 - Associação entre as Discrete Typing Units (DTUs) de T. cruzi e reservatórios silvestres, vetores, distribuição geográfica e manifestações da doença de Chagas.

\begin{tabular}{|c|c|c|c|c|}
\hline DTU & $\begin{array}{c}\text { Reservatórios } \\
\text { silvestres }\end{array}$ & Vetores silvestres & $\begin{array}{c}\text { Distribuição } \\
\text { Geográfica }\end{array}$ & Doença de Chagas \\
\hline TcI & $\begin{array}{l}\text { Marsupiais, } \\
\text { roedores e primatas }\end{array}$ & $\begin{array}{c}\text { Rhodnius } \\
\text { Panstrongylus } \\
\text { Triatoma } \\
\text { Eratyrus }\end{array}$ & $\begin{array}{c}\text { Américas do Sul, } \\
\text { Norte e Central }\end{array}$ & Cardiomiopatia \\
\hline TcII & $\begin{array}{l}\text { Primatas de } \\
\text { florestas do } \\
\text { Atlântico e } \\
\text { marsupiais }\end{array}$ & $\begin{array}{l}\text { Não conhecidos } \\
\text { completamente }\end{array}$ & Cone Sul & $\begin{array}{l}\text { Cardiomiopatia e } \\
\text { megassíndromes }\end{array}$ \\
\hline TcIII & Tatus & P. geniculatus & América do Sul & $\begin{array}{l}\text { Raro em humanos. } \\
\text { Forma clínica pouco } \\
\text { conhecida }\end{array}$ \\
\hline TcIV & Primatas & $\begin{array}{c}\text { Rhodnius, } \\
\text { Panstrongylus, } \\
\text { Triatoma }\end{array}$ & $\begin{array}{l}\text { Américas do Sul } \\
\text { e do Norte }\end{array}$ & $\begin{array}{c}\text { Causa secundária de } \\
\text { doença de Chagas na } \\
\text { Venezuela. Casos } \\
\text { esporádicos em outras } \\
\text { regiões da América do Sul }\end{array}$ \\
\hline $\mathrm{TcV}$ & Pouco conhecidos & Pouco conhecidos & Cone Sul & $\begin{array}{l}\text { Cardiomiopatia e } \\
\text { megassíndromes }\end{array}$ \\
\hline $\mathrm{TcVI}$ & Pouco conhecidos & Pouco conhecidos & Cone Sul & $\begin{array}{l}\text { Cardiomiopatia e } \\
\text { megassíndromes }\end{array}$ \\
\hline
\end{tabular}

Fonte: Compilada a partir de Miles et al., 2009. 
Múltiplas estratégias de genotipagem apoiam a subdivisão de $T$. cruzi em seis grupos filogenéticos principais, recentemente nomeados como DTUs (TcI-TcVI) por consenso internacional (Zingales et al., 2009). A associação de cada DTU com vetores e reservatórios mamíferos, e com as manifestações da doença de Chagas, bem como sua distribuição geográfica, foi definida recentemente (Miles et al., 2009) (Tabela 1). Deste quadro, resulta que as seis DTUs são capazes de promover a doença de Chagas humana, embora sejam raros os casos promovidos por TcIII (Miles et al., 2009) (Tabela 1).

Experimentos in vitro e em modelos experimentais indicam uma variação fenotípica significante entre as cepas de T. cruzi (De Souza et al., 2011; Machado et al., 2006; Ramirez et al., 2010; Zingales et al., 1999) e em características do parasita relacionadas com a virulência, parasitemia, tropismo tissular, patologia e resistência a drogas (De Diego et al., 1998; Mejia e Triana, 2005; Toledo et al., 2002).

\subsection{Eficácia do tratamento e suscetibilidade de cepas de $T$. cruzi a quimioterápicos}

O objetivo do tratamento específico da doença de Chagas é a eliminação total do parasita do indivíduo infectado, evitando assim o desenvolvimento da doença. Apenas duas drogas, benznidazol (N-benzil-2-nitroimidazol acetamida) e nifurtimox (5-nitrofurano 3metil-4-(5'-nitrofurfurilideneamina) tetrahidro-4H-1,4-tiazina-1,1-dioxido) (Figura 2) estão disponíveis para o tratamento da doença, sendo bastante eficazes na fase aguda e crônica recente.
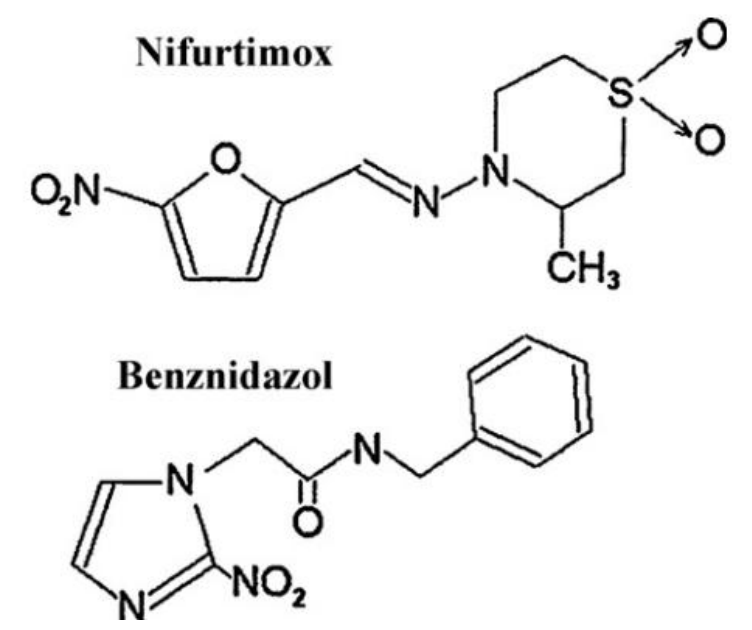

Figura 2 - Estrutura química das drogas atualmente disponíveis para o tratamento etiológico da doença de Chagas: Nifurtimox e Benznidazol. 
De fato, numerosas triagens clínicas mostraram até $80 \%$ de cura parasitológica na fase aguda e 60-70\% de cura na fase crônica recente em crianças de até 14 anos de idade (De Andrade et al., 1996; Sosa-Estani et al., 1998, 2009; Yun et al., 2009). Em adultos na fase crônica, apenas 5-20\% de pacientes foram considerados curados (Cançado, 2001; Dias 2006). Por outro lado, o tratamento com BZ na fase crônica leva a um melhor prognóstico da evolução clínica das cariomiopatias chagásicas e é recomendado por especialistas (SosaEstani et al., 2009; Viotti et al., 2006).

Novas drogas para o tratamento da doença de Chagas, que permitam um tratamento mais curto e apresentem menos efeitos colaterais, são necessárias. Azóis antifúngicos, como posaconazol, ravuconazol e TAK187, têm-se mostrado eficazes em modelos experimentais (Corrales et al., 2005; Pinazo et al., 2010; Urbina et al., 2003). Um estudo clínico de fase 2 foi iniciado em meados de 2010 com o composto triazólico de nova geração E-1224 (Azoles E1224 \& Biomarker, 2011). Além disso, estudos estão em andamento para produzir novos derivados de BZ (Nogueira Silva et al., 2008). A combinação de compostos já existentes, que apresentam diferentes mecanismos de ação, vem sendo proposta como uma abordagem alternativa para o desenvolvimento de novos tratamentos (Benaim et al., 2006).

BZ e NFX são pró-drogas que agem diretamente no parasita após serem ativadas por nitrorredutases próprias (Wilkinson et al., 2008). Durante o processo de bioativação, metabólitos quimicamente reativos são formados. Para NFX, forma-se o radical nitroânion $\left(\mathrm{RNO}_{2}{ }^{-}\right)$, ao passo que para $\mathrm{BZ}$ forma-se o radical hidronitróxido (RNHO). As reações do $\mathrm{RNO}_{2}{ }^{-}$com oxigênio podem levar ao ciclo de oxidorredução para a formação no ânion superóxido de $\mathrm{O}_{2}^{-}$(Castro et al., 2006). No caso de BZ, o processo nitrorredutivo é seguido pela formação do amino derivado correspondente e, durante a biotransformação, um metabólito reativo é formado (RNHO). Acredita-se que a toxicidade de BZ surja a partir da interação de alguns destes metabólitos reativos com o DNA, proteínas e lipídeos ou outros componentes celulares importantes (De Toranzo e Castro, 1994; Gorla et al., 1986; Masana et al., 1985).

As razões para a diferença marcante na eficácia antiparasitária de compostos nitroheterocíclicos nas fases agudas e crônicas da doença não são claros (Cançado, 2002), mas podem estar relacionadas com as propriedades farmacocinéticas das drogas, como por exemplo, meia-vida curta e baixa penetração nos tecidos (Raaflaub, 1980; Workman et al., 1984), o que limita sua ação na fase crônica quando os parasitas estão confinados nos tecidos onde apresentam replicação lenta (Urbina, 2003; Urbina e Docampo, 2003). 
Foram descritas diferenças regionais no declínio de anticorpos anti-T. cruzi em resposta ao tratamento com BZ. A queda no nível de anticorpos ocorre mais prontamente em pacientes de países do norte da América do Sul e América Central, quando comparada com pacientes de países do Cone Sul e Estados Unidos (Yun et al., 2009). Esta observação fala a favor de diferentes suscetibilidades das cepas infectantes às drogas utilizadas, bem como de possíveis diferenças na imunogenética dos indivíduos infectados.

Nos últimos 25 anos, foram claramente documentadas diferenças de suscetibilidade a BZ e NFX em muitas cepas de T. cruzi isoladas de diferentes hospedeiros e áreas geográficas (Andrade et al., 1992; Filardi e Brener, 1987; Murta et al., 1998; Toledo et al., 2002).

Em trabalho seminal, Filardi e Brener (1987) determinaram a suscetibilidade a BZ e NFX em 47 cepas de $T$. cruzi isoladas de pacientes, vetores domésticos e silvestres e de reservatórios silvestres. Estes isolados foram inoculados em camundongos que foram tratados alternativamente com os dois nitroderivados, monitorando-se a porcentagem de cura 20 dias pós-tratamento. Os autores verificaram que a eficiência terapêutica variava entre $0 \%$ a $100 \%$, classificando as cepas em resistentes ( 0 a 33\% de cura); intermediárias (33 a 66\%) e sensíveis (66 a 100\%). Curiosamente, neste modelo foi verificado um comportamento semelhante na eficácia de NFX e BZ. É também relevante comentar que cepas resistentes às duas drogas são resistentes a outros compostos (revisto em Coura e Castro, 2002; Urbina e Docampo, 2003).

Em seu projeto de doutoramento, realizado em nosso laboratório, Margoth Moreno Vigo padronizou um ensaio in vitro para quantificar a sensibilidade a $\mathrm{BZ}$ em formas epimastigotas de cerca de 20 isolados do T. cruzi (Moreno Vigo, 2008). O valor de $\mathrm{CI}_{50}$, concentração de droga que inibe o crescimento celular em 50\%, dos isolados variou de 7,6 $\mu \mathrm{M}$ a $127 \mu \mathrm{M}$ BZ (Moreno et al., 2010). Cinco dos isolados analisados constaram do trabalho de Filardi e Brener (1987) descrito acima, observando-se uma correlação entre o valor de CI $_{50}$ para BZ de epimastigotas e a eficácia do tratamento em camundongos infectados.

\subsection{Mecanismos de resistência a drogas}

Os mecanismos envolvidos no fenômeno de resistência a BZ e NFX foram investigados por diferentes abordagens em isolados cuja resistência foi induzida por pressão seletiva com as drogas. Neste contexto, foi verificado que a deleção de cópias do gene que codifica a "old yellow enzyme" (TcOYE) promove resistência a BZ (Murta et al., 2006). A proteína TcOYE é uma flavina oxidorredutase $\mathrm{NAD}(\mathrm{P}) \mathrm{H}$ dependente, que pode estar envolvida no metabolismo de BZ, gerando radicais ânions tóxicos para o parasita. Cabe 
ressaltar, no entanto, que a expressão do gene TcOYE encontra-se reprimida unicamente em parasitas com resistência induzida, mas não em parasitas que apresentaram resistência natural a BZ (Murta et al., 2006). Mais recentemente, foi descrito que a perda de uma cópia do gene que codifica uma nitrorredutase mitocondrial, responsável pela ativação das pró-drogas NFX e BZ, é suficiente para causar resistência a uma variedade de drogas nitroheterocíclicas (Wilkinson et al., 2008). Superóxido dismutases (SOD) também foram implicadas no fenótipo de resistência a drogas em T. cruzi. Esta classe de enzimas atua removendo o excesso $\mathrm{O}_{2}{ }^{-}$, gerado no estresse oxidativo, via dismutação a $\mathrm{O}_{2}$ e $\mathrm{H}_{2} \mathrm{O}_{2}$. Temperton et al. (1998) transfectaram formas epimastigotas com um vetor contendo o gene Fe-SOD e observaram que a superexpressão desta enzima promovia um aumento na suscetibilidade a BZ. Por outro lado, em trabalho posterior, Nogueira et al. (2006) verificaram que parasitas com resistência a BZ induzida in vitro apresentavam superexpressão de FeSOD-A. Estes autores levantaram a possibilidade de que nestes parasitas haveria também a superexpressão de outras enzimas antioxidantes envolvidas no metabolismo de $\mathrm{H}_{2} \mathrm{O}_{2}$ e, desta forma, ocorreria a detoxificação do hidroperóxido, promovendo o fenótipo de resistência.

O conjunto de dados descritos acima sugere que o fenótipo de resistência induzida por pressão seletiva com BZ seja resultante da ação de diferentes mecanismos, que podem atuar de forma independente ou concertada. Além disto, sugerem diferenças entre os determinantes que atuam no processo de resistência induzida e resistência natural a BZ.

A aquisição de resistência a multidrogas é um sério problema no tratamento de muitas doenças virais, bacterianas, parasitárias e no câncer. A resistência celular a uma única classe de drogas citotóxicas pode surgir de diversas maneiras, incluindo a inativação da droga, alteração do elemento alvo, diminuição da permeabilidade da membrana, mudanças no metabolismo da droga e bombeamento da droga para fora da célula (revisto em Dean e Anillo, 2005).

\subsection{Transportadores ABC}

Um dos principais mecanismos de resistência a multidrogas é o transporte ativo de drogas para fora da célula, mediado por transportadores que bombeiam um largo espectro de compostos citotóxicos, incluindo antibióticos, antimaláricos, herbicidas e quimioterápicos usados no tratamento de câncer (revisto em Higgins, 2007).

Estes transportadores são proteínas transmembranares de uma superfamília específica que apresenta sítios de ligação de ATP, sendo, por este motivo, denominados transportadores 
ABC (ATP binding cassette). A unidade funcional mínima de todos os transportadores $\mathrm{ABC}$ consiste em quatro domínios. Dois domínios citoplasmáticos, NBDs (nucleotide binding domains), que ligam e hidrolisam o ATP, e dois domínios transmembrana, TMDs (transmembrane domains), compostos por $\alpha$-hélices múltiplas (geralmente seis), que formam a estrutura pela qual os compostos atravessam a membrana. Os domínios estão unidos em um único polipeptídeo nas proteínas $\mathrm{ABC}$ completas. Os NBDs contêm em sua sequiência os motivos Walker A e Walker B (Walker et al., 1982) que são comuns a todas as proteínas que ligam ATP. Além disso, os domínios NBD possuem uma pequena sequência conservada chamada assinatura $\mathrm{ABC}$, que é típica dos membros da superfamília $\mathrm{ABC}$ (revisto em Higgins, 2007).

Dados estruturais, em conjunto com a caracterização genética e bioquímica destes transportadores, permitiram propor um modelo de transporte do tipo "ATP-interruptor" (Higgins e Linton, 2004). A força motriz para o transporte da droga é a mudança conformacional do dímero NBD. A ligação de ATP promove a rotação dos domínios NBDs e a formação de um dímero fechado que engloba duas moléculas de ATP. A hidrólise do ATP e liberação de ADP e Pi determinam a abertura do dímero. Esta cinética pode diferir entre transportadores, dependendo da extensão da cooperatividade entre os dois NBDs e os sinais provenientes dos TMDs. A ligação de ATP pelos NBDs e a formação do dímero fechado induzem mudanças conformacionais substanciais nos TMDs (Rosenberg et al., 2001), que medeiam a translocação do substrato - uma redução na afinidade de ligação ao composto - e a reorientação do sítio de ligação, que passa a ser exposto à face extracelular da membrana, momento em que o composto pode ser liberado (revisto em Higgins, 2007).

A superfamília de transportadores $\mathrm{ABC}$ está dividida em oito subfamílias (A-H), que se diferenciam quanto à homologia, número e arranjo dos NBDs e TMDs, localização celular e função. Membros das subfamílias B, C e G estão intimamente relacionados com o transporte de drogas, bombeando o composto para fora da célula, contra um gradiente de concentração, num processo dependente de energia (revisto em Higgins, 2007). Este é um dos mecanismos de resistência a drogas mais bem conhecidos, conservado desde bactérias até o homem (Lage, 2003). Membros da superfamília ABC, que incluem as glicoproteínas P (PGP ou ABCB) e outras proteínas associadas à resistência a múltiplas drogas (MDR, MRP ou ABCC), conferem o fenótipo de resistência a células tumorais (Germann, 1996). A representação esquemática da estrutura das subfamílias de transportadores $\mathrm{ABC}$ em parasitas protozoários (Sauvage et al., 2009) é mostrada na Figura 3. 


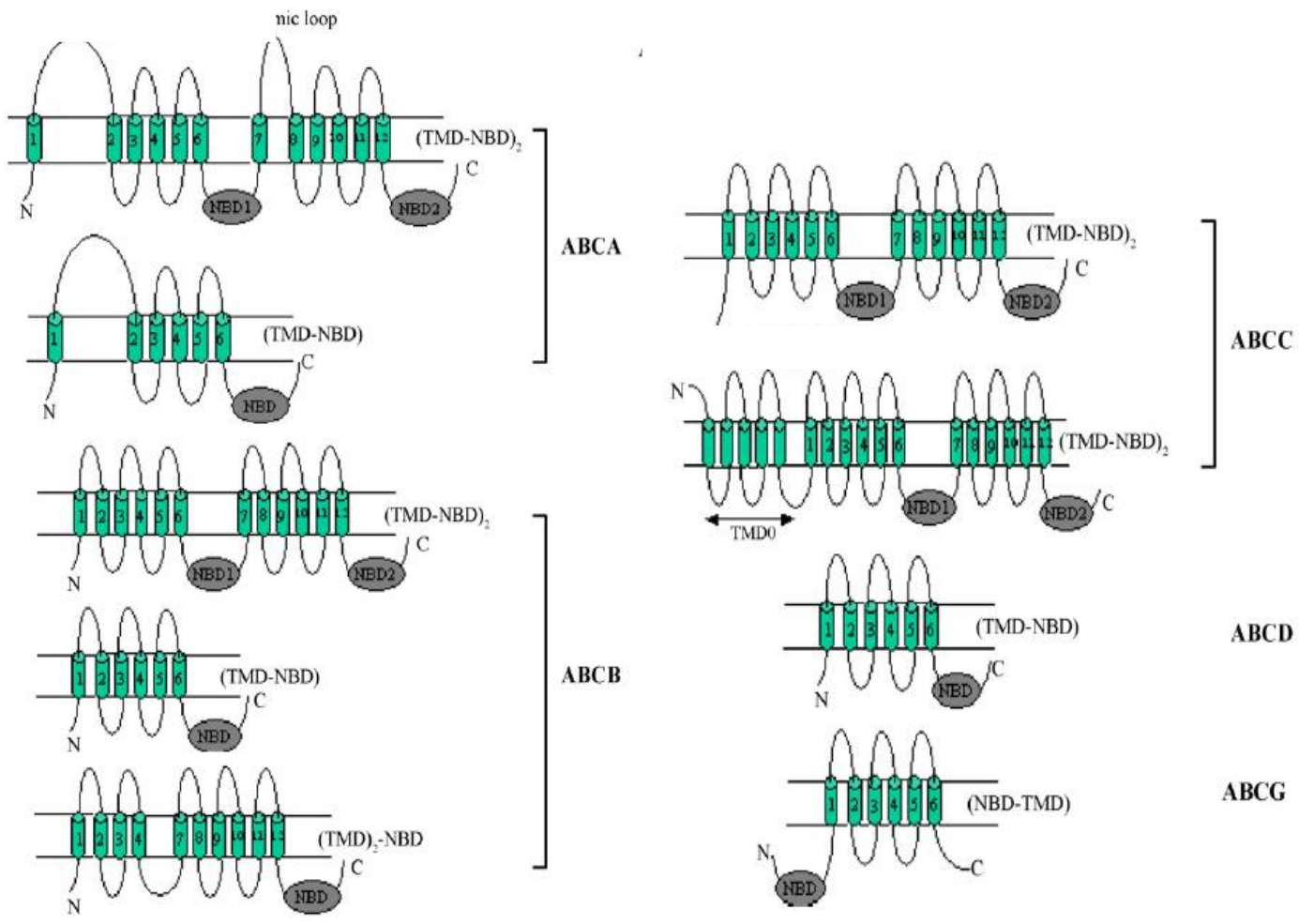

Figura 3 - Representação esquemática da estrutura de proteínas $\mathrm{ABC}$ em parasitas protozoários. A maioria dos transportadores das subfamílias ABCA, ABCB e ACCC contém dois TMDs e dois NBDs fundidos em um único polipeptídeo, representada pela topologia (TMD$\mathrm{NBD})_{2}$. Transportadores $\mathrm{ABC}$ conhecidos como meio-transportadores possuem um único TMD unido a um único NBD, representados pelos membros das subfamílias $\mathrm{ABCD}$ e ABCG. Transportadores das subfamílias E e F são citoplasmáticos e não estão representados nesta figura.

Fonte: Sauvage et al., 2009.

Genes que codificam proteínas $\mathrm{ABC}$ foram descritos em vários parasitas protozoários e seu papel na quimiorresistência foi estabelecido para alguns deles. Em populações de $L$. tarentolae e L. major, selecionadas pela resistência à droga metotrexato (MTX), foi observada a amplificação de um gene $\mathrm{ABC}$, denominado pgpA (atualmente classificado como $\mathrm{ABCB}$ ), localizado no DNA extracromossômico (Ouellette et al., 1990). A amplificação deste gene é um fenômeno comum em Leishmania, frequentemente relacionado com fenótipos de resistência a drogas. Experimentos de transfecção demonstraram o envolvimento de pgpA na resistência a arsenito e antimônio (Ouellette et al., 1998; Papadopoulou et al., 1992). O primeiro gene mdrl-like (atualmente classificado como ABCC) de Leishmania foi descrito no início dos anos 90 em uma linhagem de L. donovani (ldmdr1) resistente a vimblastina (Henderson et al., 1992). Posteriormente, genes homólogos foram descritos em linhagens de L. enrietti (Chow et al., 1993) e de L. amazonensis resistentes a vimblastina (Gueiros-Filho et al., 1995). Um transportador $\mathrm{ABC}$ de L. major, denominado PRP1 (pentamidine resistance 
protein 1), foi correlacionado com resistência a pentamidina (Coelho et al., 2003, 2007, 2008).

Em isolados de Plasmodium falciparum resistentes a cloroquina foi verificado que o efluxo desta droga encontra-se aumentado (Krogstad et al., 1987). A adição de verapamil, agente clássico de reversão de MDR em células animais, foi capaz de restaurar parcialmente a suscetibilidade a cloroquina (Martin et al., 1987). Estas observações levaram ao isolamento do gene do transportador $\mathrm{ABC}$ pfmdrl, que apresenta uma estrutura e sequência similar ao gene de glicoproteínas-P de mamíferos (Foote et al., 1989; Wilson et al., 1989). A ação antimalárica da cloroquina parece ocorrer no vacúolo digestivo dos estágios intraeritrocíticos do parasita, onde a droga interfere com a polimerização e detoxificação do grupo heme da hemoglobina. Mutações no gene de uma proteína transmembrana deste vacúolo, denominada PfCRT, foram associadas ao fenômeno de resistência à droga, por promoverem alteração em seu transporte e ligação ao heme (Fidock et al., 2000).

Dois transportadores ABC, TbMRPA e TbMRPE, estão envolvidos na resistência de Trypanosoma brucei a drogas tripanocidas (Shahi et al., 2002). O transportador TbAT1 é exigido para o bombardeamento para o meio extracelular de drogas arsenicais e de diamidinas (Barrett e Fairlamb, 1999). Isolados de T. brucei gambiense de pacientes do Sudão, Uganda e Angola resistentes a drogas apresentaram uma mutação no gene TbAT1 (Matovu et al., 2001).

Alguns transportadores $\mathrm{ABC}$ de $T$. cruzi foram caracterizados, os quais, aparentemente, não estão envolvidos em quimiorresistência. Inicialmente foram descritos os genes da Tcpgp1 e Tcpgp2 (Dallagiovanna et al., 1994, 1996). A seqüência de aminoácidos codificada por Tcpgpl apresenta similaridade com segmentos dos transportadores LtpgpA de L. tarentolae e HuMRP de humanos e o produto codificado por Tcpgp2 apresenta similaridade com a glicoproteína P de L. tarentolae, com o fator de calmodulina (YCF1) de levedura e com proteínas MDR associadas à resistência a drogas em humanos (Dallagiovanna et al., 1996). Estudos subsequentes mostraram que o fenótipo de resistência a BZ de T. cruzi não está associado à superexpressão ou à amplificação dos dois genes (Murta et al., 2006). Este resultado é concordante com as características e a classificação das proteínas por eles codificadas. Realizamos uma busca dos domínios conservados (Banco Prosite) nas proteínas Tcpgp1 e Tcpgp2 e pudemos constatar que Tcpgp1 não apresenta o motivo Walker B, mas sim o motivo Walker $\mathrm{A}$ e a assinatura $\mathrm{ABC}$. Esta proteína não possui o domínio transmembrana e, desta forma, sua localização seria citoplasmática. Este transportador poderia ser membro das subfamílias $\mathrm{ABCE}$ ou $\mathrm{ABCF}$, para as quais nenhuma função de transporte foi atribuída. Por outro lado, o transportador Tcpgp2 é um transportador ABC 
típico, com dois domínios citoplasmáticos de ligação de ATP e dois domínios transmembrana. Através de busca por homologia com transportadores de espécies próximas evolutivamente, deduzimos que este transportador pertenceria à subfamília ABCA. Membros desse grupo também não estão relacionados com o transporte de drogas.

Outro transportador $\mathrm{ABC}$ da subfamília A foi identificado em T. cruzi (Torres et al., 2004). $T c A B C 1$ (ou $T c A B C A 1$ ) é um gene de cópia única diferencialmente expresso durante o ciclo celular do parasita e ausente em tripomastigotas. TcABC1 está localizado na membrana plasmática, bolsa flagelar e vesículas intracelulares. Estudos funcionais de TcABC1 em parasitas transfectados sugerem que a proteína esteja implicada no tráfego intracelular e envolvida em vias de endocitose e exocitose (Torres et al., 2004).

$\mathrm{O}$ envolvimento de transportadores $\mathrm{ABC}$ no fenótipo de resistência a drogas pode ser confirmado pelo uso de inibidores específicos destes transportadores, tais como: verapamil, fumitremorgin C e ciclosporina A (Doyle e Ross, 2003; Ejendal e Hrycyna, 2004; Robey et al., 2008). Verapamil é um bloqueador de canais de Cálcio que também reverte a MDR em células de mamífero. Em Leishmania, um transportador ABC (ABCC7), denominado PRP1, foi associado ao fenótipo de resistência a pentamidina. Esta resistência foi revertida utilizando-se concentrações não tóxicas de verapamil (Coelho et al., 2003, 2007). A ciclosporina A inibe o transporte da droga mediado por Pgp e MRP, por interferir no reconhecimento do substrato e a hidrólise de ATP (Wagner-Souza et al., 2003). Fumitremorgin C (FTC) é um inibidor específico e seletivo da proteína do câncer de mama (BCRP) que confere resistência a doxorubicina, mitoxantrano e topotecano. A BCRP é um transportador $\mathrm{ABC}$, pertencente à subfamília $\mathrm{G}(\mathrm{ABCG} 2)$. FTC não atua em transportadores do tipo Pgp e MRP (Imai et al., 2002; Susanto et al., 2008).

\subsection{O gene TcABCG1}

Em seu projeto de doutoramento, Margoth Moreno Vigo analisou a expressão diferencial de genes em isolados de T. cruzi naturalmente suscetíveis ou resistentes a BZ, utilizando lâminas de microarranjos de DNA preparadas pelo Pathogen Functional Genomics Resource Center (PFGRC) do TIGR, que contêm oligonucleotídeos representantes de 12.288 ORFs de CL Brener (Moreno Vigo, 2008).

Dentre a série de genes diferencialmente expressos entre a cepa sensível e a cepa resistente a $\mathrm{BZ}$, foram identificados três genes que codificam transportadores $\mathrm{ABC}$ putativos, superexpressos na cepa resistente. Os estudos foram concentrados em um destes genes ABC 
(Tc00.1047053508231.190), que apresenta 1998 pb e codifica 665 aminoácidos. Ensaios de RT-PCR em tempo real (Figura 4) confirmaram os dados dos microarranjos e mostraram maior abundância de transcritos deste gene em 5 isolados resistentes a BZ em relação a 3 isolados sensíveis (com 95\% de confiança ao se aplicar o teste de Student) (Moreno Vigo, 2008).

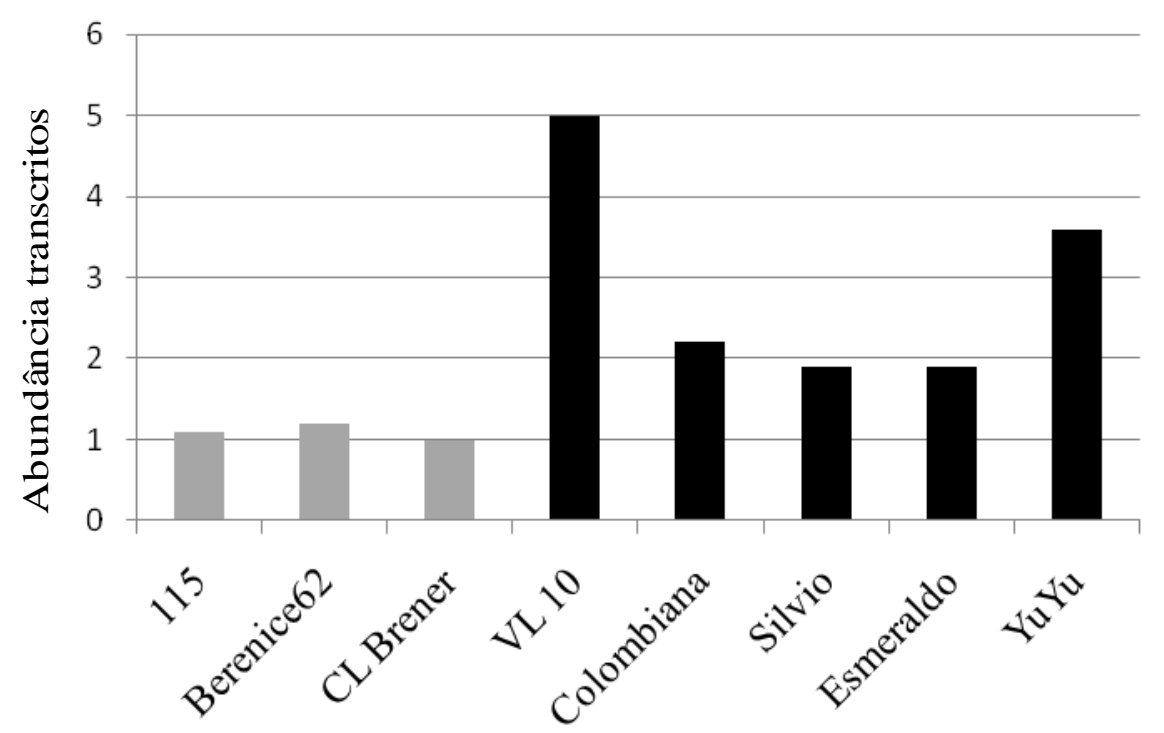

Figura 4 - Abundância relativa de transcritos do gene $\mathrm{ABC}$ de $T$. cruzi em cepas sensíveis (barras cinzas) e resistentes (barras pretas) a BZ. Dados obtidos por RT-PCR em tempo real Fonte: Moreno Vigo, 2008.

O transportador $\mathrm{ABC}$ mais expresso em cepas resistentes apresenta um único NBD e um único TMD composto de seis $\alpha$-hélices, sendo um meio-transportador. A análise da filogenia e da estrutura de sua sequência proteica sugere que o transportador pertença à subfamília G (Figura 3). Sendo o primeiro membro desta subfamília identificado em T. cruzi, decidimos denominá-lo TcABCG1. Meio-transportadores necessitam dimerizar (ver esquema na Figura 5) para tornarem-se funcionais (Xie et al., 2008).

Membros da subfamília ABCG estão envolvidos em processos de quimiorresistência em muitos eucariotos. Dentro desta subfamília, o mais conhecido é o transportador ABCG2 humano, chamado também de ABCP (placenta specific ABC), BCRP (breast cancer resistance protein) ou MXR (mitoxantrona resistance protein). Este transportador confere a células tumorais uma significativa resistência a diferentes fármacos como mitoxantrona, daunorrubicina, doxorrubicina, metotrexato, entre outros (Doyle et al., 1998; Ross et al., 1999; Scheffer et al., 2000; Shigeta et al., 2010). Em Leishmania, a superexpressão dos 
transportadores ABCG4 e ABCG6 confere resistência a fármacos hidrofóbicos como miltefosina, edelfosina e perifosina (Castanys-Muñoz et al., 2007, 2008).

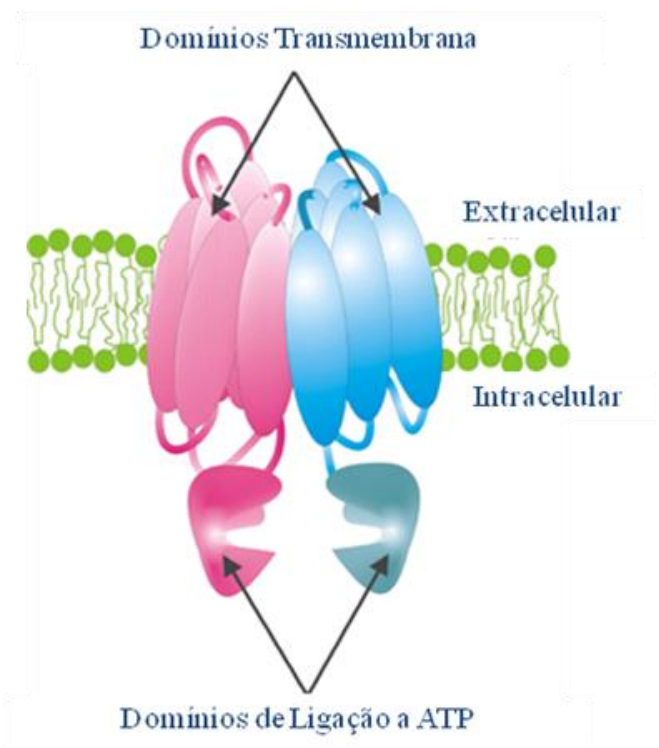

Figura 5 - Representação de um transportador $\mathrm{ABC}$ formado por dois meio-transportadores, que necessitam homodimerizar para formar uma proteína funcional.

Uma busca com o programa BLASTP mostrou elevada similaridade do transportador TcABCG1 com cinco transportadores da subfamília G (ABCG1-ABCG5) de humanos e de duas espécies de Leishmania (Tabela 2).

Tabela 2 - Similaridade por BLASTP do transportador TcABCG1 e membros da subfamília G de humanos e de duas espécies de Leishmania.

\begin{tabular}{cccccc}
\hline & \multicolumn{5}{c}{ Similaridade } \\
\cline { 2 - 5 } Organismo & ABCG1 & ABCG2 & ABCG3 & ABCG4 & ABCG5 \\
\hline $\begin{array}{c}\text { Homo sapiens } \\
\text { Leishmania } \\
\text { major }\end{array}$ & $28 \%$ & $29 \%$ & $28 \%$ & $28 \%$ & $26 \%$ \\
Leishmania infantum & $57 \%$ & $60 \%$ & $37 \%$ & $25 \%$ & - \\
\hline
\end{tabular}




\section{OBJETIVOS}

Os resultados obtidos por nosso grupo até o momento sugerem que o transportador TcABCG1 seja um dos elementos implicados na resistência natural a BZ em T. cruzi. Tendo em vista que BZ e NFX são compostos nitro-heterocíclicos e que Filardi e Brener (1987) observaram uma resistência análoga aos dois compostos em cepas de $T$. cruzi, é possível que TcABCG1 também atue na resistência a NFX.

Desta forma, o objetivo geral do presente estudo é verificar o envolvimento de TcABCG1 no fenótipo de resistência natural de T. cruzi a BZ. Para esta finalidade, iremos utilizar cepas suscetíveis e resistentes a BZ, criopreservadas em nosso banco.

Os objetivos específicos do estudo são:

1. Verificar a ação de inibidores de transportadores ABC na resistência a BZ;

2. Verificar se a superexpressão do gene $T c A B C G 1$ altera a suscetibilidade a BZ e NFX de uma cepa sensível;

3. Determinar o número de cópias do gene $T c A B C G 1$ em algumas cepas de $T$. cruzi cuja suscetibilidade a BZ é conhecida;

4. Como objetivo adicional, pretendemos caracterizar os genes de transportadores ABC presentes no genoma da cepa CL Brener, organismo de referência do projeto Genoma de T. cruzi. 


\section{MATERIAIS E MÉTODOS}

\subsection{Meios e Soluções}

- Meio LB - Bacto Triptona 1\%; Bacto Extrato de Levedura 0,5\%; $\mathrm{NaCl}$ 1\%, pH 7,0;

- Meio LB/ágar - Meio LB contendo 1,5\% ágar, pH 7,0;

- Meio LIT - $\mathrm{NaCl} 2 \% ; \mathrm{KCl}$ 0,2\%; $\mathrm{Na}_{2} \mathrm{HPO}_{4}$ anidro 4\%; Triptose 2,5\%; LIB 0,5\%; Glicose 0,4\%; Penicilina 0,02\%; Estreptomicina 0,02\%; Hemina 0,0025\%; Soro Fetal Bovino 10\%, $\mathrm{pH} \mathrm{7,4;}$

- Meio PBS 1x - Tampão Fosfato de Sódio 10 mM, pH 7,2; NaCl 150 mM, pH 7,4;

- Meio SOC - Glicose 20 mM; Bacto Triptona 2\%; Bacto Extrato de Levedura 0,5\%; $\mathrm{NaCl}$ $0,0585 \% ; \mathrm{KCl} \mathrm{0,0186 \% ,pH} \mathrm{7,0;}$

- SDS - Lauril Sulfato de Sódio;

- SSC 1x - NaCl 0,15 M; Citrato de Sódio 0,015 M, pH 7,0;

- Tampão de Eletroporação - Sacarose 272 mM, Tampão Fosfato de Sódio 7 mM, pH 7,2, $\mathrm{MgCl}_{2} 1 \mathrm{mM}$;

- TBE 1x - Tris-HCl 10 mM, pH 8,0; EDTA 1 mM, pH 8,0;

- TE - Tris-HCl 10 mM, pH 8,0; EDTA 1 mM, pH 8,0;

- Benznidazol - solução estoque 25 mM em DMSO;

- Nifurtimox (Bayer, Alemanha) - solução estoque 50 mM em DMSO.

\subsection{Cepas e culturas de $T$. cruzi}

As características das cepas utilizadas neste estudo quanto à sua classificação, origem geográfica e hospedeiro do qual foram isoladas são descritas na Tabela 4 (Resultados). Formas epimastigotas foram cultivadas em meio LIT (Liver Infusion Tryptose) suplementado com 10\% de Soro Fetal Bovino (SFB). O meio foi preparado segundo Castellani et al. (1967). As culturas foram mantidas a $28{ }^{\circ} \mathrm{C}$ sem agitação e repicadas na fase exponencial de crescimento. 


\subsection{Determinação da suscetibilidade a drogas}

\subsubsection{Determinação da suscetibilidade a $\mathrm{BZ}$}

Formas epimastigotas em fase exponencial de crescimento em meio LIT-10\% SFB foram distribuídas em placas de 24 poços numa densidade de $10^{7}$ células $/ \mathrm{ml}$ e expostas a diferentes concentrações de BZ $(0$ a $160 \mu \mathrm{M})$ por 72 horas a $28{ }^{\circ} \mathrm{C}$. Ao término deste período, a densidade celular das amostras foi determinada por contagem em câmara de Neubauer. A porcentagem de inibição do crescimento foi calculada em relação ao controle em ausência do composto. Os ensaios foram realizados em duplicata numa mesma placa e repetidos em dias diferentes. Para o cálculo da $\mathrm{CI}_{50}$, que corresponde à concentração de droga que inibe o crescimento celular em 50\%, os dados foram tratados com os programas Sigma Plot (versão 11) empregando o algoritmo Four Parametric Logistic. O cálculo da média e desvio-padrão da $\mathrm{CI}_{50}$ foi obtido com o programa Microsoft Office Excel (versão 2010).

\subsubsection{Determinação da suscetibilidade a NFX}

A suscetibilidade a NFX de formas epimastigotas foi determinada como descrito no item 3.3.1. As culturas foram expostas a diferentes concentrações do composto ( 0 a $80 \mu \mathrm{M})$ por 72 horas a $28^{\circ} \mathrm{C}$.

\subsection{Efeito de inibidores de transportadores $\mathrm{ABC}$ na suscetibilidade a $\mathrm{BZ}$}

Utilizamos como inibidores de transportadores $A B C$ verapamil, ciclosporina $A$ e fumitremorgin C. Inicialmente determinamos o efeito de cada inibidor na viabilidade dos parasitas $\left(\mathrm{CI}_{50}\right)$, utilizando o mesmo ensaio descrito acima. A seguir, a suscetibilidade a $\mathrm{BZ}$ foi determinada na presença de duas concentrações fixas de cada inibidor (doses inferiores à $\left.\mathrm{CI}_{50}\right)$.

\subsection{Manutenção de formas epimastigotas de T. cruzi - congelamento e descongelamento}

O congelamento de formas epimastigotas foi realizado quando as culturas estavam em fase exponencial de crescimento, preparando-se três tubos de criopreservação por cultura. Aproximadamente $2,4 \times 10^{8}$ células foram centrifugadas a $7000 \mathrm{rpm}$ por 7 minutos e 
ressuspensas em $3 \mathrm{ml}$ de meio LIT suplementado com SFB 10\% e Dimetilsufóxido (DMSO) 10\%. Alíquotas de $1 \mathrm{ml}$ foram distribuídas em tubos de criopreservação e mantidas em nitrogênio líquido. Para descongelar-se determinada cultura, o tubo foi imediatamente mantido a $37{ }^{\circ} \mathrm{C}$ por alguns minutos. $\mathrm{O}$ estado da cultura foi monitorado em microscópio óptico. Transferiu-se todo seu conteúdo para $10 \mathrm{ml}$ de meio LIT-10\% SFB, centrifugou-se a cultura a $7000 \mathrm{rpm}$ por 7 minutos e ressuspendeu-se o sedimento em $2 \mathrm{ml}$ de meio LIT-10\% SFB. A cultura foi então mantida em estufa a $28{ }^{\circ} \mathrm{C}$ por três dias, e, após este período, se elevou o volume de meio para $10 \mathrm{ml}$. A partir deste momento, a cultura passou a ser repicada regularmente ao ser atingida a fase exponencial de crescimento.

\subsection{Estocagem de formas epimastigotas para extração de DNA/RNA}

Para a extração de DNA e RNA total utilizaram-se, respectivamente, 3 x $10^{9}$ e 5 x $10^{8}$ formas epimastigotas. Os parasitas foram centrifugados a $7000 \mathrm{rpm}$ por 7 minutos a $4{ }^{\circ} \mathrm{C}$. O sedimento foi ressuspendido em $10 \mathrm{ml}$ de meio PBS 1x (Phosphate Buffer Saline), seguido de centrifugação a $7000 \mathrm{rpm}$ por 7 minutos a $4{ }^{\circ} \mathrm{C}$. O sobrenadante foi descartado. Adicionou-se 1,5 ml de meio PBS 1x, com nova centrifugação. O sobrenadante foi desprezado e o tubo mantido em gelo seco por 30 minutos, em freezer a $-80{ }^{\circ} \mathrm{C}$ por 24 horas e então estocado em nitrogênio líquido.

\subsubsection{Extração de DNA total de formas epimastigotas}

Para a extração de DNA, um sedimento contendo $3 \times 10^{9}$ epimastigotas foi ressuspendido em $10 \mathrm{ml}$ de PBS 1x e $500 \mu \mathrm{l}$ de Qiagen Proteinase K, proveniente do QIAamp Blood Maxikit (Qiagen). A extração foi conduzida de acordo com as instruções do fabricante. As amostras de DNA purificadas e eluídas em TE foram quantificadas por espectrofotometria a $260 \mathrm{~nm}$ e sua qualidade foi verificada por eletroforese em gel de agarose $0,8 \%$ corado com brometo de etídio.

\subsubsection{Extração de RNA total de formas epimastigotas}

Todos os materiais e soluções utilizados para a preparação de RNA foram tratados para remover-se RNAse. Materiais de vidro foram mantidos em forno a $180{ }^{\circ} \mathrm{C}$ por 4 horas e 
materiais de plástico foram autoclavados. A água utilizada foi acrescida de dietilpirocarobonato (DEPC) a $0,1 \%$ final, incubada a $37^{\circ} \mathrm{C}$ por 16 horas e autoclavada.

A extração do RNA total foi realizada com o reagente Trizol (Invitrogen). O sedimento de parasitas ( $5 \times 10^{8}$ células) foi ressuspendido em $1 \mathrm{ml}$ de Trizol frio e incubado por 5 minutos à temperatura ambiente. Um volume de $200 \mu \mathrm{l}$ de clorofórmio foi adicionado, com incubação por 3 minutos à temperatura ambiente seguido de centrifugação a $12000 \mathrm{rpm}$ por 15 minutos de 2 a $8{ }^{\circ} \mathrm{C}$. A fase aquosa (contendo o RNA) foi coletada e misturada com 0,5 $\mathrm{ml}$ de isopropanol e incubada por 10 minutos à temperatura ambiente, seguida de centrifugação nas condições anteriores. O sobrenadante foi descartado. O precipitado de RNA foi lavado com etanol 75\% gelado, seguido de nova centrifugação (10000 rpm por 5 minutos). O precipitado foi seco com bomba de vácuo e então ressuspendido em $35 \mu 1$ de água tratada com DEPC. Para eliminar a contaminação do RNA com DNA, a amostra foi tratada com 10U de DNAse (Promega) por 30 minutos a $37^{\circ} \mathrm{C}$, extraída com fenol, precipitada com etanol e analisada por eletroforese em gel de agarose $0,8 \%$ corado com brometo de etídio.

\subsection{Bactérias competentes}

Estoques de Escherichia coli DH5a (Bethesda Research Laboratories) competentes foram preparados de acordo com Sambrook e Russel (2001) e mantidos a $-80{ }^{\circ} \mathrm{C}$.

\subsection{Clonagem do gene $T c A B C G 1$}

\subsubsection{Amplificação do gene}

DNA genômico (100 ng) das cepas de T. cruzi foi amplificado em um meio reacional (volume final de $25 \mu \mathrm{l}$ ) contendo 0,625 U da enzima $P f u$ DNA polimerase (Fermentas), 2,5 $\mu \mathrm{l}$ do tampão 10x fornecido pelo fabricante, $2 \mathrm{mM}$ de $\mathrm{MgSO}_{4}, 200 \mathrm{mM}$ de dNTPs e $4 \mathrm{mM}$ dos iniciadores $T c A B C G 1 \mathrm{kbF}$ (5' - TCTAGAATGTCTTGCTGCCGAGC - 3', sítio de restrição para a enzima $X b a \mathrm{I}$ sublinhado) e $T c A B C G 1 \mathrm{kbR}$ (5'- CTCGAGCTAAAACTTTGTACG CGCG -3', sítio de restrição para a enzima Xhol sublinhado). Os iniciadores foram desenhados sobre as regiões que flanqueiam o gene TcABCG1 da cepa CL Brener (GenBank: Tc00.1047053508231.190). O DNA foi desnaturado por incubação a $95{ }^{\circ} \mathrm{C}$ durante 5 minutos. A amplificação foi realizada em equipamento Peltier Thermal Cycler PTC-200 MJ Research em 30 ciclos de três temperaturas: 1 minuto de desnaturação a $95{ }^{\circ} \mathrm{C}, 1,5$ minutos 
para anelamento dos iniciadores a $58{ }^{\circ} \mathrm{C}$ e 4 minutos de extensão a $72{ }^{\circ} \mathrm{C}$, seguidos de uma extensão final de 10 minutos. Os produtos de amplificação foram visualizados em gel de agarose $0,8 \%$ corado com brometo de etídio.

\subsubsection{Purificação do produto de PCR}

Os produtos da amplificação de $T c A B C G 1$ das cepas foram purificados a partir da PCR ou a partir do gel de agarose utilizando-se os kits PureLink ${ }^{T M}$ PCR Purification Kit (Invitrogen) ou HiYield ${ }^{T M}$ Gel/PCR DNA Mini Kit (Real Biotech), respectivamente. As amostras de DNA foram quantificadas por espectrofotometria a $260 \mathrm{~nm}$.

\subsubsection{Adição de adenina ao produto de PCR}

DNA polimerases termoestáveis com atividade proofreading, tal como a Pfu DNA Polimerase, geram fragmentos com pontas cegas ao final da amplificação por PCR. Os fragmentos gerados podem ser modificados utilizando-se um procedimento de ligação de adenina à extremidade 3' destes fragmentos e, assim, permitindo sua ligação ao vetor pGEMT Easy, que possui uma timina em sua extremidade 5'. Utilizamos este método conforme instruções do kit pGEM-T Easy Vector System (Promega). Ao realizarmos a clonagem através de vetor-T, não houve a necessidade de proceder-se a desfosforilação do vetor, e obteve-se, assim, baixo índice de vetor religado.

\subsubsection{Ligação ao vetor de clonagem}

A ligação do gene TcABCGl ao vetor pGEM-T Easy foi realizada conforme instruções do kit pGEM-T Easy Vector System (Promega). As reações foram feitas em $10 \mu 1$ de volume, contendo até $4 \mu \mathrm{l}$ de volume de inserto (respeitando-se a proporção inserto:vetor de 3:1), $5 \mu$ de Tampão Rapid Ligation 2x e $1 \mu 1$ da enzima T4 DNA ligase. As reações foram incubadas por 16 horas a $4^{\circ} \mathrm{C}$. 


\subsubsection{Transformação em bactérias competentes DH5 $\alpha$}

Alíquotas de $100 \mu \mathrm{l}$ de bactérias E. coli (cepa DH5 $\alpha$ ) competentes foram descongeladas do freezer a $-80{ }^{\circ} \mathrm{C}$ e a cada uma acrescentou-se $4 \mu \mathrm{l}$ da reação de ligação, seguindo-se de incubação por 20 minutos no gelo. Após este período, os tubos foram incubados a $42{ }^{\circ} \mathrm{C}$ por exatamente 50 segundos e recolocados no gelo por mais 2 minutos. A cada tubo acrescentou-se $260 \mu \mathrm{l}$ de meio SOC e os mesmos foram incubados a $37{ }^{\circ} \mathrm{C}$ sob agitação de 150 rpm por 1,5 horas. O volume total da suspensão bacteriana foi então semeado em placas de LB/ágar contendo $100 \mu \mathrm{g} / \mathrm{ml}$ de ampicilina, previamente tratadas com $50 \mu \mathrm{l}$ de X-gal $20 \mathrm{mg} / \mathrm{ml}$ (USB) e $100 \mu \mathrm{l}$ de IPTG $100 \mathrm{mM}$ (Gibco). Isso foi feito porque o plasmídeo pGEM-T Easy contém o gene da $\beta$-galactosidase, e as bactérias transformadas com o plasmídeo selvagem são capazes de degradar a X-gal como substrato e adquirem a cor azul. Se algum gene for inserido no polylinker do vetor e rompe o gene da $\beta$-galactosidase, as bactérias transformadas perdem a capacidade de degradar a X-gal e ficam brancas. Desta forma, podem-se distinguir por um método visual as colônias que contêm os insertos. Seguiuse com a incubação das placas por $16-20$ horas em estufa a $37{ }^{\circ} \mathrm{C}$ para seleção dos clones resistentes ao antibiótico. As colônias brancas foram então selecionadas para análise posterior.

\subsubsection{PCR de colônia}

Para confirmação e análise dos plasmídeos recombinantes, colônias bacterianas brancas foram inoculadas em $4 \mathrm{ml}$ de meio LB/amp e incubadas a $37{ }^{\circ} \mathrm{C}$ durante 16 horas, sob agitação constante de $200 \mathrm{rpm}$. A presença do inserto nos plasmídeos foi analisada por PCR de colônia. Pequena alíquota de cultura bacteriana $(1 \mu \mathrm{l})$ foi incubada em um meio reacional (volume final de $15 \mu \mathrm{l}$ ) contendo 0,375 U da enzima Taq DNA polimerase (Fermentas), 1,5 $\mu \mathrm{l}$ do tampão 10x fornecido pelo fabricante, $4 \mathrm{mM}$ de $\mathrm{MgCl}_{2}, 200 \mathrm{mM}$ de dNTPs e $4 \mathrm{mM}$ dos iniciadores $T c A B C G 616 \mathrm{~F}\left(5^{\prime}-\right.$ ACTTTGAGTCCATCGGATTCCCTTG - 3') e TcABCG616R (5' - CGGTAAAGACCCACCATCCAGTATA - 3'). Os iniciadores foram desenhados sobre as regiões que flanqueiam uma região de $616 \mathrm{pb}$, entre as posições 911 e 1527 do gene TcABCG1 da cepa CL Brener (Tabela 4). O DNA plasmidial foi desnaturado por incubação a $95{ }^{\circ} \mathrm{C}$ durante 10 minutos. A amplificação foi realizada em equipamento Peltier Thermal Cycler PTC-200 MJ Research em 30 ciclos de três temperaturas: 1 minuto de desnaturação a $95{ }^{\circ} \mathrm{C}, 1,5$ minutos para anelamento dos iniciadores a $58{ }^{\circ} \mathrm{C}$ e 1,5 minutos de 
extensão a $72{ }^{\circ} \mathrm{C}$, seguidos de uma extensão final de 9 minutos. Os produtos de amplificação foram visualizados em gel de agarose $0,8 \%$ corado com brometo de etídio.

\subsubsection{Purificação de DNA plasmidial}

A purificação de DNA plasmidial dos clones recombinantes confirmados pela PCR de colônia foi realizada a partir de 4 ou $250 \mathrm{ml}$ da cultura bacteriana, conforme instruções dos kits Pureyield Plasmid Miniprep System ou Pureyield Plasmid Maxiprep System (Promega), respectivamente. O DNA foi analisado por eletroforese em gel de agarose $0,8 \%$ contendo brometo de etídio e quantificado por espectrofotometria a $260 \mathrm{~nm}$.

\subsection{Sequenciamento do gene $T c A B C G 1$}

A reação de sequenciamento das duas fitas do gene TcABCG1 clonado em pGEMTEasy foi realizada com o kit Big Dye Terminator v.3.1 (Applied Biosystems) conforme protocolo do fabricante, em sequenciador ABI-PRISM® 3100 (IQ-USP). Para o sequenciamento, foram utilizados iniciadores específicos do plasmídeo - T7 e SP6 - e iniciadores desenhados para o gene $T c A B C G 1$, compostos por pares de iniciadores senso e anti-senso para amplificação de fragmentos de 616 e 492 pb (Tabela 4).

Tabela 3 - Características dos iniciadores utilizados no sequenciamento do gene TcABCG1.

\begin{tabular}{|c|c|c|c|}
\hline Iniciador & Localização & $\begin{array}{l}\text { Sequência } \\
\text { (5' para 3') }\end{array}$ & $\begin{array}{l}\text { Temperatura de } \\
\text { anelamento }\left({ }^{\circ} \mathrm{C}\right)\end{array}$ \\
\hline $\mathrm{T} 7$ & $\begin{array}{l}\text { Vetor pGEMT- } \\
\text { Easy }\end{array}$ & TAATACGACTCACTATAGGG & 53 \\
\hline SP6 & $\begin{array}{l}\text { Vetor pGEMT- } \\
\text { Easy }\end{array}$ & ATTTAGGTGACACTATAG & 55 \\
\hline$T c A B C G 616 \mathrm{~F}$ & $\begin{array}{c}911-935 \mathrm{nt}^{\mathrm{a}} \\
\text { (produto } 616 \mathrm{pb} \text { ) }\end{array}$ & ACTTTGAGTCCATCGGATTCCCTTG & 53 \\
\hline$T c A B C G 616 \mathrm{R}$ & $\begin{array}{c}1502-1526 \mathrm{nt}^{\mathrm{a}} \\
\text { (produto } 616 \mathrm{pb} \text { ) }\end{array}$ & CGG TAAAGACCCACCATCCAGTATA & 53 \\
\hline$T c A B C G 492 \mathrm{~F}$ & $\begin{array}{c}509-528 \mathrm{nt}^{\mathrm{a}} \\
\text { (produto } 492 \mathrm{pb} \text { ) }\end{array}$ & GCTTTTCGCTGCGCGTGAGG & 58 \\
\hline$T c A B C G 492 \mathrm{R}$ & $\begin{array}{c}974-1000 \mathrm{nt}^{\mathrm{a}} \\
\text { (produto } 492 \mathrm{pb} \text { ) }\end{array}$ & CCTTGGAAATTTCTGGATCTTGGAGCA & 58 \\
\hline
\end{tabular}

O DNA plasmidial de cada clone (200 ng) foi incubado em um meio reacional (volume final de $10 \mu \mathrm{l}$ ) contendo $1 \mu \mathrm{l}$ da solução de Big Dye, $2 \mu 1$ do tampão $5 \mathrm{x}$ fornecido 
pelo fabricante e $3,2 \mu \mathrm{M}$ dos iniciadores. O DNA foi desnaturado por incubação a $95{ }^{\circ} \mathrm{C}$ durante 3 minutos. A amplificação foi realizada em equipamento Peltier Thermal Cycler PTC-200 MJ Research em 35 ciclos de três temperaturas: 30 segundos de desnaturação a 95 ${ }^{\circ} \mathrm{C}, 15$ segundos para anelamento dos iniciadores (com temperatura específica para cada primer - ver Tabela 4) e 4 minutos de extensão a $60{ }^{\circ} \mathrm{C}$.

As reações de sequenciamento, realizadas em tubos de microcentrífuga, foram transferidas para placa de 96 poços seguidas pela precipitação por glicogênio. Aos $10 \mu 1$ de cada reação foram adicionados $17 \mu \mathrm{l}$ de cocktail de precipitação gelado (etanol 92,5\%, $\mathrm{NaOAc} 100 \mathrm{mM}$ pH 5,2, glicogênio $36 \mu \mathrm{g} / \mathrm{ml}$ ). A placa foi mantida em gelo por 15 minutos e centrifugada a $4000 \mathrm{rpm}$ por 20 minutos à temperatura ambiente, descartando-se o excesso de cocktail por inversão da placa e um pulso de $1000 \mathrm{rpm}$ com a placa invertida. Adicionou-se $50 \mu \mathrm{l}$ de etanol 70\% gelado por poço, repetindo-se a centrifugação (10 minutos) e drenagem da placa, conforme descrito anteriormente. A placa foi secada a $95{ }^{\circ} \mathrm{C}$ em termociclador por 1 minuto, selada, protegida da luz e mantida a $-20{ }^{\circ} \mathrm{C}$ até o momento de ser levada aos procedimentos de leitura no sequenciador.

Foram sequenciados no mínimo seis clones de cada cepa. As sequências individuais de cada gene foram montadas pelo programa BioEdit a partir dos contigs formados pelas sequências parciais de cada gene específico. O clone 1 de cada cepa foi aquele escolhido para a clonagem no vetor de expressão.

\subsection{Transfecção do gene TcABCG1 em T. cruzi}

\subsubsection{Liberação do gene TcABCG1 do vetor de clonagem}

O gene TcABCG1 de diferentes cepas, clonado em pGEM-T Easy, foi liberado por dupla digestão com as enzimas de restrição XbaI e XhoI a $37^{\circ} \mathrm{C}$ por 16 horas. A reação de digestão foi interrompida pela adição de tampão de amostra e submetida à eletroforese em gel de agarose $0,7 \%$ corado com brometo de etídio. O inserto de DNA foi visualizado em transiluminador sob luz ultravioleta e a banda foi excisada com bisturi. O DNA foi purificado conforme descrito no item 3.8.2. 


\subsubsection{Clonagem do gene TcABCG1 no vetor pROCKNeo}

O gene TcABCG1 foi ligado ao vetor pROCKNeo (DaRocha et al., 2004), digerido com as enzimas de restrição $X b a \mathrm{I}$ e $X h o \mathrm{I}$, na proporção inserto:vetor de 3:1, conforme descrito no item 3.8.4. A transformação de bactérias competentes com o plasmídeo recombinante foi realizada conforme descrito no item 3.8.5. As bactérias foram semeadas em LB/ágar contendo ampicilina. Os plasmídeos recombinantes foram identificados por PCR de colônia (item 3.8.6) e sequenciamento (item 3.9). Para os experimentos de transfecção, 100 $\mu \mathrm{g}$ de DNA plasmidial foram digeridos com $10 \mu \mathrm{l}$ (unidades não fornecidas pelo fabricante) de FastDigest NotI (Fermentas) por 16 horas a $37{ }^{\circ} \mathrm{C}$. O DNA foi purificado por precipitação com isopropanol (Sambrook e Russel, 2001), e quantificado por espectrofotometria a $260 \mathrm{~nm}$.

\subsubsection{Transfecções em T. cruzi}

Para cada transfecção foram utilizadas $2 \times 10^{8}$ formas epimastigotas de CL Brener. Os parasitas foram centrifugados a $7000 \mathrm{rpm}$ por 7 minutos a $4{ }^{\circ} \mathrm{C}$ e ressuspensos em $10 \mathrm{ml}$ de PBS 1x estéril. Em seguida, foram novamente centrifugados e ressuspensos em pequeno volume (inferior ao necessário para a eletroporação) de tampão de eletroporação (ver item 3.1), sendo mantidos em gelo. Determinou-se a densidade celular e acrescentou-se volume de tampão de eletroporação necessário para se obter $5 \times 10^{8}$ células $/ \mathrm{ml}$. Transferiu-se $0,4 \mathrm{ml}$ da suspensão para cada cubeta de 0,2 cm (BioRad) resfriada em gelo e adicionou-se $50 \mu \mathrm{g}$ de DNA plasmidial linearizado e purificado (item 3.10.2) em $50 \mu \mathrm{l}$ de $\mathrm{H}_{2} \mathrm{O}$. Como controle negativo, os parasitas foram incubados com $50 \mu \mathrm{lde} \mathrm{H}_{2} \mathrm{O}$. Para medir a eficiência de transfecção, uma alíquota de parasitas foi incubada com o plasmídeo pTREXGFP (DaRocha et al., 2004). As amostras foram mantidas em gelo por 10 minutos e eletroporadas usando o BioRad Cell Porator, com 2 pulsos sucessivos de 200V a $250 \mu \mathrm{F}$. Os parasitas foram mantidos à temperatura ambiente por 5 minutos e transferidos para frascos com $10 \mathrm{ml}$ de meio LIT-10\% SBF. Nas amostras transfectadas com pROCKNeo, $200 \mu \mathrm{g} / \mathrm{ml}$ de neomicina foi adicionado ao meio de cultura. A viabilidade/sobrevivência das células foi monitorada em microscópio de fase imediatamente após eletroporação. Os parasitas foram incubados a $28^{\circ} \mathrm{C}$. A eficiência de transfecção foi monitorada após 24 horas. As culturas foram repicadas periodicamente. 


\subsection{Southern Blot}

Após digestão de $5 \mu \mathrm{g}$ de DNA com diferentes enzimas de restrição (New England Biolabs) por 16 horas a $37{ }^{\circ} \mathrm{C}$, o DNA foi submetido à eletroforese em gel de agarose $1 \%$. Após eletroforese, o DNA foi depurinado com $\mathrm{HCl}$ 0,2 M por 10 minutos, desnaturado duas vezes com $\mathrm{NaOH}$ 0,5 M por 15 minutos, e neutralizado com $\mathrm{NaCl}$ 1,5 M, Tris- $\mathrm{HCl}$ 0,5 M, pH 7,2 e EDTA $1 \mathrm{mM}$ por 30 minutos (duas vezes). O DNA foi transferido para membranas de Nylon (Hybond-N, Amersham Pharmacia) em 20x SSC por 16 horas e fixado por exposição à luz UV por 5 minutos e aquecimento a $80{ }^{\circ} \mathrm{C}$ por 2 horas. Em seguida, as membranas foram hibridizadas com sondas derivadas dos genes de interesse, marcadas com $\left[\alpha-\mathrm{P}^{32}\right] \mathrm{dATP}$.

\subsection{Obtenção de sondas radioativas e condições de hibridização}

\subsubsection{Marcação por random primer extension}

Para a incorporação de nucleotídeos radioativos, sondas de DNA foram marcadas com

$\left[\alpha-\mathrm{P}^{32}\right]$ dATP com o kit de marcação de DNA utilizando random primers (Invitrogen). O equivalente a $150 \mathrm{ng}$ de DNA foi diluído para um volume apropriado de água e desnaturado em banho fervente por 5 minutos. O tubo contendo o DNA foi transferido para o gelo, adicionando-se em seguida: $20 \mu \mathrm{M}$ de dTTP, dCTP, dGTP e [ $\left.\alpha-\mathrm{P}^{32}\right] \mathrm{dATP}(50 \mu \mathrm{Ci})$, tampão de mistura do random primer (Hepes 0,67 mM, Tris- $\mathrm{HCl} 0,17 \mathrm{mM}, \mathrm{MgCl}_{2} 17 \mathrm{mM}, \beta-$ mercaptoetanol $33 \mathrm{mM}$, BSA $1,33 \mathrm{mg} / \mathrm{ml}$, hexanucleotídeos iniciadores $18 \mathrm{DO}_{260}$ unidades/ml, pH 6,8) e $3 \mathrm{U}$ de Klenow em volume final de reação de $50 \mu 1$. A reação desenvolveu-se à temperatura ambiente por 3 horas e foi interrompida pela adição de tampão de parada (EDTA 0,5 M, pH 8,0). A sonda foi purificada de nucleotídeos não incorporados por passagem em coluna Sephadex G50 (Sambrook e Russel, 2001). Para a medida de incorporação, foi feita contagem em contador de cintilação líquida.

\subsubsection{Hibridização de sondas radioativas com ácidos nucléicos imobilizados}

As membranas contendo DNA imobilizado foram pré-hibridizadas em forno HyBaid a $60{ }^{\circ} \mathrm{C}$ por 90 minutos com $10 \mathrm{ml}$ de tampão de hibridização (Ficol 01\%, PVP 0,05\%, EDTA 1 mM, SSC 3x, SDS $0,1 \%$ e DNA de esperma de salmão $100 \mu \mathrm{g} / \mathrm{ml}$ ). Esta solução foi 
substituída por $10 \mathrm{ml}$ de tampão de hibridização contendo a sonda desnaturada. A hibridização ocorreu por 16 horas a $60{ }^{\circ} \mathrm{C}$.

\subsubsection{Lavagem das membranas}

Após hibridização, as membranas de Southern Blot foram lavadas sequencialmente a $60{ }^{\circ} \mathrm{C}$ nas seguintes condições: 2 lavagens em solução SSC 3x, SDS 0,1\% por 15 minutos; e 2 lavagens com solução SSC 1x, SDS $0,1 \%$ por 30 minutos. Caso houvesse necessidade de maior estringência de hibridização, as membranas foram lavadas 1 ou 2 vezes com SSC $0,1 \mathrm{x}$, SDS $0,1 \%$ por 30 minutos. As imagens provenientes das membranas foram coletadas em Phosphor Screens (Kodak), expostas por 24 horas e escaneadas com o aparelho Storm (Molecular Dynamics). A análise densitométrica do sinal radioativo foi obtida com o programa ImageQuant Molecular Dynamics. As imagens também foram obtidas por exposição de cada membrana a dois Phosphor Screens intensificadores (Kodak) em cassetes apropriados (Fuji Film) por 24-72 horas (o tempo de exposição variou conforme a intensidade das bandas observadas na imagem obtida pelo Storm) a $-80{ }^{\circ} \mathrm{C}$.

\subsubsection{Desibridização das membranas}

Para reutilização das membranas de Southern Blot, as sondas foram retiradas por lavagem com SSC $0,1 \mathrm{x}$, SDS $0,5 \%$ a $90{ }^{\circ} \mathrm{C}$ por 60 minutos. Para verificar a eficiência do processo, as membranas foram expostas a Phosphor Screens e reveladas no Storm.

\subsection{PCR em tempo real para determinação do número de cópias do gene $T c A B C G 1$}

O número de cópias do gene $T c A B C G 1$ foi estimado por PCR em tempo real seguindo abordagens descritas anteriormente (Lee et al., 2008; Schmidt e Parrott, 2001; Song et al., 2002). O plasmídio pGEM-T contendo o gene TcABCG1 de CL Brener foi utilizado para construir uma curva padrão representando $10^{0}$ a $10^{7}$ cópias do gene. Os valores de $\mathrm{C}_{\mathrm{T}}$ foram plotados contra o logaritmo do número de cópias. Amplificações por PCR em tempo real foram realizadas com $0,1 \mathrm{ng}$ de DNA genômico das cepas. Estas reações foram feitas em paralelo com as reações da curva padrão. Os valores de $\mathrm{C}_{\mathrm{T}}$ foram usados para o cálculo do número de cópias do gene. A quantidade de DNA das cepas utilizada nas amplificações foi convertida em número de genomas, utilizando-se o tamanho do genoma de estimado para CL 
Brener (110 Mb) (El-Sayed et al., 2005) e a informação de que esta cepa possui duas cópias de TcABCG1 por genoma diplóide (TriTrypDB, 2011). Os experimentos foram realizados em triplicata.

\subsection{RT-PCR em tempo real}

Os iniciadores foram desenhados sobre a sequência nucleotídica completa dos genes TcABCG1 e TcGAPDH (Gliceraldeído-3-fosfato desidrogenase de T. cruzi, utilizado como gene normalizador), com o auxílio do programa Primer Express (Applied Biosystems), que os desenha com as características necessárias para os experimentos de PCR em tempo real. As sequências dos iniciadores que originam produtos de 76 pb são TcABCG76F (5'GTGAACGCAAACGCACAAGTA-3') e TcABCG76R (5'-TTGCTGGATGAACCCA CCTC-3'); e TcGAPDH76F (5'-GACGACACGCCCATGTTTG-3') e TcGAPDH76R (5'ACGAGGCGTTGGAGACGAT-3'). O RNA utilizado nos ensaios foi obtido conforme descrito no item 3.6.2.

\subsubsection{PCR convencional}

Para averiguar a adequação dos oligonucleotídeos iniciadores desenhados, realizamos uma PCR convencional com 100 ng de DNA genômico de CL Brener e cada par de iniciadores. Ainda, para comprovar a ausência de DNA contaminante nas amostras de RNA tratadas com DNAse, realizamos também uma PCR convencional com RNA de cada cepa e os iniciadores. Neste caso, esperaríamos não obter nenhum produto de amplificação.

Para cada reação, utilizamos amostra de DNA ou RNA, 2,5 mM de mix de dNTP, 10 pmoles de cada oligonucleotídeo iniciador (específico para cada gene), 1U de Taq DNA polimerase (GO Taq) e $5 \mu 1$ de tampão de reação $5 \mathrm{x}$ fornecido pelo kit. A PCR foi realizada nas seguintes condições: $94{ }^{\circ} \mathrm{C}$ por 4 minutos; passo 2: $94{ }^{\circ} \mathrm{C}$ por 1 minuto; passo $3: 58{ }^{\circ} \mathrm{C}$ por 1 minuto; passo $4: 72{ }^{\circ} \mathrm{C}$ por 1 minuto. Repetiu-se desde o passo 2 até o passo 4 por 33 vezes. Passo 5: $94{ }^{\circ} \mathrm{C}$ por 1 minuto; passo $6: 58{ }^{\circ} \mathrm{C}$ por 1 minuto; passo 7: $72{ }^{\circ} \mathrm{C}$ por 10 minutos e para finalizar, passo: $4{ }^{\circ} \mathrm{C}$ por tempo indeterminado. Para todas as reações foi incluído um controle negativo (sem DNA ou RNA). 


\subsubsection{Síntese da primeira fita de cDNA}

Para a síntese da primeira fita de cDNA foi utilizado $5 \mu \mathrm{g}$ de RNA total tratado com DNAse, 1,5 $\mu \mathrm{l}$ de dNTP mix 10 mM, $2 \mu \mathrm{g}$ de hexâmeros randômicos e o volume da reação foi completado a $19 \mu \mathrm{l}$ com água. A solução foi aquecida por 5 minutos a $65{ }^{\circ} \mathrm{C}$ e imediatamente colocada em gelo. A esta reação foi adicionado $6 \mu 1$ de tampão 5x; $3 \mu 1$ de DTT 0,1 M e $1 \mu 1$ de inibidor de RNAse. A amostra foi aquecida por 2 minutos a $42{ }^{\circ} \mathrm{C}$ e, após este período, foram adicionadas $20 \mathrm{U}$ de Transcriptase Reversa Super Script II (Invitrogen), incubando-se a $25{ }^{\circ} \mathrm{C}$ por 10 minutos e $42{ }^{\circ} \mathrm{C}$ por 50 minutos. A reação foi interrompida por aquecimento a $70{ }^{\circ} \mathrm{C}$ por 15 minutos e a amostra foi diluída 4 vezes com água livre de nucleases.

\subsubsection{Síntese da segunda fita de cDNA e PCR em tempo real}

Para a síntese da segunda fita de cDNA e consequente incorporação do corante Syber Green, foram utilizados $6 \mu \mathrm{l}$ de cDNA simples fita, 2 pmoles de cada oligonucleotídeo iniciador (específico para cada gene testado) e $10 \mu 1$ de Syber Green, num volume final de 20 $\mu 1$. A reação foi desenvolvida no equipamento Mastercycler Realplex (Eppendorf), nas seguintes condições: $95{ }^{\circ} \mathrm{C}$ por 2 minutos, 40 ciclos de $95{ }^{\circ} \mathrm{C}$ por 15 segundos, $55^{\circ} \mathrm{C}$ por 15 segundos e $68^{\circ} \mathrm{C}$ por 20 segundos.

\subsubsection{Teste da eficiência de amplificação}

Para testar a eficiência dos primers, uma série de diluições de $10^{0}$ até $10^{7}$ cópias molares de um plasmídio contendo o gene alvo ou inserto de GAPDH de T. cruzi foram utilizados para construir as curvas-padrão de amplificação. Os valores de $\mathrm{C}_{\mathrm{T}}($ Cycle Threshold) foram plotados contra o logaritmo de suas concentrações de cópias iniciais. As curvas-padrão foram geradas para cada primer por uma linha de regressão dos pontos plotados no gráfico. A partir da inclinação de cada curva, a eficiência de amplificação de PCR (E) foi calculada (Lee et al. 2008). A eficiência da amplificação dos genes alvo e de referência foi calculada similarmente e utilizada para calcular o $\Delta \mathrm{C}_{\mathrm{T}}$. 


\subsubsection{Análises dos dados}

Cada ensaio foi realizado em triplicata. Os dados foram analisados usando o 7300 System Software (Applied Biosystems) e normalizados para os valores do housekeeping gene $G A P D H$. Para cada amostra foi obtido o $\mathrm{C}_{\mathrm{T}}$, que é definido com o ciclo onde a fluorescência se encontra estatisticamente acima do background. Foi obtida a média dos $\mathrm{C}_{\mathrm{T}}$ das triplicatas e seu desvio-padrão.

Uma vez que a expressão do gene é analisada em relação ao controle interno (GAPDH), foi então calculado o $\Delta \mathrm{C}_{\mathrm{T}}$, ou seja, a diferença entre as médias do $\mathrm{C}_{\mathrm{T}}$ de cada amostra e a média do $\mathrm{C}_{\mathrm{T}}$ do controle interno (GAPDH). Posteriormente, foi calculado o $\Delta \Delta \mathrm{C}_{\mathrm{T}}$, que consiste na diferença do $\Delta \mathrm{C}_{\mathrm{T}}$ de cada amostra em relação ao $\Delta \mathrm{C}_{\mathrm{T}}$ da amostra de referência (cepa CL Brener não transfectada). Os $\Delta \Delta \mathrm{C}_{\mathrm{T}}$ encontrados refletem as diferenças de abundância de produto entre os ciclos, mas não refletem diretamente a diferença de produto entre as amostras. Para calcular a razão relativa dos transcritos de cada gene em relação à abundância de transcritos na cepa de referência, foi aplicada a fórmula $2^{-\Delta \Delta \mathrm{CT}}$, que parte do princípio de que a cada ciclo da PCR a quantidade de produto dobra, sendo então necessário contemplar que o ganho de cada ciclo (2 vezes) seja elevado à potência do inverso de $\Delta \Delta \mathrm{C}_{\mathrm{T}}$ (Pfaffl, 2001). A análise estatística dos resultados de comparação da abundância de transcritos entre as cepas foi obtida com o programa Sigma Plot com os dados de duas réplicas biológicas.

\subsection{Identificação e caracterização de genes de $T$. cruzi para transportadores ABC}

Genes de CL Brener anotados como putative ABC transporter foram identificados no banco de dados TriTrypDB (TriTrypDB, 2011). Genes ABC hipotéticos adicionais foram obtidos por buscas com o programa BLAST P (versão 2.2.25+) (Altschul et al., 1997) no banco de dados do genoma de T. cruzi do NCBI (Johnson et al., 2008), utilizando-se como entrada (query) sequências da assinatura $\mathrm{ABC}$ dos putativos transportadores $\mathrm{ABC}$ de $T$. cruzi. As ORFs (Open Reading Frames) das sequências resultantes desta busca com E-value menores que $10^{-5}$ foram selecionadas e avaliadas no banco de estruturas de proteínas do NCBI (Wang et al., 2007) pela busca de domínios e motivos do transportador ABC e no banco de dados do programa Pfam (Bateman et al., 2004; Finn et al., 2010) pela confirmação da presença da assinatura $\mathrm{ABC}$ em cada sequência. Os dois haplótipos de um mesmo gene (Esmeraldo e Não-Esmeraldo) foram identificados, assim como possíveis genes ortólogos, 
através do programa OrthoMCL (Chen et al., 2006; Li et al., 2003), de outras espécies de Trypanosoma e Leishmania. A estrutura de cada proteína $\mathrm{ABC}$ hipotética, referente à localização cromossômica, localização celular, número e disposição dos domínios, foi analisada com o TriTrypDB e banco de estrutura de proteínas PDB (Protein Data Bank) (Berman et al., 2000).

\subsection{Análises filogenéticas e classificação dos transportadores ABC de T. cruzi}

As sequências de aminoácidos dos NBDs de membros ABC hipotéticos de CL Brener e as sequências de um representante de cada uma das subfamílias A a G de humanos (Sheps et al., 2004) e subfamília H de Leishmania major (Leprohon et al., 2006) foram alinhadas com o programa CLUSTALW (Thompson et al., 1994) e submetidas à checagem manual no programa BioEdit (Biological Sequence Alignment Editor for Windows) (Hall, 1999). Quando uma proteína ABC completa apresentava dois NBDs, cada domínio foi tratado independentemente nas análises. As genealogias foram determinadas a partir do alinhamento múltiplo montado com a exclusão de regiões com lacunas (gaps), contendo principalmente as porções correspondentes às regiões Walker $\mathrm{A}$, Walker $\mathrm{B}$ e assinatura $\mathrm{ABC}$.

O alinhamento múltiplo foi utilizado para a reconstrução filogenética utilizando-se o programa PAUP (versão 4.0b10) (Swofford, 2001). A reconstrução foi realizada utilizando-se os métodos de distância (Neighbor-Joining, NJ) (Saitou e Nei, 1987) e de máxima parcimônia (descrito por Fitch, 1971), com o algoritmo de busca heurística (por stepwise addition, que consiste na adição seqüencial de táxons, os quais são inseridos sempre na posição que minimiza o incremento no comprimento da árvore). Para a visualização das árvores geradas foi usado o programa TreeView (versão 1.6.6) desenvolvido por Page (1996).

De acordo com a posição das sequências nos ramos das árvores e sua comparação com a posição das sequências de ABCs humanos (subfamílias A a G) e de Leishmania major (subfamília $\mathrm{H}$ ), as proteínas $\mathrm{ABC}$ de $T$. cruzi puderam ser classificadas nas respectivas subfamílias. Para esta finalidade seguiram-se as recomendações da HUGO Gene Nomenclature Committee para genes ABC (HUGO, 2011; Ishikawa et al., 2000). A confiabilidade desta classificação foi reforçada pela análise da porcentagem de similaridade entre membros de uma mesma subfamília de T. cruzi com representantes de subfamílias das outras duas espécies (Homo sapiens sapiens e L. major) escolhidas como referência. 


\section{RESULTADOS}

\subsection{Determinação da suscetibilidade a BZ em cepas de $T$. cruzi}

As características das cepas utilizadas neste estudo são descritas na Tabela 4. A suscetibilidade a BZ foi determinada conforme descrito em Materiais e Métodos e o valor da $\mathrm{CI}_{50}$ consta da Tabela 4. Nas seis cepas analisadas, verificamos que a $\mathrm{CI}_{50}$ para $\mathrm{BZ}$ variou de $13,2 \pm 0,8$ a $58,6 \pm 5,7 \mu \mathrm{M}$. A suscetibilidade a BZ destas cepas foi previamente determinada em modelos experimentais infectados e tratados (Filardi e Brener, 1987). De acordo com estes autores, as cepas foram classificadas em resistentes (taxas de cura $<33 \%$ ), parcialmente suscetíveis (taxas de cura 33\% a 66\%) ou suscetíveis (taxas de cura > 66\%). Para efeito de comparação, na Tabela 4 apresentamos a porcentagem de cura descrita por Filardi e Brener (1987).

Tabela 4 - Características de cepas de T. cruzi utilizadas no estudo.

\begin{tabular}{lcccc}
\hline Cepa & $\begin{array}{c}\text { DTU } \\
\text { T. } \text { cruzi }\end{array}$ & Hospedeiro/Origem & $\begin{array}{c}\mathbf{C I}_{\mathbf{5 0}}{ }^{\mathbf{c}} \mathbf{B Z}(\boldsymbol{\mu M}) \\
(\mathbf{m e ́ d i a} \pm \mathbf{d p})^{\mathbf{d}}\end{array}$ & $\boldsymbol{\%}^{\text {\% de cura }}{ }^{\mathrm{e}}$ \\
\hline CL Brener & TcVI & T. infestans/Rio Grande do Sul & $13,2 \pm 0,8$ & 100 \\
Berenice 62 & TcII & Humano/Minas Gerais & $14,6 \pm 3,6$ & 93 \\
VL10 & TcII & Humano/Minas Gerais & $30,4 \pm 6,9$ & 27 \\
Colombiana & TcI & Humano/Colômbia & $58,6 \pm 5,7$ & 7 \\
YuYu & TcI & T. infestans/Bahia & $40,5 \pm 1,8$ & 0 \\
Silvio X10 cl1 & TcI & Humano/Pará & $26,1 \pm 2,5$ & 69 \\
\hline
\end{tabular}

\footnotetext{
${ }^{a}$ As cepas CL Brener e Silvio X10 cl1 são clones.

${ }^{\mathrm{b}}$ Segundo a nova nomenclatura (Zingales et al., 2009).

${ }^{\mathrm{C}} \mathrm{CI}_{50}$ : concentração efetiva de $\mathrm{BZ}$ que diminui o número de parasitas viáveis em $50 \%$.

${ }^{\mathrm{d}}$ Cada valor representa média e desvio-padrão $(\mathrm{dp})$ de duplicatas de pelo menos dois experimentos independentes.

${ }^{\text {e}}$ Porcentagem de cura determinada em modelo experimental (Filardi e Brener, 1987).
}

A análise dos dados indica haver uma concordância entre o grau de suscetibilidade a $\mathrm{BZ}$ determinado in vitro para formas epimastigotas (valor da $\mathrm{CI}_{50}$ ) e o sucesso terapêutico determinado in vivo. As três cepas consideradas resistentes por Filardi e Brener (VL10, Colombiana e $\mathrm{YuYu}$ ) apresentam $\mathrm{CI}_{50}$ para $\mathrm{BZ}$ que varia de $30,4 \pm 6,9$ e 58,6 $\pm 5,7 \mu \mathrm{M}$. As duas cepas consideradas suscetíveis (CL Brener e Berenice 62) apresentam $\mathrm{CI}_{50}$ para BZ da ordem de $14 \mu \mathrm{M}$. Uma possível discrepância refere-se à cepa Silvio, que foi considerada 
suscetível por Filardi e Brener (1987) e que em nossos ensaios apresentou um valor de $\mathrm{CI}_{50}$ para BZ de 26,1 $\pm 2,5 \mu \mathrm{M}$ (Tabela 4). Devemos ressaltar, no entanto, que em nosso estudo utilizamos um clone da cepa Silvio (Silvio X10 cl1) que pode ter uma suscetibilidade a BZ diferente da cepa da qual derivou. Desta forma, neste trabalho a cepa Silvio X10 cl1 será considerada resistente a BZ e denominada apenas Silvio.

\subsection{Efeito de inibidores de transportadores $\mathrm{ABC}$ na suscetibilidade a BZ}

A fim de obter evidências adicionais para o envolvimento de transportadores $\mathrm{ABC}$ no fenótipo de resistência a BZ em T. cruzi, investigamos o efeito de três inibidores conhecidos de transportadores $\mathrm{ABC}$ : verapamil, ciclosporina A e fumitremorgin $\mathrm{C}$ (revisto por Doyle e Ross, 2003; Ejendal e Hrycyna, 2004; Hiroyuki e Sugiyama, 2007; Qadir et al., 2005; Robey et al., 2008). Na escolha dos inibidores, priorizamos aqueles cuja ação tivesse sido comprovada em diferentes subfamílias de ABC. Verapamil é considerado um inibidor preferencial de $\mathrm{ABCB}$, podendo, porém, também atuar nas subfamílias $\mathrm{ABCC}$ e $\mathrm{ABCG}$, que conferem fenótipo de resistência a drogas (Robey et al., 2008). A ciclosporina A é um inibidor preferencial de $\mathrm{ABCB}$ e $\mathrm{ABCC}$ e não inibe transportadores $\mathrm{ABCG}$ (Ejendal e Hrycyna, 2004; Qadir et al., 2005). O efeito inibitório de fumitremorgin C em uma classe de transportadores ABCG de células humanas foi estabelecido (revisto em Kusuhara e Sugiyama, 2007).

Inicialmente determinamos a $\mathrm{CI}_{50}$ de cada inibidor (Tabela 5) no crescimento das cepas CL Brener (sensível a BZ) e VL10 (resistente a BZ), utilizando a mesma abordagem experimental empregada para a análise da suscetibilidade a BZ.

Tabela 5 - Efeito de inibidores de transportadores $\mathrm{ABC}$ no crescimento de formas epimastigotas da cepa CL Brener e VL10.

\begin{tabular}{lcc}
\hline Inibidor & \multicolumn{2}{c}{$\mathbf{C I}_{\mathbf{5 0}}(\boldsymbol{\mu M})^{\mathbf{a}}(\mathbf{m e ́ d i a} \pm \mathbf{d p})^{\mathbf{b}}$} \\
\cline { 2 - 3 } & $\mathbf{C L}$ Brener & $\mathbf{V L 1 0}$ \\
Verapamil & $32,1 \pm 1,6$ & $56,1 \pm 2,3$ \\
Ciclosporina A & $1,1 \pm 0,5$ & $1,3 \pm 0,2$ \\
\hline entração efetiva do composto que diminui o número de parasitas viáveis em 50\%. \\
representa média e desvio-padrão $(\mathrm{dp})$ das duplicatas de pelo menos dois experimentos
\end{tabular}

${ }^{\mathrm{a}} \mathrm{CI}_{50}$ : concentração efetiva do composto que diminui o número de parasitas viáveis em $50 \%$.

${ }^{\mathrm{c} C} \mathrm{Cada}$ valor representa média e desvio-padrão (dp) das duplicatas de pelo menos dois experimentos independentes. 
Para fumitremorgin $\mathrm{C}$ (FTC) não foi possível determinar a $\mathrm{CI}_{50}$, pois não houve inibição do crescimento das culturas expostas desde 2,5 até $10 \mu \mathrm{M}$ do composto por 72 horas a $28^{\circ} \mathrm{C}$. Não foi possível aumentar a concentração de FTC em função de sua solubilidade em DMSO. Concentrações maiores levariam a uma dose de DMSO tóxica para os parasitas. Dados da literatura indicam que FTC atua como inibidor de transportadores ABCG humanos em concentrações de até $10 \mu \mathrm{M}$ (Susanto et al., 2008; Tiwari et al., 2009).

Tabela 6 - Efeito de verapamil na suscetibilidade a BZ $\left(\mathrm{CI}_{50}\right)$ em cepas de $T$. cruzi.

\begin{tabular}{lccccc}
\hline & $\mathbf{0} \boldsymbol{\mu M}$ verapamil & \multicolumn{2}{c}{$\mathbf{2 0} \boldsymbol{\mu M}$ verapamil $^{\mathrm{a}}$} & \multicolumn{2}{c}{$\mathbf{3 0} \boldsymbol{\mu M}$ verapamil $^{\mathbf{a}}$} \\
\cline { 2 - 6 } Cepa & $\mathrm{CI}_{50} \mathrm{BZ}$ & $\mathrm{CI}_{50} \mathrm{BZ}$ & Inibição $^{\mathrm{b}}$ & $\mathrm{CI}_{50} \mathrm{BZ}$ & Inibição $^{\mathrm{b}}$ \\
& $(\mu \mathrm{M})$ & $(\mu \mathrm{M})$ & $(\%)$ & $(\mu \mathrm{M})$ & $(\%)$ \\
\hline CL Brener & 13,2 & 11,1 & 16 & 6,7 & 51 \\
Berenice 62 & 9,4 & 7,6 & 19 & 4,6 & 51 \\
VL10 & 23,6 & 19,6 & 17 & 11,6 & 51 \\
Colombiana & 50,2 & 31,2 & 38 & 24,0 & 52 \\
\hline
\end{tabular}

${ }^{\mathrm{a}}$ Concentrações abaixo da $\mathrm{CI}_{50}$ do verapamil.

${ }^{\mathrm{b}}$ Porcentagem de inibição da $\mathrm{CI}_{50}$ de $\mathrm{BZ}$ em relação à $\mathrm{CI}_{50}$ da cultura controle em ausência de verapamil. Média de dois experimentos independentes.

Em seguida, determinamos o efeito de duas concentrações fixas de verapamil (20 e 30 $\mu \mathrm{M}$ ), concentrações abaixo de sua $\mathrm{CI}_{50}$, na suscetibilidade a $\mathrm{BZ}$ em quatro cepas de $T$. cruzi. Formas epimastigotas foram incubadas com diferentes concentrações de BZ, em ausência ou em presença das duas concentrações de verapamil (Tabela 6). Os dados obtidos indicam que na concentração de $30 \mu \mathrm{M}$ este composto diminui em cerca de $50 \%$ a $\mathrm{CI}_{50}$ para $\mathrm{BZ}$, aumentando, portanto, a suscetibilidade das cepas a esta droga.

Tabela 7 - Efeito de ciclosporina A na suscetibilidade a BZ $\left(\mathrm{CI}_{50}\right)$ em cepas de $T$. cruzi.

\begin{tabular}{lccc}
\hline \multirow{2}{*}{ Cepa } & $\mathbf{0} \boldsymbol{\mu} \mathbf{M}$ ciclosporina $\mathbf{A}$ & \multicolumn{2}{c}{$\mathbf{1} \boldsymbol{\mu}$ ciclosporina $\mathbf{A}^{\mathbf{a}}$} \\
\cline { 2 - 4 } & $\mathrm{CI}_{50} \mathrm{BZ}$ & $\mathrm{CI}_{50} \mathrm{BZ}$ & Inibição $^{\mathrm{b}}(\%)$ \\
VL10 & $(\mu \mathrm{M})$ & $(\mu \mathrm{M})$ & 2 \\
Colombiana & 22,9 & 25,7 & 0 \\
\hline
\end{tabular}

${ }^{\mathrm{a}}$ Concentração abaixo da $\mathrm{CI}_{50}$ da ciclosporina $\mathrm{A}$.

${ }^{b}$ Porcentagem de inibição da $\mathrm{CI}_{50}$ de $\mathrm{BZ}$ em relação à $\mathrm{CI}_{50}$ da cultura controle em ausência de ciclosporina A. Média de dois experimentos independentes.

O efeito de ciclosporina A no fenótipo de resistência a BZ foi investigado em duas cepas resistentes a BZ, utilizando-se uma concentração fixa do composto $(1 \mu \mathrm{M})$, abaixo de sua $\mathrm{CI}_{50}$ (ver Tabela 5). Na Tabela 7 apresentam-se os resultados obtidos (média de dois 
experimentos independentes), que indicam que este composto não tem efeito apreciável na suscetibilidade a BZ de T. cruzi.

O efeito de FTC no fenótipo de resistência a BZ foi investigado em CL Brener e VL10, utilizando-se concentrações fixas do composto $(1,5$ e $7 \mu \mathrm{M})$. Verificamos que o composto não alterou a suscetibilidade a BZ nas cepas analisadas (dados não mostrados).

\subsection{Caracterização do gene do transportador $T c A B C G 1$ de $T$. cruzi}

\subsubsection{Amplificação da sequência completa do gene TcABCG1}

Para a amplificação do gene do transportador $T c A B C G 1$ de cepas de $T$. cruzi, desenhamos oligonucleotídeos iniciadores com base na sequência nucleotídica do haplótipo não Esmeraldo de CL Brener (GenBank: Tc00.1047053508231.190). A ORF do gene tem 1998 pb e codifica 665 aminoácidos, o que corresponde a uma proteína de cerca 75 kDa. Na Figura 6 apresentamos a sequência nucleotídica deste gene, indicando a localização dos motivos Walker A, Walker B e assinatura $\mathrm{ABC}$ e a posição e sequência dos iniciadores utilizados para a amplificação. Os iniciadores contêm os sítios de restrição para XbaI (iniciador forward) e XhoI (iniciador reverse). A PCR foi realizada com a enzima Pfu DNA polimerase, que possui alta atividade de correção de erros durante o processo de síntese do DNA, e que gera fragmentos com pontas cegas. Os produtos da amplificação de TcABCG1 foram purificados com o kit PureLink ${ }^{T M}$ PCR Purification Kit (Invitrogen).

O gene TcABCG1 foi amplificado por PCR a partir do DNA genômico de cinco cepas (ver abaixo).

\footnotetext{
TCTAGAATGTCTTGCTGCCGAGCGGAGGTGAATGAGCCAGTAACTCCCAGCTCCGCCTCATCATTGGAGT CTGACGACCAAATCGCGCCGAAGCAGAAGGGTAACGAACCCCAAATCGAAGACTATAGCATCATCGCCCC CGGATTCTCCATCAAGGGCTCCGTCGCGCAGTTCGACGCTGTGGAACAAAATAAGAGCTCCGTGAGTGGA CGCTTTTCTATTCCCGTCTCATGGCATAATTTGTCATATTCGGCAAACGGCACGAAAATTCTTTGCGGCC TCACAGGAACAGCGTTACCATCACGATGCCTTGCTGTGATGGGATCCAGCGGTGCGGGCAAGACGACTTT TCTCAATGCTATCTCTGACCGACTTACAACCTCGCGTACCCTCAAGCTGACAGGGAAACGCCAGCTGGGG GACTTGGAGTACAAGCGTCATTACCGCAGGATGGTTGGTTTTGTGGCGCAAGACGACATTCTCTCCCCAC GGGCAACACCCGAAGATTCCCTTCGCTTTTCGCTGCGCGTGAGGCGTGGCACAAGCATAAGTGAAACGAA TAAATTTGTTGAGGAAACTTTGGAGGAATTACGCCTTGTCCACTGCCGCGAGACCATTGTTGGTATCCCT GGCCTTGTCTCTGGTCTTTCGGGTGGTGAACGCAAACGCACAAGTATTGGTGTGGAGCTCATTTGCGATC CTAAAATTCTGTTGCTGGATGAACCCACCTCTGGTCTGGACTCCGTGACATCTGTGAAGATTGTGCATCT TCTGAATAACATTGCCCGAACTGGCCGCACGGTGATTTACACCATTCACCAGCCCACTGCTGAGACATTG ACGTACTTTGATGATCTCATGCTTCTCACCGGGGGTCGATGTGCTTATCATGGCACGATGGCAAAATCCG TGGAATACTTTGAGTCCATCGGATTCCCTTGTCCTGAACGATATACGCCAAGCGATTTCTTTATGAAGTT GCTCCAAGATCCAGAAATTCCAAGGTACTGGTTAAAAAATGGAAGAGCTATCTAAAACATGGTGTGAGA ACCCCACATACAACCGCGGTTGAGCTAAATCCCAATCCCTCCGAGTCTCCCACCGCGAAAAATATTGAAA GCTACCTTGGTAGGTTTGGGAGCACCTCGTGTATCCAATTCCAGGAGCTTTTTCGTCGTTTTTCCATGGA
} 


\begin{abstract}
TCTCAGTCGGAATCATGTATACATTTTTTCACATTTTATACAGGCTGCCTTCTTTGCAGTGATTGTGGGT CTCATATTTCTGAATGTTAAAGATGATTTAGCTGGTATGCAGGATCGCGAGGGAGTTTTTTTCATGGTAA CGATGAATCGGGCTATGGGGCAGACTTTTATCATGGTCAACTCCTTTATGCAAGATAAGGCCTTGTACGT GCGGGAGCAAATGGTTGGCTCATACTCCCCTTTTATTTTCTTTTTATCAAAAACCCTGGTGGAGTTTCCA ATGCGCGTATTTTTTGCCTTTCTTGAGTGCTGTATTTTATACTGGATGGTGGGTCTTTACCGCCAGGCAG GAGCTTTTTTTTACTACTTTGCGGTCATCGCGCTGCTTACTGAAGTGGCCTCGGGTCTTGGGTTTGCCAT TGGTGCCACGTTTAAAAGTTTGGTCGTTGCTTCCGGTACCGCGCCTGTGATTTTGCTACCGCTTGCCATG GTCGGTGGTCTTTTGGCGAACACAGATCGACTGCATCCGTATTGGTACTGGTTGGAGAAGCCATCCTTTA TTCGTCAGGCCTATATTCTTCTTGCCCGCAATGAATTTAAGCATATCGACCACATTCGGTGTGATGGTAG AGGCAAACCACCGGGCTTCTGTAAAGATAAGCCCCAAAACGGCGAGGATATCTTGCGCCAACTTGGGTTT CAGCAGAAGCAATATGAAAACTGGGTTTTGTGGCTAACTCTTGCCCTTTTATATATTGCTTTCCGCGGTT GGGCCGTTATTTCCTTGTACTCTGCCGCGCGTACAAAGTTTTAGCTCGAG
\end{abstract}

Figura 6 - Sequência nucleotídica completa do gene TcABCG1 (haplótipo não Esmeraldo de CL Brener). A posição dos iniciadores para a PCR é indicada em amarelo e os sítios para as enzimas de restrição, em cinza. Motivos: Walker A em azul, assinatura $\mathrm{ABC}$ em verde e Walker B em vermelho.

\title{
4.3.2 Clonagem no vetor pGEM-T Easy
}

O vetor de clonagem pGEM-T Easy (Promega) tem um tamanho de $3015 \mathrm{pb} \mathrm{e}$ apresenta uma timina protuberante em cada uma de suas extremidades 5'. Para a clonagem do gene TcABCG1 neste vetor, adicionamos adenina nas extremidades 3' do produto de PCR, seguida de uma reação de ligação com razão molar de 3:1 (inserto:vetor). O DNA dos clones recombinantes, obtidos após transformação de bactérias competentes E.coli DH5- $\alpha$, foi sequenciado.

\subsubsection{Análisse das sequências do gene TcABCG1 de cepas de T. cruzi}

As sequências do gene TcABCG1 das cepas Berenice 62, Silvio, VL10 e YuYu foram obtidas e comparadas com as sequências dos haplótipos Esmo e Não Esmo de CL Brener por múltiplo alinhamento de sequências pela utilização do CLUSTALW e visualização/edição pelo BioEdit (Figura 7). No BioEdit foram obtidas as sequências de aminoácidos pela ferramenta de tradução de sequências nucleotídicas. As variações alélicas entre as sequências são destacadas (Figura 7). 
10

CLBrenerNEsmo CLBrenerEsmo Berenice 62 Sílvio VL-10 YuYu MSCCRAEVNEPVTPSSASSIESDDOIAPKOKGNEPOIEDYSIIAPGFSIKGSVAOFDAVEONKSSVSGRFSIPVSWHNLSYSANGTKILCGLTGTALPSR MSCCRAEVNEPVTPSSASSLESDDOIASKOKGNEPITEDYSIIAPGFSIKGSVAOFDAVEONKSSVSGRFSIPVSWHNIAYSANGTKILCGLTGTALPSR MSCCRAEVNEPVTPSSASSLESDDQIASKOKGNEPLIEDYSI IAPGFSIKGSVAQFDAVEQNKSSVSGRFS IPVSWHNLAYSANGTKILCGLTGTALPSR MSCCRAEVNEPVTPSSASSLESDDQIASKQKGNEPQIEDYSIIAPGFFIRGSVAQFDAVEQNKSSVSGRFS IPVSWHNLAYSANGTKILCGLTGTALPSR MSCCRAEVNEPVTPSSASSLESDDQIASKQKGNEPLIEDYSIIAPGF IKGSVAQFDAVEQNKSSVS GRFSIPVSWHNLAYSANGTKILCGLTGTALPSR MSCCRAEVNEPVTPSSASSLESDDQIASKQKGNEPQIEDYSIIAPGFFIRGSVAQFDAVEQNKSSVSGRFSIPVSWHNLAYSANGTKILCGLTGTALPSR

110

120

130

140

150

160

170

180

190

200

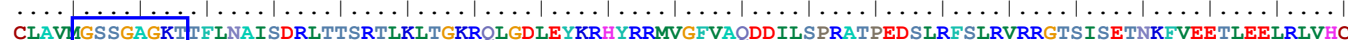
CLAV 1 GSSGAGKTIFLNAISDRLTTSRTLKLTGKRQLGDLEYKRHYRRMVGFVAQDDILSPRATPEDSLRFSLRVRRGTSISETNKFVEETLEELRLVHC CLAVIIGSSGA GKT TFLNAISDRLTTSRTLKLTGKRQLGDLEYKRHYRRMVGFVAQDDILSPRATPEDSLRFSLRVRRGTSISETNKFVEETLEELRLVHC CLAVAGSSGAGKITFLNAISDRLKT SRTLKLTGKRQLGDLEYKRHYRRMVGFVAQDDILSPRATPEDSLRFSLRVRRGTS ISETNKFVEETLEELRLVHC CLAVIGSSGAGKITFLNAISDRLTTSRTLKLTGKRQLGDLEYKRHYRRMVGFVAQDDILSPRATPEDSLRFSLRVRRGTSISETNKFVEETLEELRLVHC

CLBrenerEsmo Berenice62 Sílvio

VL-10

YuYu

210

220

230

240

250

260

270

280

290

300

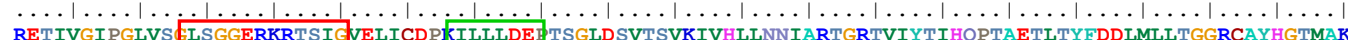
RETIVGIPGLVS \&LSGGERKRTSIGVELICD PKILLLDE PTSGLDSVTSVKIVHLLNNIARTGRTVIYTIHQPTAETLTYFDDLMLLTGGRCAYHGTMA RETIVGIPGLVS \&LSGGERKRTSIGVELICDPKILLLDE耳TSGLDSVTSVKIVHLLNNIARTGRTVIYTIHQPTAETLTYFDDLMLLTGGRCAYHGTMAK RETIVGIPGLVS \&LSGGERKRTSI VVELICDPKILLLDE PTSGLDSVTSVKIVHLLNNIARTGRTVIYTIHQPTAETLTYFDDLMLLTGGRCAYHGTMAK RETIVGIPGLVS ELSGGERKRTSI VVEICDPKILLIDE P TSGLDSVTSVKIVHLLNNIARTGRTVIYTIHQPTAETLTYFDDLMLLTGGRCAYHGTMAK RETIVGIPGLVS LSGGERKRTSI VVELICD PKILLIDE RETIVGIPGLVS LLSGGERKRTSIGVELICDPKILLLDEHTSGLDSVTSVKIVHLLNNIARTGRTVIYTIHQPTAETLTYFDDLMLLTGGRCAYHGTMAK

310

320

330

340

350

360

370

380

390

400

$\ldots \ldots|\ldots| \ldots|\ldots| \ldots|\ldots| \ldots|\ldots| \ldots|\ldots| \ldots|\ldots| \ldots|\ldots| \ldots|\ldots| \ldots|\ldots| \ldots|\ldots| \ldots|\ldots| \ldots|\ldots|$ SVEYFESIGF PCPERYTPSDFFMKLLQDPEISKVLVKKWKSYLKHGVRTPHTTAVELNPNPSESPTAKNIESYLGRFGSTSCIQFQELFRRF SMDLSRN SVEYFESIGFPCPERYTPSDFFMKLI DD SVEYFESIGFPCPERYTPSDFFMKLLQDPEISKVLVKKWKSYLKHGVRTPHTTAVELNPNPSESPTAKNIESYLSRFGSTSGIQFQELFRRFSIDLSRN SVEYFESIGFPCPERYTPSDFFMKLLQDPEISKVLVKKWKSYLKHGVRTPHTTAVELNPNPSESPTAKNIESYLSMFGSTSCIQFQELFRRFSIDLSRN SVEYFESIGF PCPERYTPSDFFMKLLQDPEISKVLVKKWKSYLKHGVRTPHTTAVELNPNPSESPTAKNIESYLSRFGSTSGIQFQELFRRFSIDLSRNH SVEYFESIGFPCPERYTPSDFFMKLLQDPEISKVLVKKWKSYLKHGVRTPHTTAVELNPNPSESPTAKNIESYLSMFGSTSCIQFQELFRRFSIDLSRNH Berenice62 Sílvio VL-10 YuYu

$$
410
$$

420

430

440

450

460

470

480

490

500

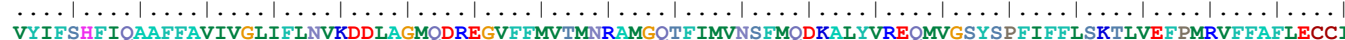
VYIFSHFIOAAFFAVIVGLIFLNVKDDLAGMODREGVFFMVTMNRAMGOTFIMVNSFMODKPLYYREOMVGSYSPFIFFLSKTLVEFPMRVFFAFLECC VYIFSHFIOAAFFAVIVGLIFLNVKDLA GMODREGVFFMVTMNRAMGOTFIMVNSFMODKPLYVREOMVGSYSPFIFFLSKTLVEFPMRVFFAFLECCI

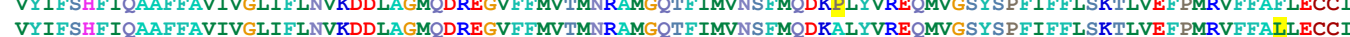
VYIFSHFIQAAFFAVIVGLIFLNVDDLAGMQDREGVFFMVTMNRAMGQTF IMVNSFMQDKALYVREQMVGSYSPFIFFLSKTLVEFPMRVFFALLECCI
VYIFSHFIQAAFFAVIVGLIFLNVKDDLAGMODREGVFFMVTMNRAMGQTFIMVNSFMODKPLYVREOMVGSYSPFIFFLSKTLVEFPMRVFFAFLECCI VYIFSHFIQAAFFAVIVGLIFLNVKDDLA GMODREGVFFMVMNRAMGQTF IMVNSFMQDKALYVREQMVGSYSPFIFFLSKTLVEFPMRVFFALLECCI Sílvio

VL-10

YuYu

\section{0}

550

560

570

580

590

600

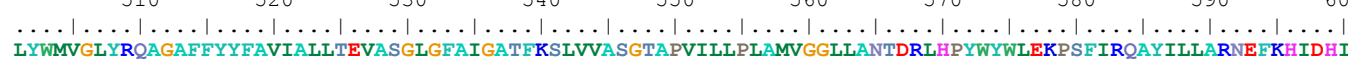
LYWMVGFYROAGAFFYYFAVIALLTEVASGLGFAIGATFKSLVVASGTAPVILLPLAMVGGLLANTDRLHPYWYWLEKPSF IROAYILLARNEFKHIDH LYWMVGFYRQAGAFFYYFAVIALLTEVASGLGFAIGATFKSLVVASGTAPVILLPLAMVGGLLANTDRLHPYWYWLEKPSFIROAYILLARNEFKHIDHI LYWMVGLYROA LYWMVGFYROA LYWMVGFYRQAGAFFYFAVIALLTEVASGLGFAIGATFKSLVASGTAPVILLPLAMVGGLLANTDRLHPYWYWLEKPSF IRQAYILLARNEFKHIDHI
LYWMVGLYRQAGAFFYFAVIALLTEVASGLGFAIGATFKSLVVASGTAPVILLPLAMVGGLIANTDRLHPYWYWLEKPSFIRQAYILLARNEFKHINHI CLBrenerEsmo Sílvio VL-10

$$
610 \quad 620 \quad 630 \quad 640 \quad 650 \quad 660
$$

$\ldots|\ldots| \ldots|\ldots| \ldots|\ldots| \ldots|\ldots| \ldots|\ldots| \ldots|\ldots| \ldots|\ldots| \ldots \mid$

CLBrenerNEsmo RCD GRGKPPGFCKDKPQNGEDILRQLGFQRQYENWVLWLTLALLYIAFRGWAVISLYSAARTKF*

CLBrenerEsmo RCDGRGKPPGYCKDKPQNGEDILRQLGFQQKQYESWILWLTLALLYIAFRGWAVISLYSAARTKF * Berenice62 Sílvio

$\mathrm{VL}-10$ RCD GRGKPPGYCKDKPONGEDILROLGFOOKOYESWILWLTLALLYIAFRGWAVISLYSAARTKF* RCDDRGKPPGFCKDKPQNGEDILRQLGFQOKOYESWVLWLTLALLYIAFRGWAVISLYSAARTKF* RCDGR KPPCYCKDKPONG RCDDRGKPPGFCKDKPONGEDILROLGFOOKOYESWVLWLTLALLYIAFRGWAVISLYSAARTKF *

Figura 7 - Alinhamento das sequências de aminoácidos do gene TcABCG1 de CL Brener haplótipos Esmeraldo e Não Esmeraldo (CL EL e CL NEL, respectivamente), Berenice 62, Silvio, VL10 e YuYu. Os aminoácidos variantes em relação à sequência CL NEL estão realçados em amarelo. As regiões com os motivos conservados estão delimitadas por caixas coloridas: Walker A em azul, assinatura $\mathrm{ABC}$ em vermelho e Walker B em verde.

Encontramos 41 variações alélicas entre as sequências nucleotídicas de Esmo e Não Esmo de CL Brener (Figura A.1 no Anexo A). A sequência de aminoácidos do transportador TcABCG1 de cada cepa foi comparada com a sequência proteica Não Esmo de CL Brener, uma vez que este haplótipo apresentou expressão aumentada na cepa resistente, quando comparada com a cepa sensível nas análises dos dados de microarranjos de DNA (ver Introdução; Moreno Vigo, 2008). Desta forma, verificamos que as sequências proteicas do transportador ABC de Berenice 62 e VL10 são idênticas àquela do haplótipo Esmo de CL 
Brener, enquanto que as sequências de aminoácidos de TcABCG1 de Silvio e YuYu são idênticas entre si, porém, diferenciam-se em 10 mutações não-sinônimas de aminoácidos em relação à sequência Não Esmo de CL Brener. Interessantemente, todas estas mutações encontram-se em regiões consideradas não-conservadas, não sendo encontradas nos motivos Walker A, assinatura ABC e Walker B (Figura 7).

Estas análises determinaram a escolha dos genes $T c A B C G 1$ a serem transfectados em CL Brener (ver item seguinte).

\subsection{Transfecção de genes $T c A B C G 1$ de cepas de $T$. cruzi em CL Brener}

\subsubsection{Os genes TcABCG1}

Decidimos transfectar em CL Brener os genes TcABCG1 das cepas VL10, Silvio e YuYu, consideradas resistentes a BZ (Tabela 4). A cepa VL10 pertence à DTU TcII e o gene codifica uma proteína de sequência idêntica à do haplótipo Esmo de CL Brener. As cepas Silvio e YuYu pertencem à DTU TcI, seus genes $T c A B C G 1$ têm sequências idênticas, e apresentam 10 mutações não-sinônimas de aminoácidos em relação à sequência Não Esmo de CL Brener. Como controle, foi transfectado também o haplótipo Não Esmo de CL Brener.

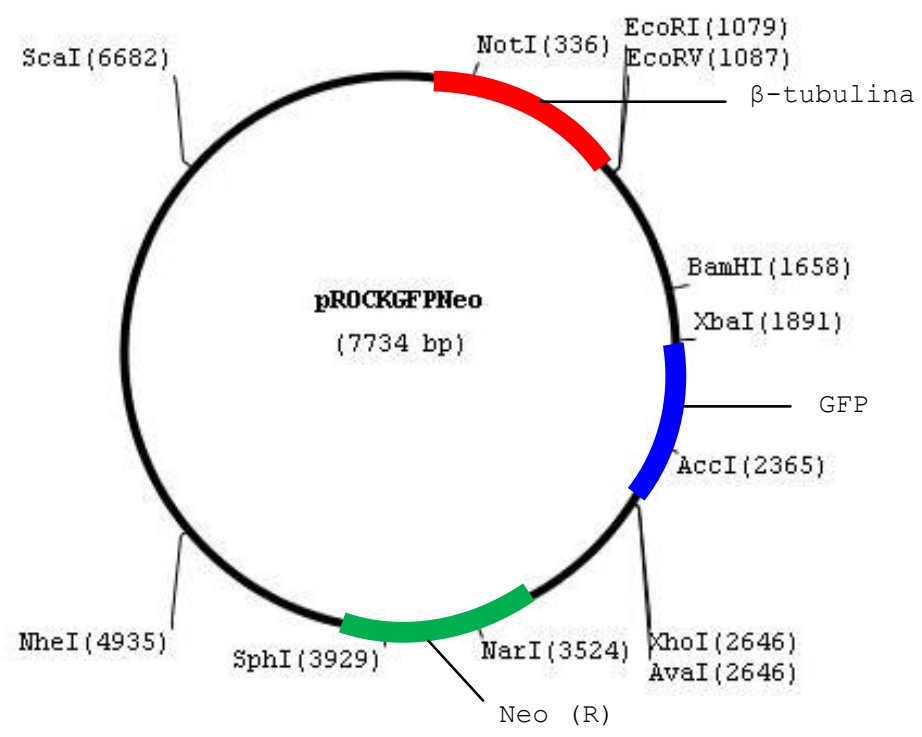

Figura 8 - Mapa do vetor pROCKGFPNeo (DaRocha et al., 2004). O gene TcABCG1 foi inserido no lugar do gene da GFP (em azul). O vetor permite a integração do gene a ser expresso no lócus da beta-tubulina (em vermelho). 
Os genes TcABCG1 clonados em pGEM-T Easy foram liberados do vetor por dupla digestão com XbaI e XhoI. Após purificação a partir de gel de agarose, os genes foram clonados no vetor pROCKNeo linearizado com as duas enzimas (DaRocha et al., 2004) (Figura 8). Este vetor permite a integração do gene de interesse no lócus de tubulina, por recombinação homóloga.

pROCKNeo contém a região promotora do gene ribossômico e também sequências derivadas das regiões flanqueadoras do gene GAPDH de T. cruzi, permitindo a expressão constitutiva e a maturação do mRNA do gene clonado em todos os estágios do parasita (DaRocha et al., 2004). Os plasmídeos recombinantes e plasmídeo vazio foram transfectados em CL Brener, conforme descrito em Material e Métodos. Os transfectantes foram selecionados em meio com G418 (neomicina). Nestas culturas, foi avaliada a suscetibilidade a BZ e NFX.

\subsubsection{Transfecções em T. cruzi}

Os vetores pROCKNeo recombinantes com o gene TcABCGl das quatro cepas e pROCKNeo não recombinante foram linearizados com NotI, purificados e eletroporados na cepa CL Brener. Em cada transfecção, utilizou-se massa de $50 \mu \mathrm{g}$ de DNA de cada plasmídio, conforme descrito no item 3.12 de Materiais e Métodos.

No esquema abaixo, resumem-se os pontos experimentais da eletroporação:

- Controle 1: $\mathrm{H}_{2} \mathrm{O}$;

- Controle 2: pTREXGFP contendo o gene da GFP;

- Controle 3: pROCKNeo não recombinante;

- pROCKNeoTcABCG1 de CL Brener;

- pROCKNeoTcABCG1 de VL10;

- pROCKNeoTcABCG1 de Silvio;

- pROCKNeoTcABCG1 de YuYu.

Após eletroporação, as culturas foram mantidas em meio de seleção contendo 200 $\mu \mathrm{g} / \mathrm{ml}$ de G418. A cultura transfectada com pTREXGFP, que contém o gene da GFP, foi utilizada para monitorar a eficiência da eletroporação. Após 24 horas, nesta cultura observamos que $4 \%$ dos parasitas apresentavam emissão de luz fluorescente verde. Este resultado indica alta eficiência de transfecção (DaRocha et al., 2004). A seleção dos parasitas 
transfectados se completou em 8 semanas, quando ocorreu a morte de todos os parasitas do Controle 1.

\subsubsection{Suscetibilidade a BZ e NFX}

Nos transfectantes contendo o gene TcABCG1 e na cepa CL Brener selvagem (wild type, WT) foi avaliada a suscetibilidade a BZ e NFX (Tabela 8). Nas culturas de CL Brener transfectadas com pROCKNeo contendo o gene TcABCG1, observa-se um aumento da resistência a BZ que varia de 11 a 32\%. Os maiores índices de aumento são observados para os genes das cepas Silvio e YuYu, 26 e 32\%, respectivamente. A transfecção do haplótipo Não Esmo de CL Brener e do haplótipo Esmo de VL10 causa incremento da resistência à droga da ordem de $10 \%$ (Tabela 8).

Tabela 8 - Suscetibilidade a BZ de CL Brener selvagem (WT) e transfectado com o gene TcABCG1 de diferentes cepas.

\begin{tabular}{lcc}
\hline Cultura $^{\mathbf{a}}$ & $\begin{array}{c}\mathbf{C I}_{\mathbf{5 0}} \mathbf{B Z}(\boldsymbol{\mu M}) \\
(\mathbf{m e ́ d i a} \pm \mathbf{d p})^{\mathbf{b}}\end{array}$ & Aumento da $\mathbf{C I}_{\mathbf{5 0}} \mathbf{B Z}(\mathbf{\%})^{\mathbf{c}}$ \\
\hline $\mathrm{CLBr}$ WT & $12,7 \pm 0,5$ & - \\
$\mathrm{CLBr}+\mathrm{pROCK}$ & $13,0 \pm 0,4$ & $2 \%$ \\
$\mathrm{CLBr}+\mathrm{ABC}_{\mathrm{CLBr}}$ & $14,5 \pm 0,2$ & $14 \%$ \\
$\mathrm{CLBr}+\mathrm{ABC}_{\mathrm{Silvio}}$ & $16,1 \pm 0,4$ & $26 \%$ \\
$\mathrm{CLBr}+\mathrm{ABC}_{\mathrm{VL} 10}$ & $17,1 \pm 0,7$ & $11 \%$ \\
$\mathrm{CLBr}+\mathrm{ABC}_{\mathrm{YuYu}}$ & $16,8 \pm 0,4$ & $32 \%$
\end{tabular}

${ }^{\mathrm{a}}$ Os experimentos foram realizados com formas epimastigotas de CL Brener selvagem (CLBr WT) e dos transfectantes com pROCKNeo vazio ou pROCKNeo contendo o gene TcABCGl de diferentes cepas (ver texto).

${ }^{\mathrm{b}}$ Média e desvio padrão das duplicatas de dois experimentos independentes.

${ }^{c}$ Aumento da $\mathrm{CI}_{50}$ para $\mathrm{BZ}$ em relação à $\mathrm{CI}_{50}$ de $\mathrm{CL}$ Brener WT.

O maior aumento da resistência a BZ nos transfectantes contendo o gene de Silvio e $\mathrm{YuYu}$ sugere que as características estruturais do transportador TcABCG1 das duas cepas resistentes à droga e pertencentes à DTU TcI confiram maior eficiência no efluxo da droga. Por outro lado, a cepa de CL Brener transfectada com estes genes não atinge os valores de $\mathrm{CI}_{50}$ para BZ (Tabela 4) observados nas cepas Silvio $(26,1 \pm 2,5 \mu \mathrm{M})$ e $\mathrm{YuYu}(40,5 \pm 1,8$ $\mu \mathrm{M})$. 
Uma vez que alguns transportadores $A B C$ podem atuar na resistência a múltiplas drogas, decidimos avaliar a suscetibilidade dos transfectantes a NFX (Tabela 9). Verificamos o aumento da resistência a NFX nas culturas transfectadas com os genes de todas as cepas, variando de 27 a $74 \%$. Neste caso, o maior aumento foi observado com a cepa transfectada com o gene de VL10.

Tabela 9 - Suscetibilidade a NFX de CL Brener selvagem (WT) e transfectado com o gene TcABCG1 de diferentes cepas.

\begin{tabular}{lcc}
\hline Cultura $^{\mathbf{a}}$ & $\mathbf{C I}_{\mathbf{5 0}} \mathbf{N F X}(\mathbf{m e ́ d i a} \pm \mathbf{d p} \boldsymbol{\mu M})^{\mathbf{b}}$ & Aumento da $\mathbf{C I}_{\mathbf{5 0}} \mathbf{N F X}(\boldsymbol{\%})^{\mathbf{c}}$ \\
\hline $\mathrm{CLBr}$ WT & $6,9 \pm 1,1$ & - \\
$\mathrm{CLBr}+$ pROCK & $6,3 \pm 0,9$ & - \\
$\mathrm{CLBr}+\mathrm{ABC}_{\mathrm{CLBr}}$ & $9,3 \pm 0,6$ & $34 \%$ \\
$\mathrm{CLBr}+\mathrm{ABC}_{\mathrm{VL} 10}$ & $12,0 \pm 2,3$ & $74 \%$ \\
$\mathrm{CLBr}+\mathrm{ABC}_{\mathrm{Silvio}}$ & $8,8 \pm 2,0$ & $27 \%$ \\
$\mathrm{CLBr}^{+} \mathrm{ABC}_{\mathrm{YuYu}}$ & $9,5 \pm 1,5$ & $37 \%$ \\
\hline
\end{tabular}

${ }^{\mathrm{a}}$ Os experimentos foram realizados com formas epimastigotas de CL Brener selvagem (CLBr WT) e dos transfectantes com pROCKNeo vazio ou pROCKNeo contendo o gene TcABCGl de diferentes cepas (ver texto).

${ }^{\mathrm{b}}$ Média e desvio padrão das duplicatas de dois experimentos independentes.

${ }^{c}$ Aumento da $\mathrm{CI}_{50}$ para NFX em relação à $\mathrm{CI}_{50}$ de $\mathrm{CL}$ Brener WT.

\subsubsection{Localização do gene TcABCG1 no genoma dos parasitas transfectados}

Em estudo inicial, investigamos a localização do gene TcABCG1 nas culturas transfectadas com o gene de CL Brener e VL10 e com pROCKNeo vazio. O DNA dos transfectantes foi digerido independentemente com BamHI e SalI e submetido à eletroforese em gel de agarose (Figura 9, painel A). Em seguida, o DNA foi transferido para membranas de nylon e hibridizado com sonda de 616 pb derivada do gene TcABCG1 de CL Brener e com sonda de $435 \mathrm{pb}$ derivada do gene de resistência à neomicina, marcador de pROCKNeo (ver Figura 9). Esta sonda foi obtida conforme descrito em DaRocha et al. (2004).

No Painel B da Figura 9, observa-se que a sonda do gene TcABCG1 hibridiza com uma banda adicional na amostra transfectada com o gene de CL Brener e digerida com BamHI. Este dado confirma a presença de uma cópia extra do gene. Curiosamente, esta banda não aparece na amostra transfectada com o gene de VL10. Este painel também mostra que a sonda do gene de CL Brener hibridiza mais fracamente com o DNA genômico de Silvio 
(WT), quando comparado com a hibridização com CL Brener (WT), confirmando diferenças na sequência nucleotídica do gene nas duas cepas.

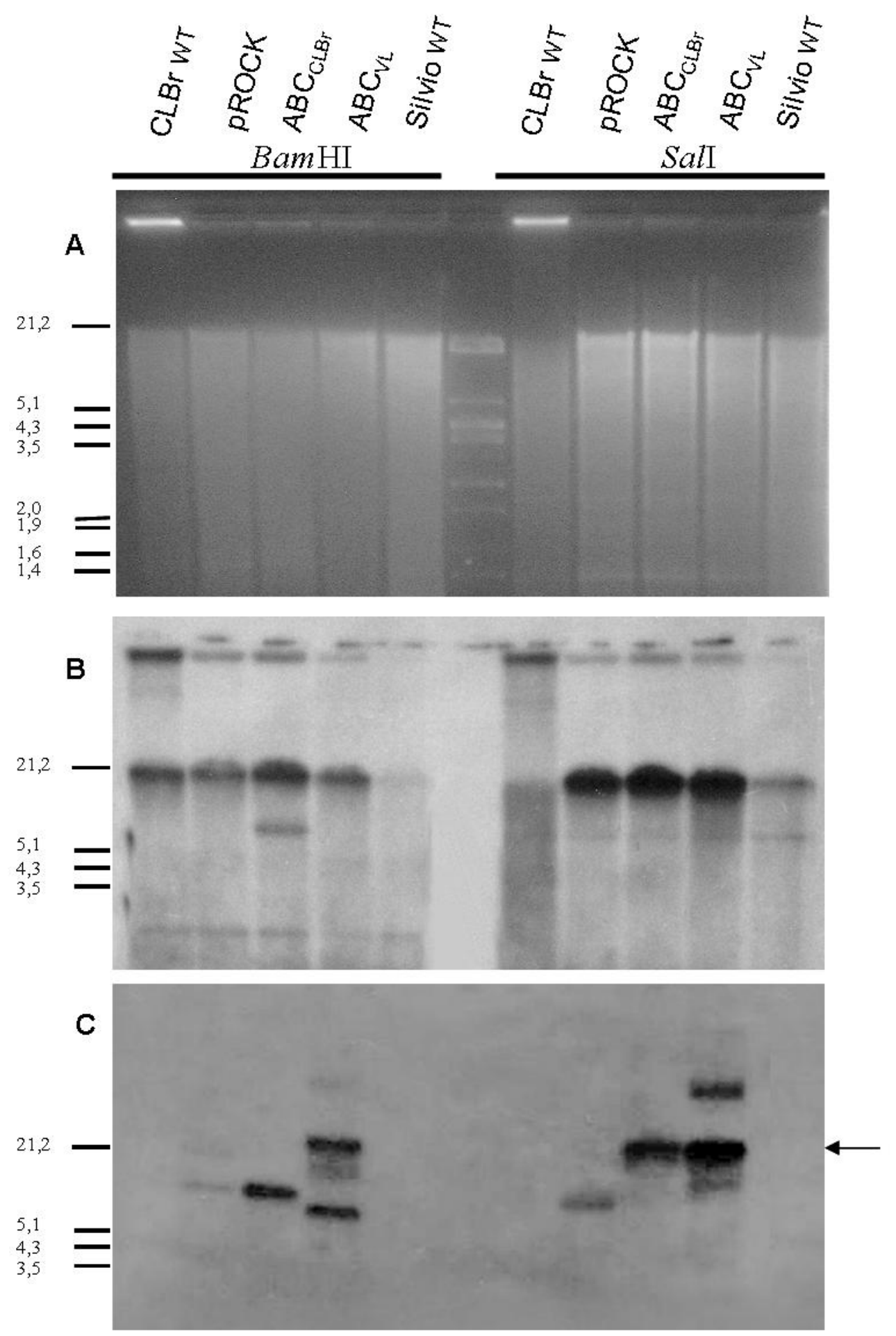

Figura 9 - Southern Blot: DNA genômico de CL Brener WT e transfectado com pROCKNeo vazio e pROCKNeo com o TCABCG1 de CL Brener e VL10, e da cepa Silvio WT, digerido com BamHI e SalI. Painel A: coloração do gel de agarose com brometo de etídio; painel B: hibridização com sonda do gene TcABCG1; painel C: hibridização com sonda do gene de resistência a neomicina. À esquerda dos painéis indica-se o tamanho molecular em kb. No painel C, seta indica a posição do gene $T c A B C G 1$. 
Para comprovar a integração do vetor pROCKNeo no genoma dos transfectantes, o DNA das amostras foi hibridizado com sonda derivada do gene de resistência à neomicina (Figura 9, painel C). Os dados indicam que o vetor está presente no genoma de todos os transfectantes. No entanto, o padrão das bandas de hibridização varia nas diferentes culturas, sugerindo que o vetor possa estar integrado em diferentes regiões do genoma de CL Brener. Esta situação foi observada anteriormente (Carlos Renato Machado, comunicação pessoal). Para verificar esta possibilidade, futuramente, as sondas dos genes $T c A B C G 1$ e de resistência a neomicina deverão ser hibridizadas com as bandas cromossômicas dos transfectantes separadas por eletroforese de campo pulsado (PFGE).
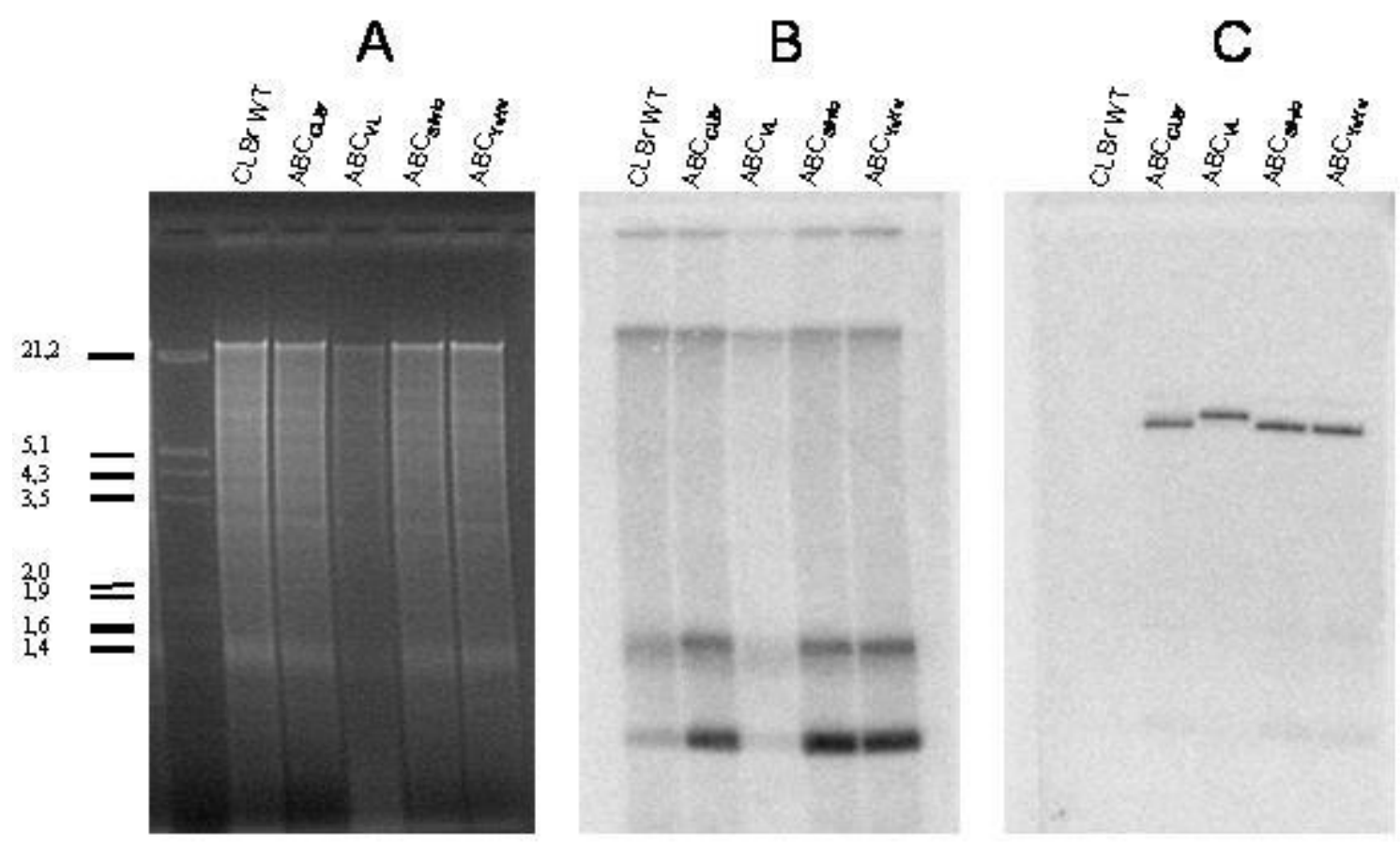

Figura 10 - Digestão de DNA genômico com SacII. Painel A: Padrão da migração em gel de agarose corado com brometo de etídio. Painel B: Hibridização com sonda de TcABCG1. Painel C: Hibridização com sonda do gene de resistência à neomicina. À esquerda dos painéis indica-se o tamanho molecular em $\mathrm{kb}$.

A localização do gene $T c A B C G 1$ nas culturas transfectadas com o gene de CL Brener, VL10, YuYu e Silvio foi investigada por Southern Blot após digestão do DNA com a enzima SacII (Figura 10). No painel A mostra-se o padrão da coloração do DNA com brometo de etídio, que indica que a amostra referente à transfecção com o gene de VL10 contém 76\% da massa de DNA que as outras amostras. As amostras foram hibridizadas com uma sonda para o gene TcABCGl constituída pela mistura dos produtos de amplificação (616 pb) do gene de CL Brener e de Silvio, isto porque a sonda de CL Brener hibridiza fracamente com o DNA de 
Silvio (ver Figura 9). No painel B da Figura 10 observa-se que o padrão de hibridização da sonda do gene $\mathrm{ABC}$ é o mesmo para todas as amostras. No entanto, o sinal de hibridização é mais fraco na amostra de CL Brener não transfectado (WT), além da amostra transfectada com o gene de VL10, pelo motivo exposto acima. Esta observação sugere que nas amostras transfectadas com os genes ABC de CL Brener, Silvio e YuYu o número de cópias do gene seja maior.

Após remoção da sonda do gene ABC, a membrana foi hibridizada com sonda do gene de resistência à neomicina (Figura 10, painel C). Uma banda de hibridização foi verificada nas quatro culturas transfectadas (com os genes de CL Brener, VL10, Silvio e YuYu). Entretanto, na amostra transfectada com o gene de VL10 a banda de hibridização apresenta um tamanho molecular diferente das demais, reforçando a hipótese de que o vetor pROCKNeo contendo o gene de VL10 tenha se integrado num lócus diferente.

Tabela 10 - Sinal de hibridização da sonda do gene ABC a partir de dados do Southern Blot ${ }^{\mathrm{a}}$.

\begin{tabular}{|c|c|c|c|c|c|c|}
\hline DNA $^{\mathbf{a}}$ & $\begin{array}{c}{\text { Banda } 1^{b}}_{(\text {Kpxls })}\end{array}$ & $\begin{array}{c}\text { Banda } 2^{b} \\
(\text { Kpxls) }\end{array}$ & $\begin{array}{c}\text { Banda } 3^{b} \\
\text { (Kpxls) }\end{array}$ & $\begin{array}{c}\text { Total }^{\mathrm{c}} \\
\text { (Kpxls) }\end{array}$ & $\begin{array}{c}\text { Total } \\
\text { corrigido } \\
\text { (Kpxls) }^{d}\end{array}$ & $\begin{array}{c}\text { Abundância } \\
\text { relativa de } \\
T c A B C G 1^{e} \\
\end{array}$ \\
\hline CLBr WT & 136,0 & 153,4 & 112,2 & 401,6 & 401,6 & 1,00 \\
\hline $\mathrm{CLBr}+\mathrm{ABC}_{\mathrm{CLBr}}$ & 146,3 & 258,1 & 220,3 & 624,7 & 624,7 & 1,55 \\
\hline $\mathrm{CLBr}+\mathrm{ABC}_{\mathrm{VL} 10}$ & 130,9 & 113,6 & 60,5 & 305,0 & 536,8 & 1,37 \\
\hline $\mathrm{CLBr}+\mathrm{ABC}_{\text {Silvio }}$ & 175,2 & 256,6 & 448,7 & 880,5 & 880,5 & 2,19 \\
\hline $\mathrm{CLBr}+\mathrm{ABC}_{\mathrm{YuYu}}$ & 178,7 & 283,0 & 469,6 & 931,3 & 913,3 & 2,27 \\
\hline
\end{tabular}

${ }^{\mathrm{a}}$ Dados extraídos do Southern da Figura 10, Painel B.

${ }^{\mathrm{b}}$ Banda 1, alto peso molecular; Banda 2, peso molecular intermediário; Banda 3, menor peso molecular. ${ }^{\mathrm{c}}$ Somatória do sinal de hibridização das três bandas.

${ }^{\mathrm{d}}$ Somatória do sinal de hibridização das três bandas, corrigido pela massa de DNA aplicada no gel. ${ }^{e}$ Abundância relativa do gene $\mathrm{ABC}$ foi calculada atribuindo ao valor de pixels totais de CL Brener WT, o valor unitário.

O sinal de hibridização da sonda do gene ABC (Painel B da Figura 10) foi determinado para cada uma das três bandas de hibridização das amostras. O cálculo foi realizado a partir do número de pixels capturado pelo programa ImageJ 1.44 (ImageJ, 2004), a partir da imagem gerada pela exposição ao Storm. Na Tabela 10 mostra-se o valor do sinal de cada banda, a somatória do sinal e a somatória do sinal corrigida pela massa de DNA aplicada na membrana. A partir deste valor, estimamos a abundância relativa do gene TcABCG1 nas amostras (Tabela 10). Os dados sugerem que nas amostras transfectadas com os genes de 
Silvio e YuYu haja o dobro de genes presentes em CL Brener WT. Nas culturas transfectadas com o gene de CL Brener e VL10 haveria, respectivamente, 1,55 e 1,37 vezes maior conteúdo gênico. Ressalta-se que esta estimativa é preliminar e estudos posteriores deverão ser conduzidos para sua comprovação.

\subsubsection{Abundância de transcritos de TcABCG1 nas culturas transfectadas}

A abundância relativa dos transcritos do gene TcABCG1 foi determinada por RT-PCR em tempo real, a partir de amostras de RNA total tratado com DNAse. Para comprovar a ausência de DNA contaminante nas amostras, realizamos uma PCR convencional com os iniciadores específicos para o gene ABC. Nenhum produto de amplificação foi obtido.

Nos ensaios de RT-PCR em tempo real utilizamos, para todas as amostras, uma massa de $200 \mathrm{ng}$ de cDNA (ver Material e Métodos). As amostras foram amplificadas com iniciadores específicos do gene ABC e de GAPDH de T. cruzi (este housekeeping gene foi utilizado como gene normalizador). Os experimentos foram realizados em placas de 96 poços, em triplicatas técnicas e duplicatas biológicas. Os dados foram analisados conforme descrito em Materiais e Métodos, e são apresentados na Tabela 11.

Tabela 11 - Razão da abundância relativa de transcritos de TcABCG1. Análise por RT-PCR em tempo real.

\begin{tabular}{cc}
\hline Cepa & $\begin{array}{c}\text { Abundância relativa de } \\
\text { transcritos de TcABCG1 }\end{array}$ \\
\hline $\mathrm{CLBr}$ WT & 1,00 \\
$\mathrm{CLBr}+$ pROCK & 0,80 \\
$\mathrm{CLBr}+\mathrm{ABC}_{\mathrm{CLBr}}$ & 2,70 \\
$\mathrm{CLBr}+\mathrm{ABC}_{\mathrm{VL} 10}$ & 1,12 \\
$\mathrm{CLBr}+\mathrm{ABC}_{\mathrm{Silvio}}$ & 2,85 \\
$\mathrm{CLBr}+\mathrm{ABC}_{\mathrm{YuYu}}$ & 2,67 \\
\hline
\end{tabular}

Observamos uma maior razão na abundância relativa de transcritos de TcABCG1 nas culturas de CL Brener transfectadas com o gene ABC de CL Brener $(2,70)$, Silvio $(2,85)$ e YuYu $(2,67)$. O valor da abundância de transcritos da cultura transfectada com o gene ABC de VL10 foi menor $(1,12)$, próximo ao valor obtido para as culturas de CL Brener WT $(1,00)$ e CL Brener transfectada com o vetor vazio $(0,80)$. Este resultado sugere que o gene de VL10 
tenha se integrado no genoma de CL Brener no lócus do gene $\mathrm{ABC}$ original, por recombinação homóloga. Esta hipótese deverá ser confirmada por hibridização das bandas cromossômicas, conforme explicitado acima.

\subsubsection{Quantificação da razão de abundância do gene TcABCG1 em cepas selvagens}

Levantamos a possibilidade de as diferenças na suscetibilidade das cepas a BZ (Tabela 4) serem ocasionadas pelo aumento do número de cópias do gene TcABCG1. Desta forma, estimamos a abundância deste gene no genoma das cepas em ensaios de PCR em tempo real (ver Material e Métodos). A curva padrão representando $10^{0}$ a $10^{7}$ cópias do gene foi construída utilizando-se o plasmídio pGEM-T Easy contendo o gene ABC de CL Brener. As duas curvas padrão foram lineares $\left(\mathrm{R}^{2}>0,999\right)$ (Figura 11).

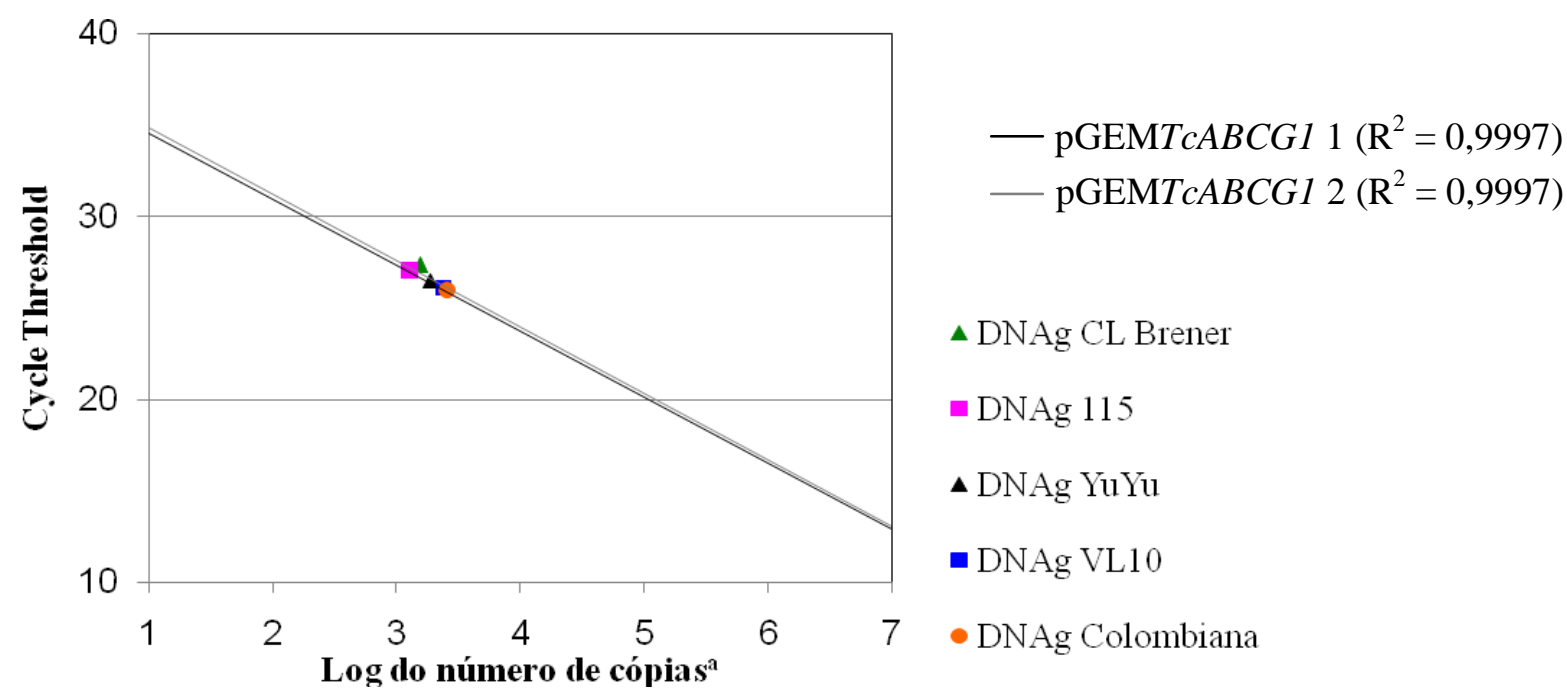

Figura 11 - PCR em Tempo Real para estimar o número de cópias do gene TcABCGl a partir de massa conhecida de DNA de cinco cepas. As duas retas do gráfico foram obtidas por duplicatas de diluições seriadas do plasmídeo pGEMTcABCGl (de $10^{0}$ a $10^{7}$ cópias).

${ }^{a}$ Os pontos coloridos do gráfico representam o Cycle Threshold em relação ao log do número de cópias obtido com 0,1 ng de DNA genômico de cada cepa.

Em paralelo, foi amplificado 0,1 ng de DNA de cada cepa. Para efeito de cálculo, a quantidade de genomas contida nesta massa foi calculada a partir do tamanho do genoma estimado para CL Brener (110 Mb) (El-Sayed et al., 2005) e a informação de que esta cepa possui duas cópias de TcABCG1 por genoma diplóide (TriTrypDB, 2011). Os experimentos foram realizados em triplicatas técnicas. Na Tabela 12 resumem-se os dados obtidos. 
Tabela 12 - Estimativa da abundância do gene TcABCG1 por PCR em tempo real.

\begin{tabular}{ccc}
\hline Cepa & $\begin{array}{c}\text { Abundância do gene } \\
\boldsymbol{T} \boldsymbol{c} \boldsymbol{A B C G \boldsymbol { 1 }}\end{array}$ & $\begin{array}{c}\text { Abundância relativa do } \\
\text { número de cópias do } \\
\boldsymbol{T} \boldsymbol{c} \boldsymbol{A} \boldsymbol{B} \boldsymbol{C G} \boldsymbol{C}\end{array}$ \\
\hline CL Brener & 1,87 & 1,00 \\
115 & 1,52 & 0,81 \\
VL10 & 2,84 & 1,52 \\
Colombiana & 3,05 & 1,63 \\
YuYu & 2,22 & 1,18 \\
\hline
\end{tabular}

O valor de abundância do gene $T c A B C G 1$ encontrado para a cepa referência CL Brener (1,87 cópias) foi bem próximo ao valor esperado de 2 de cópias do gene presentes no genoma desta cepa. A abundância relativa do número de cópias do gene TcABCG1 das cepas foi calculado em relação ao número de cópias do gene de CL Brener, atribuindo-lhe valor unitário (Tabela 12). Verificamos haver pequena variação numérica que não apóia a hipótese de que o aumento da resistência a BZ seja resultante do aumento do número de cópias do gene do transportador $\mathrm{ABC}$.

\subsection{Caracterização de proteínas ABC de $T$. cruzi}

\subsubsection{Identificação de proteínas ABC no genoma de CL Brener}

Numa primeira etapa, foram selecionados os genes de CL Brener anotados no banco de dados TriTrypDB como putative ABC transporter. Identificamos 42 genes. Em seguida, outros genes $\mathrm{ABC}$ hipotéticos foram identificados por buscas com o programa BLAST P utilizando-se, como entrada, algumas sequências da assinatura $\mathrm{ABC}$ de transportadores de $T$. cruzi previamente anotados. A sequência da assinatura ABC é específica dos transportadores $\mathrm{ABC}$ e os distingue das demais proteínas ligantes de ATP. Com este procedimento, o número de transportadores ABC hipotéticos subiu para 58 (Tabela 13 e Tabela A.1 no Anexo A). Este número representa $0,23 \%$ do número total de genes anotados em T. cruzi ( 25.000) (ElSayed et al., 2005). 
Tabela 13 - Características dos transportadores ABC de T. cruzi identificados no genoma de CL Brener.

(continua)

\begin{tabular}{|c|c|c|c|c|c|}
\hline Código de acesso do gene & Subfamília & Haplótipo $^{\mathrm{a}}$ & Cromossomo $^{b}$ & Topologia $^{c}$ & Pseudogene \\
\hline Tc00.1047053510149.80 & A & EL & 36 & $(\mathrm{TMD}-\mathrm{NBD})_{2}$ & \\
\hline Тc00.1047053506989.30 & A & NEL & 36 & $(\mathrm{TMD}-\mathrm{NBD})_{2}$ & \\
\hline Тc00.1047053504881.50 & A & EL & 7 & $(\mathrm{TMD}-\mathrm{NBD})_{2}$ & \\
\hline Тc00.1047053510045.20 & A & NEL & 7 & $(\mathrm{TMD}-\mathrm{NBD})_{2}$ & \\
\hline Тc00.1047053503573.9 & A & NEL & 27 & TMD-NBD & \\
\hline Тc00.1047053504149.20 & A & EL & 27 & $(\mathrm{TMD}-\mathrm{NBD})_{2}$ & \\
\hline Тc00.1047053507099.80 & A & EL & 14 & $(\mathrm{TMD}-\mathrm{NBD})_{2}$ & \\
\hline Тc00.1047053511725.80 & A & NEL & 35 & $(\mathrm{TMD}-\mathrm{NBD})_{2}$ & \\
\hline Тc00.1047053503749.60 & B & EL & 35 & NBD & \\
\hline Тc00.1047053511021.70 & B & NEL & 35 & TMD-NBD & \\
\hline Тc00.1047053511537.8 & B & EL & 35 & TMD-NBD & \\
\hline Тc00.1047053507093.260 & B & EL & 39 & TMD-NBD & \\
\hline Тc00.1047053510885.70 & B & NEL & 6 & NBD & \\
\hline Тc00.1047053506529.160 & B & EL & 6 & NBD & \\
\hline Тc00.1047053510785.10 & B & NEL & - & NBD & \\
\hline Тc00.1047053506619.90 & B & NEL & 23 & NBD & \\
\hline Тc00.1047053508809.30 & B & EL & 23 & NBD & \\
\hline Тc00.1047053506817.20 & B & NEL & 35 & TMD-NBD & \\
\hline Тc00.1047053507105.70 & B & EL & 35 & $(\mathrm{TMD}-\mathrm{NBD})_{2}$ & \\
\hline Тc00.1047053509007.99 & B & EL & 31 & NBD & $\operatorname{sim}$ \\
\hline Tc00.1047053511385.120 & B & NEL & 31 & NBD & \\
\hline Тc00.1047053510231.29 & $\mathrm{C}$ & EL & 34 & $(\mathrm{TMD}-\mathrm{NBD})_{2}$ & \\
\hline Тc00.1047053506559.100 & $\mathrm{C}$ & NEL & 34 & $(\mathrm{TMD}-\mathrm{NBD})_{2}$ & \\
\hline Тc00.1047053447255.29 & $\mathrm{C}$ & EL & 34 & NBD & \\
\hline Тc00.1047053508965.14 & $\mathrm{C}$ & NEL & 31 & TMD-NBD & \\
\hline Тc00.1047053507079.30 & $\mathrm{C}$ & EL & 31 & NBD & \\
\hline Тc00.1047053457101.30 & $\mathrm{C}$ & - & - & NBD & \\
\hline Тc00.1047053506417.83 & $\mathrm{C}$ & EL & - & NBD & $\operatorname{sim}$ \\
\hline Tc00.1047053506417.10 & $\mathrm{C}$ & EL & - & NBD & $\operatorname{sim}$ \\
\hline Tc00.1047053510431.150 & $\mathrm{D}$ & EL & 39 & TMD-NBD & \\
\hline Тc00.1047053506925.530 & $\mathrm{D}$ & EL & 39 & TMD-NBD & \\
\hline Тc00.1047053508927.20 & $\mathrm{D}$ & EL & 31 & TMD-NBD & \\
\hline Тc00.1047053509237.30 & $\mathrm{D}$ & NEL & 31 & TMD-NBD & \\
\hline Тc00.1047053464879.9 & $\mathrm{E}$ & NEL & 10 & NBD-NBD & \\
\hline Тc00.1047053508637.150 & E & NEL & 10 & NBD-NBD & \\
\hline Тc00.1047053511913.9 & E & NEL & 10 & NBD & $\operatorname{sim}$ \\
\hline Тc00.1047053504867.20 & $\mathrm{F}$ & EL & 36 & NBD-NBD & \\
\hline Тc00.1047053510943.80 & $\mathrm{F}$ & NEL & 36 & NBD-NBD & \\
\hline Тc00.1047053508897.30 & $\mathrm{F}$ & NEL & 40 & NBD-NBD & \\
\hline Tc00.1047053509105.130 & $\mathrm{F}$ & NEL & 37 & NBD-NBD & \\
\hline Тc00.1047053506249.70 & G & NEL & 37 & NBD-TMD & \\
\hline Тc00.1047053508231.190 & G & EL & 37 & NBD-TMD & \\
\hline
\end{tabular}


Tabela 13 - Características dos transportadores ABC de T. cruzi identificados no genoma de CL Brener

(conclusão)

\begin{tabular}{|c|c|c|c|c|c|}
\hline Código de acesso do gene & Subfamília & Haplótipo $^{\mathrm{a}}$ & Cromossomo $^{b}$ & Topologia $^{c}$ & Pseudogene \\
\hline Tc00.1047053506579.10 & $\mathrm{G}$ & EL & 7 & NBD-TMD & \\
\hline Tc00.1047053507241.39 & G & NEL & 7 & NBD & \\
\hline Тс00.1047053506457.149 & $\mathrm{G}$ & EL & 10 & NBD & \\
\hline Тc00.1047053509693.190 & $\mathrm{G}$ & NEL & 10 & NBD-TMD & \\
\hline Тc00.1047053507951.280 & $\mathrm{G}$ & NEL & 36 & NBD-TMD & \\
\hline Тc00.1047053507681.100 & G & NEL & 4 & NBD-TMD & \\
\hline Tc00.1047053503593.60 & G & EL & 39 & NBD-TMD & \\
\hline Тc00.1047053506127.120 & $\mathrm{G}$ & EL & 39 & NBD-TMD & \\
\hline Tc00.1047053504425.70 & $\mathrm{G}$ & EL & 22 & NBD-TMD & \\
\hline Тc00.1047053509331.200 & $\mathrm{G}$ & NEL & 22 & NBD-TMD & \\
\hline Tc00.1047053509617.80 & $\mathrm{H}$ & NEL & 36 & NBD & \\
\hline Tc00.1047053509669.30 & $\mathrm{H}$ & EL & 36 & NBD & \\
\hline Tc00.1047053510381.20 & $\mathrm{H}$ & EL & 27 & NBD & \\
\hline Tc00.1047053506905.40 & $\mathrm{H}$ & NEL & 27 & NBD & \\
\hline Tc00.1047053511501.30 & $\mathrm{H}$ & NEL & 37 & NBD-NBD & \\
\hline Tc00.1047053511753.100 & $\mathrm{H}$ & EL & 32 & NBD & \\
\hline
\end{tabular}

${ }^{a}$ Haplótipos do tipo Esmeraldo (EL) ou Não-Esmeraldo (NEL).

${ }^{\mathrm{b}}$ Localização cromossomal.

'Ordem dos domínios NBD e TMD.

\subsubsection{Genes alelos e ortólogos}

A partir de informações do TriTrypDB, verificamos que dentre os 58 transportadores ABCs de T. cruzi, 36 possuem um alelo identificado, confirmando a presença de 18 pares de alelos de transportadores ABC (Tabela 13). Por outro lado, 22 haplótipos não foram encontrados, sugerindo erros na montagem do genoma de CL Brener ou até mesmo perda gênica.

O programa OrthoMCL foi utilizado para a busca de genes ABC ortólogos aos de $T$. cruzi nas espécies L. braziliense, L. infantum, L. major, L. mexicana, T. brucei, T. gambiense, T. congolense e T. vivax. Dos 58 genes de $T$. cruzi, encontramos 74\% (43/58) de genes ortólogos no genoma de L. infantum, L. major, L. braziliensis e L. mexicana; e 60\% (35/58) de genes ortólogos no genoma de T. brucei, $T$. congolense, $T$. brucei gambiense e T. vivax. 


\subsubsection{Localização cromossômica dos transportadores ABC de T. cruzi}

A localização cromossômica de 54 proteínas $\mathrm{ABC}$ putativas foi identificada a partir de informações do TriTrypDB (Tabela 13). Na Figura 12 compilamos sua distribuição nos 41 cromossomos de CL Brener, previamente descritos (Wethearly et al., 2009). Observa-se que os genes $\mathrm{ABC}$ distribuem-se em 16 cromossomos, sendo que o gene TcABCG1 localiza-se no cromossomo 37. Os cromossomos 7, 10, 27, 31, 35, 36, 37 e 39 apresentam uma maior abundância de genes $\mathrm{ABC}$ (quatro ou mais genes).
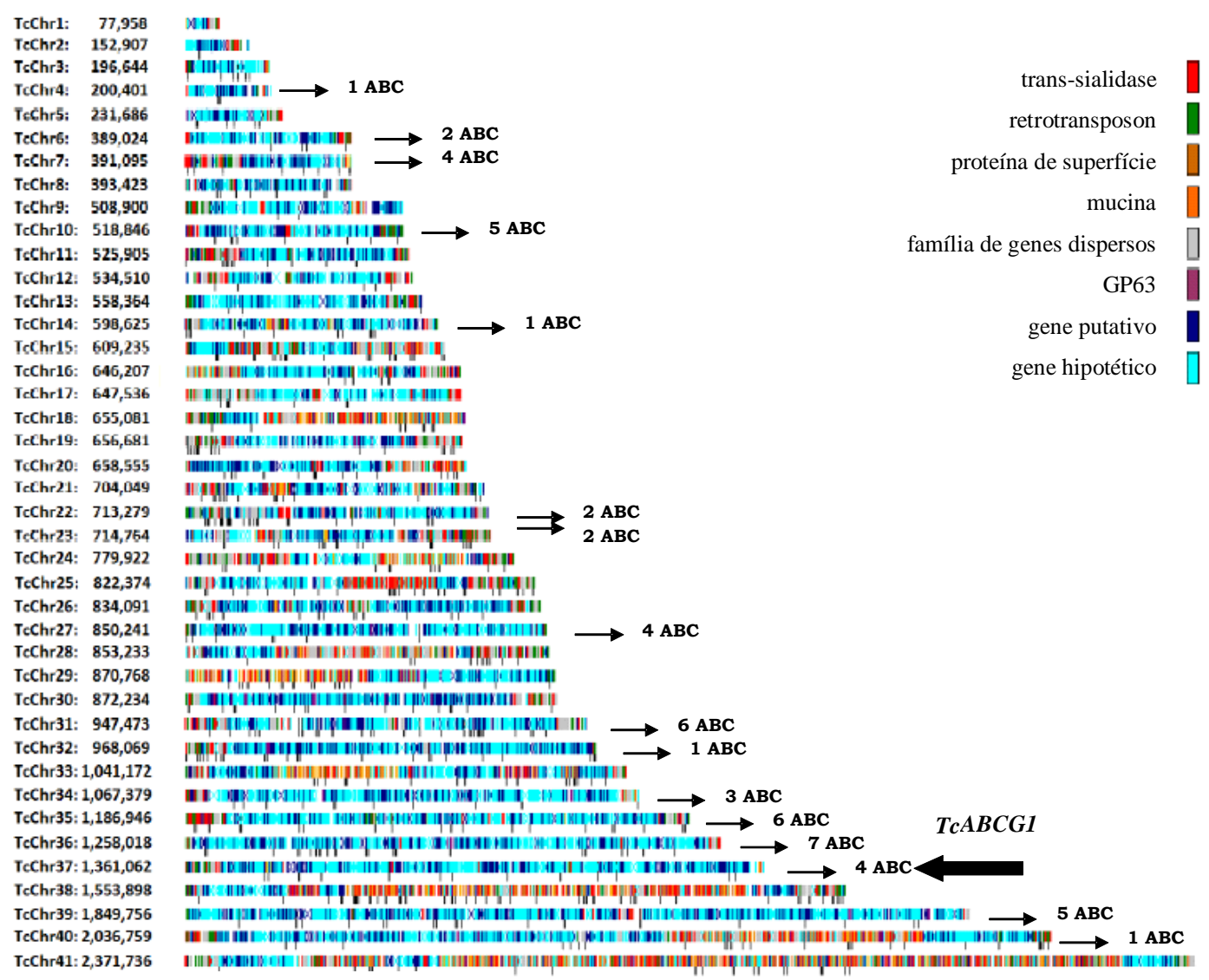

Figura 12 - Representação esquemática dos 41 cromossomos de CL Brener e localização de famílias gênicas. A localização e número das proteínas $\mathrm{ABC}$ hipotéticas são indicadas. Destaca-se a localização do gene $T c A B C G 1$.

Fonte: compilada por Weatherly et al., 2009.

\subsubsection{Análise da estrutura das proteínas ABC hipotéticas}

A estrutura de cada proteína $\mathrm{ABC}$ hipotética, no que se refere à presença, disposição e número dos domínios NBDs e TMDs foi analisada a partir de dados do TriTrypDB e banco de 
estrutura de proteínas PDB (Berman et al., 2000). Os dados são compilados na Tabela 13. Conforme descrito na Introdução (ver Figura 3, extraída de Sauvage et al., 2009), as proteínas ABC que apresentam dois TMDs e dois NBDs (TMD-NBD) 2 são consideradas transportadores completos (full-size transporters), ao passo que meio-transportadores (halfsize transporters) são constituídos por um único NBD fusionado com um único TMD. A localização N- ou C-terminal desses domínios determina a organização estrutural da proteína, sendo representada por TMD-NBD ou NBD-TMD.

Verificamos ainda que das 58 ORFs identificadas, 36 (62\%) apresentam motivos transmembrana, podendo estar localizadas na membrana plasmática ou na membrana de organelas. Não apresentam domínio transmembranar 22 ORFs (38\%), podendo estar localizadas no citoplasma (Figura 13).

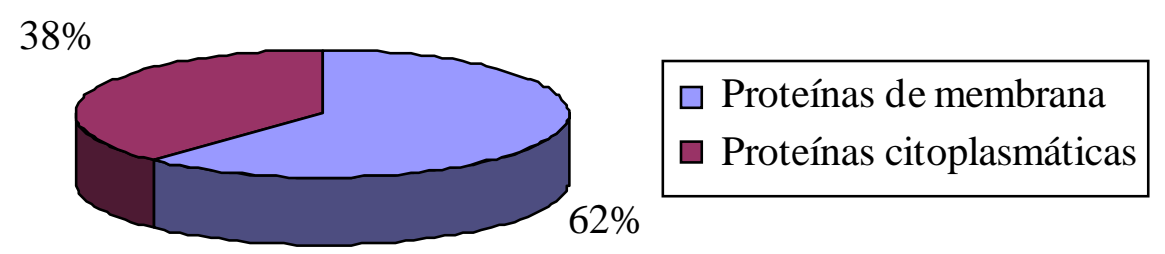

Figura 13 - Localização celular putativa das proteínas ABC de T. cruzi.

\subsubsection{Análises filogenéticas e classificação dos transportadores ABC de T. cruzi}

A metodologia utilizada para as análises filogenéticas dos transportadores $\mathrm{ABC}$ de $T$. cruzi seguiu as abordagens de Leprohon et al. (2006), Sheps et al. (2004) e Sauvage et al. (2009).

Com base na informação relativa às 58 sequências proteicas dos transportadores $A B C$ hipotéticos de CL Brener, extraímos as sequências correspondentes aos motivos Walker A, Walker B e assinatura ABC dos NBDs. Os dois NBDs de transportadores completos (full-size transporters) foram tratados independentemente nos alinhamentos, e estão identificados pelas letras minúsculas " $a$ " e " $b$ " logo após o conjunto de letras que identifica as sequências, na Figura 14. Sequências de um representante de cada uma das subfamílias A-G (de humanos) e H (de L. major, visto que não há esta subfamília em humanos) foram incorporadas à análise para a definição de cada subfamília.

A partir do múltiplo alinhamento foi gerada árvore filogenética pelo método de neighbor-joining (Figura 14). A árvore resultante permite a visualização de agrupamentos 
distintos das subfamílias. Os transportadores $\mathrm{ABC}$ das subfamílias A, D, E, F, G e $\mathrm{H}$ formam grupos monofiléticos, ao passo que transportadores $\mathrm{ABCB}$ e $\mathrm{ABCC}$ formam grupos parafiléticos. Desta forma, o critério para classificação dos transportadores dentro das subfamílias B e C, baseado apenas em filogenia, não é suficiente para a classificação destes transportadores em subfamílias distintas.

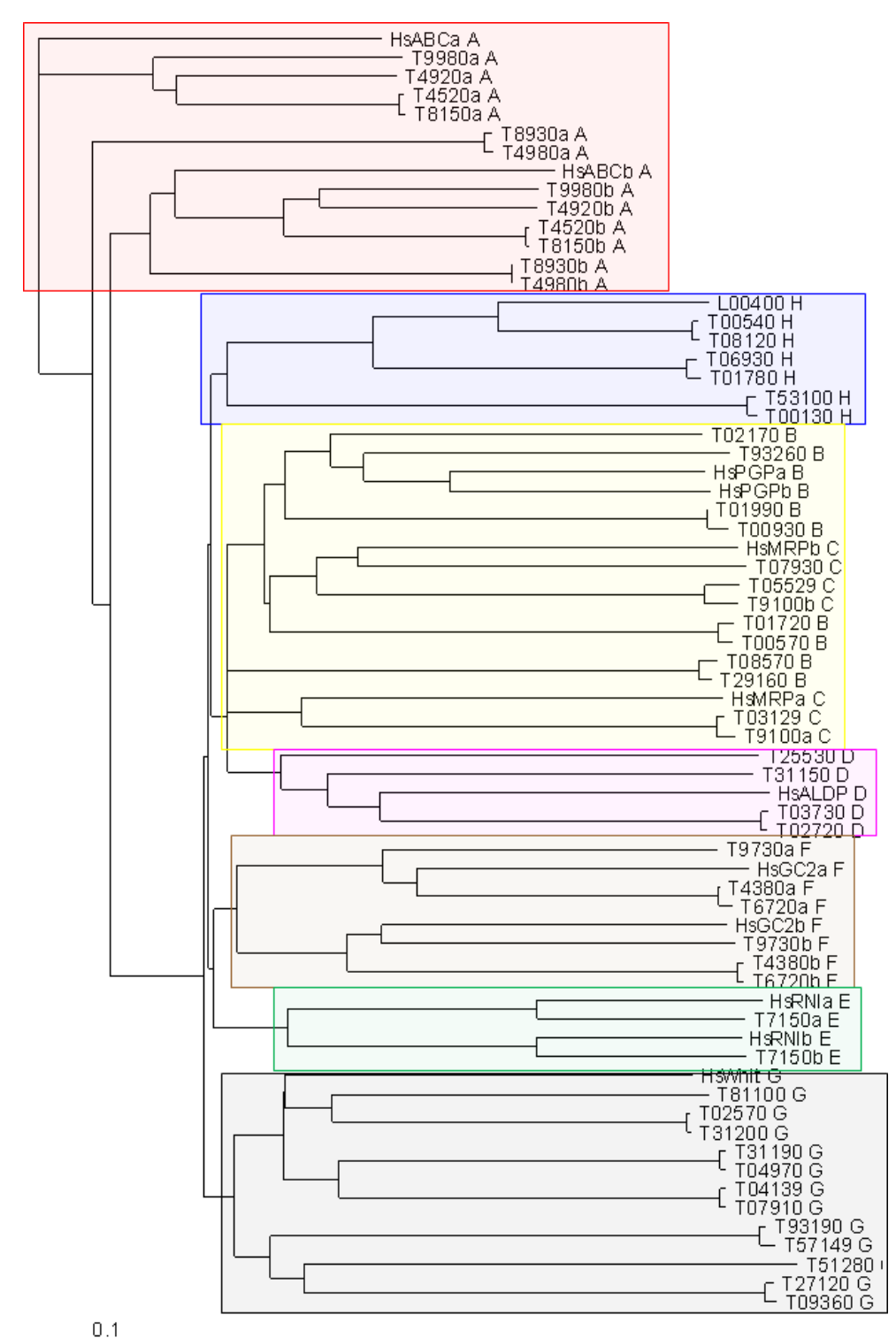

Figura 14 - Árvore de transportadores ABC de T. cruzi gerada pelo método neighbor-joining. As sequências de aminoácidos de NBDs das proteínas de T. cruzi (indicadas com a letra T) foram alinhadas com NBDs de um representante de cada subfamília ABC (A-G) de humanos (indicadas com a letra $\mathrm{H}$ ) e de um membro da subfamília $\mathrm{H}$ de Leishmania (indicado com a letra L). Os cinco primeiros algarismos do código no Genbank de cada $\mathrm{ABC}$ (Tabela 13) foram escolhidos para a nomenclatura dos táxons. Os NBDs de transportadores completos foram tratados independentemente nas análises, e identificados com as letras "a" e "b". A distância relativa dos ramos medida pelo método de distância de Saitou e Nei é representada na parte inferior da figura. 
De acordo com a posição das sequências nos ramos das árvores e sua comparação com a posição das sequências de $\mathrm{ABCs}$ humanos e de L. major, os transportadores $\mathrm{ABC}$ de $T$. cruzi foram avaliados com relação à porcentagem de similaridade com estas sequências de referência e finalmente classificados em subfamílias segundo as recomendações da $H U G O$ Gene Nomenclature Committee para genes ABC (Tabela 13). Concluímos a seguinte distribuição das subfamílias de CL Brener (Figura 15): A (14\%), B (21\%), C (10\%), D (7\%), E (3\%), F (7\%), G (21\%) e H (10\%).

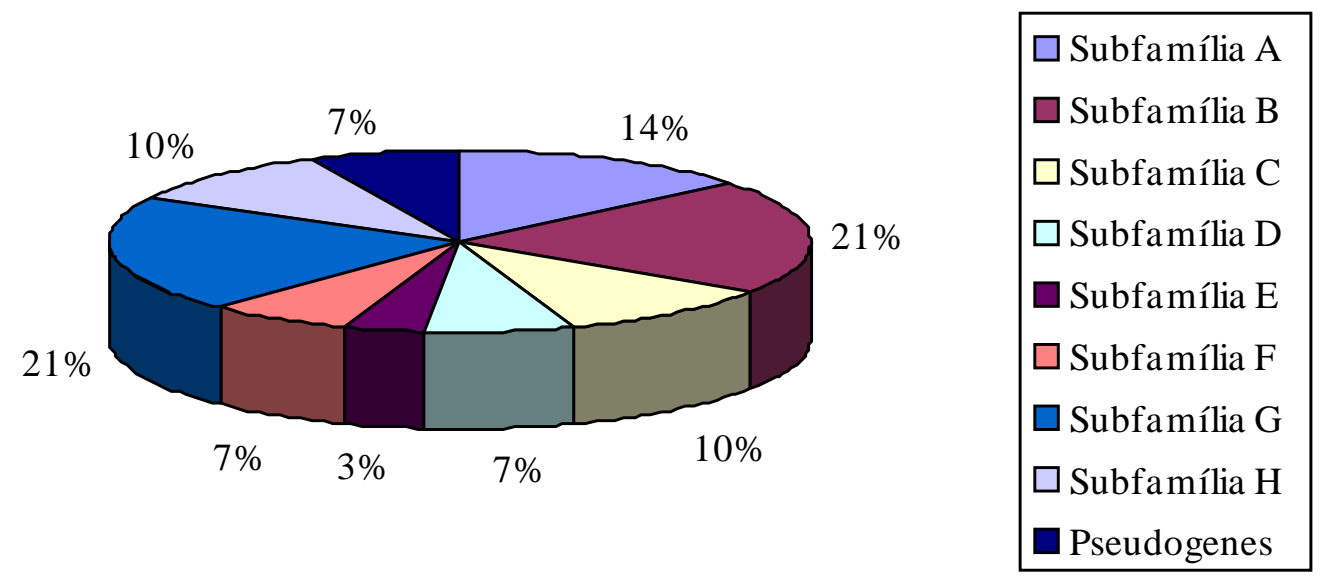

Figura 15 - Subfamílias de transportadores ABC de T. cruzi $(n$ amostral $=58)$. 


\section{DISCUSSÃO}

\subsection{Suscetibilidade a $\mathrm{BZ}$ e o efeito de inibidores de transportadores $\mathrm{ABC}$}

O grau de suscetibilidade a BZ determinado em nosso trabalho in vitro para formas epimastigotas (valor da $\mathrm{CI}_{50}$ ) teve concordância com o sucesso terapêutico in vivo determinado por Filardi e Brener (1987). As três cepas consideradas pelos autores como resistentes em modelos murinos (VL10, Colombiana e $\mathrm{YuYu}$ ), apresentaram valores de $\mathrm{CI}_{50}$ para BZ maiores que aqueles das duas cepas consideradas suscetíveis (CL Brener e Berenice 62). Para o clone Silvio, os dados, aparentemente, são discrepantes, mas a possível justificativa para este fato foi apresentada em Resultados. Em nosso trabalho, a cepa Silvio X10 cl1 foi considerada resistente a BZ, e abreviada como Silvio.

Os três estágios do ciclo evolutivo de $T$. cruzi têm sido usados em testes in vitro de suscetibilidade a drogas. Apesar de a forma amastigota intracelular ser considerada o estágio mais consistente para medidas da atividade de compostos tripanocidas in vivo, dados da literatura indicam uma forte correlação qualitativa entre a atividade destes compostos em formas epimastigotas de determinada cepa e em camundongos infectados com a mesma cepa (Urbina, 2009). Vale ressaltar, no entanto, que foram relatadas diferenças de algumas ordens de grandeza entre os valores de $\mathrm{CI}_{50}$ para formas epimastigotas e amastigotas.

Moreno e colaboradores constataram que ensaios in vitro com BZ não predizem o sucesso terapêutico com esta droga em pacientes tratados (Moreno et al., 2010). A busca pela melhoria do tratamento etiológico, utilizando-se como ferramenta testes de suscetibilidade in vitro, ainda permanece um desafio. A crítica mais pertinente de alguns especialistas contra o uso das formas epimastigotas em testes in vitro seria o fato de que estas formas não são infectivas para o hospedeiro humano e sua suscetibilidade a BZ não refletiria a suscetibilidade dos outros estágios (tripomastigotas e amastigotas) no homem. Por outro lado, dados do nosso grupo e de outros reforçam a hipótese de que o sucesso terapêutico dependa da interação entre três fatores principais: a suscetibilidade do parasita à droga tripanocida, o acesso da droga e seu acúmulo em diferentes ambientes celulares e teciduais, e a resposta imune do hospedeiro. Estes parâmetros dependem de investigações mais aprofundadas para o entendimento da atividade tripanocida de $\mathrm{BZ}$ e o desenvolvimento racional de novos compostos contra a doença de Chagas.

Em função de dados preliminares de nosso grupo, que apontam o possível envolvimento de um transportador $\mathrm{ABC}$ da subfamília $\mathrm{G}$ (TcABCG1) no fenótipo de 
resistência a BZ (Moreno Vigo, 2008), no presente trabalho analisamos o efeito de inibidores de transportadores $A B C$ na reversão desse fenótipo. Priorizamos os inibidores cuja ação foi previamente comprovada em diferentes subfamílias de $\mathrm{ABC}$ de outros organismos (revisto por Doyle e Ross, 2003; Ejendal e Hrycyna, 2004; Hiroyuki e Sugiyama, 2007; Qadir et al., 2005; Robey et al., 2008).

Dos três inibidores ensaiados: verapamil, ciclosporina A e fumitremorgin $\mathrm{C}$, apenas verapamil diminuiu a $\mathrm{CI}_{50}$ para $\mathrm{BZ}$, aumentando, portanto, a sensibilidade a esta droga. Este efeito foi observado em cepas suscetíveis e resistentes BZ e foi dependente da concentração de verapamil utilizada (20 e $30 \mu \mathrm{M}$, Tabela 6). A ação do verapamil na modulação da atividade de efluxo de drogas mediada por transportadores ABC de Leishmania foi investigada por vários autores. A resistência à pentamidina, importante leishmanicida, pôde ser revertida pelo uso de concentrações não tóxicas de verapamil em promastigotas de $L$. mexicana (Basselin et al., 2002) e em formas intracelulares de três espécies de Leishmania (Coelho et al., 2003, 2007). A combinação de pentamidina e concentração fixa de verapamil aumentou a suscetibilidade de amastigotas à pentamidina em L. major (15 $\mu \mathrm{M}$ de verapamil), L. amazonenis $(15 \mu \mathrm{M}$ de verapamil) e L. infantum $(20 \mu \mathrm{M}$ de verapamil) em 37\%, 59\% e $53 \%$, respectivamente (Coelho et al., 2007). Este efeito é análogo àquele por nós determinado para cepas de T. cruzi.

Assim como observado no presente estudo para T. cruzi, a ciclosporina A não atua no fenótipo de resistência a drogas em Leishmania (Coelho et al., 2003, 2007), apesar de sua ação moduladora ter sido documentada em Criptosporidium parvum (Bonafonte et al., 2004), Plasmodium falciparum (Galvigan et al., 2007) e Toxoplasma gondii (Sauvage et al., 2004), dentre outros parasitas.

Em Leishmania, o efeito de fumitremorgin C não foi investigado. A subfamília $\mathrm{G}$ dos transportadores $\mathrm{ABC}$ apresenta cinco membros (ABCG1, ABCG2, ABCG4, ABCG5, e ABCG8). Apenas para os transportadores ABCG2, dos quais a BCRP (breast cancer resistance protein) é o transportador mais estudado, a atividade inibitória de fumitremorgin $\mathrm{C}$ está bem documentada (revisto em Hiroyuki e Sugiyama, 2007). Em nossas análises de similaridade da sequência de aminoácidos do transportador TcABCG1 com transportadores ABC dos cinco membros da subfamília G de Homo sapiens, L. major e L. infantum (Tabela 2 da Introdução), verificamos que o transportador de T. cruzi apresenta uma similaridade de cerca $57-60 \%$ com o transportador ABCG2 de Leishmania e uma similaridade $29 \%$ com o transportador $\mathrm{ABCG} 2$ de humanos. $\mathrm{O}$ fato de fumitremorgin $\mathrm{C}$ não ter aumentado a suscetibilidade a BZ em $T$. cruzi não afasta a hipótese de que um transportador da subfamília 
G esteja envolvido na resistência a esta droga. Desta forma, inibidores específicos para transportadores ABCG de protozoários deverão ser buscados.

\subsection{Cópias do gene $T c A B C G 1$ em cepas de $T$. cruzi}

Em espécies de Leishmania, cuja resistência a metotrexato foi induzida por pressão seletiva com a droga, foi observada o aumento da amplificação do gene de um transportador ABC (pgpA), no DNA extracromossômico (Ouellette et al., 1990). Nós investigamos a possibilidade de haver maior amplificação do gene TcABCGl em cepas de T. cruzi naturalmente resistentes a BZ (VL10, YuYu e Colombiana). Utilizando ensaios de PCR em tempo real, concluímos não haver diferenças na abundância relativa do número de cópias do gene nas cepas sensíveis e resistentes à droga.

\subsection{Estrutura do gene TcABCG1 de cepas de $T$. cruzi}

O gene TcABCG1 das cepas Berenice 62, Silvio, VL10 e YuYu foi clonado e sua sequência comparada com a dos haplótipos Esmo e Não Esmo de CL Brener. Inicialmente observamos 41 variações nucleotídicas entre os dois haplótipos de CL Brener (Figura A.1 no Anexo A), das quais 28 originam o mesmo aminoácido (mutações sinônimas); 6 promovem alteração do aminoácido, mas manutenção de sua polaridade e 7, alteração do aminoácido e de sua polaridade. Verificamos que o transportador de Berenice 62 e VL10 (ambas DTU TcII) tem sequência proteica idêntica àquela codificada pelo haplótipo Esmo de CL Brener, embora o gene das duas cepas apresente três mutações sinônimas. A identidade de aminoácidos do gene de VL10 e Berenice 62 com a do haplótipo Esmo de CL Brener é condizente com a origem evolutiva de CL Brener (TcVI) que seria um híbrido de cepas TcII e TcIII. Por sua vez, TcIII seria um híbrido de TcI e TcII, segundo vários autores (Elias et al., 2005; Ienne et al., 2010; Sturm e Campbell, 2010).

As sequências proteicas de TcABCG1 das cepas Silvio e YuYu (DTU TcI) são idênticas e diferenciam-se em 10 variações não-sinônimas de aminoácidos em relação à sequência Não Esmo de CL Brener. Este resultado é interessante e apoiaria a hipótese de que TcI seria um ancestral de TcIII que, por sua vez, seria ancestral de CL Brener. Sabe-se que um único SNP é capaz de alterar a funcionalidade do transportador ABCG2 (Morisaki et al., 2005; Yanase et al, 2006). Em nosso laboratório, em seu projeto de mestrado, Jaques Franco de Carvalho Júnior está analisando a sequência do gene TcABCG1 de várias cepas, 
representantes das diversas DTUs, para possível identificação de SNPs (Single Nucleotide Polymorphisms) e inferências filogenéticas.

A localização do gene $T c A B C G 1$ foi avaliada por Southern Blot de DNA genômico das cepas 115, Berenice 62, CL Brener, Colombiana, VL10 e YuYu digerido com HindIII e hibridizado com a sonda do gene ABC. Estruturalmente, o gene localiza-se em diferentes contextos no genoma destas cepas. Há um padrão distinto da estrutura do gene ABC entre os genomas dos pares CL Brener-115, Berenice-VL10 e Colombiana-YuYu (Figura A.2 no Anexo A).

\subsection{Transfecção do gene $T c A B C G 1$ de cepas de $T$. cruzi e análise da suscetibilidade a BZ e NFX}

A superexpressão de transportadores ABC por transfecção gênica tem sido obtida com sucesso em T. cruzi (Torres et al., 2004) e em espécies de Leishmania (Coelho et al., 2003; Do Monte-Neto et al., 2011; Leprohon et al., 2009).

Em base à análise da sequência proteica do transportador $\mathrm{ABC}$ das cepas, decidimos transfectar em CL Brener o gene TcABCG1 de três cepas resistentes a BZ: VL10 (TcII), Silvio (TcI) e YuYu (TcI). Transfectamos ainda o haplótipo Não Esmo de CL Brener a fim de comparar o efeito da transfecção com o gene de VL10 (haplótipo Esmo) e o vetor vazio. Todas as culturas transfectadas tiveram igual taxa de crescimento em meio contendo 200 $\mu \mathrm{g} / \mathrm{ml}$ de G418. Nas culturas transfectadas com o gene das cepas Silvio e YuYu observamos um aumento da resistência a BZ de 26 e 32\%, respectivamente, ao passo que nas culturas transfectadas com o haplótipo Não Esmo de CL Brener e gene de VL10 o aumento foi de cerca $10 \%$. Na transfecção com pROCK vazio o aumento foi de $2 \%$. O maior aumento da resistência a BZ promovido pelos genes das duas cepas da DTU TcI pode ser resultante de suas características estruturais (ver acima). Por outro lado, a transfecção do gene dessas cepas não promove o nível de resistência a BZ verificado nas cepas de origem. De fato, a análise dos dados de suscetibilidade a BZ das cepas (Tabela 4) mostra que a cepa Silvio e YuYu têm uma $\mathrm{CI}_{50}$ que é de 2 e 3 vezes maior, respectivamente, que a $\mathrm{CI}_{50}$ de $\mathrm{CL}$ Brener. Tendo em vista que transportadores da subfamília G necessitam dimerizar-se para exercer sua função, é possível que o transportador TcABCG1 de cepas TcI sofra uma dimerização parcial ou "híbrida" (TcI-CL Brener) no citoplasma de CL Brener. O fato de o gene TcABCG1 de TcI não promover em CL Brener o nível de resistência a BZ observado nas cepas TcI apoia a hipótese de que este transportador não seja o único elemento envolvido na resistência à droga. 
O fato de o gene de VL10 promover um aumento de resistência a BZ de apenas $10 \%$ foi intrigante. Desta forma, analisamos a localização do gene TcABCG1 no genoma dos parasitas transfectados. O conjunto dos dados de Southern blot sugeriu que nos parasitas transfectados o gene de VL10 teria se integrado em um lócus diferente do lócus onde os demais genes haviam se integrado. Uma possibilidade seria que este gene tenha se integrado no lócus do gene TcABCG1 de CL Brener, substituindo-o.

Para verificar se uma ou ambas as cópias do gene de CL Brener haviam sido substituídas, clonamos o gene TcABCG1 da cultura transfectada com o gene de VL10 (dados não mostrados). Dos 8 clones sequenciados, verificamos que 3 clones apresentavam a sequência de VL10, 3 clones, do haplótipo Não Esmo de CL Brener e 2 clones, do haplótipo Esmo. Estes resultados indicam que as três cópias gênicas estariam presentes no genoma de CL Brener transfectado. Isto também ocorreria na cepa transfectada com o haplótipo Não Esmo de CL Brener. O fato de as cepas transfectadas com o gene de VL10 e de CL Brener terem um aumento de $10 \%$ da $\mathrm{CI}_{50}$ para $\mathrm{BZ}$, menor que o aumento verificado com o gene das cepas TcI, fala a favor de diferenças nas características estruturais dos transportadores $\mathrm{ABC}$ desta DTU. Estudos adicionais deverão ser realizados para o melhor entendimento do local de integração dos genes, como a análise de sua localização cromossômica por PFGE.

Nos transfectantes também verificamos aumento da $\mathrm{CI}_{50}$ para NFX. Isto seria sugestivo de o transportador $\mathrm{ABC}$ também promover o efluxo de outra droga nitroheterocíclica. Este aspecto também deverá ser explorado futuramente. Por outro lado, não temos explicação para o fato de o gene de VL10 promover um incremento da $\mathrm{CI}_{50}$ para NFX muito maior em relação àquele promovido pelos genes das outras cepas.

\subsection{Abundância de transcritos de $T c A B C G 1$ nos transfectantes}

A abundância relativa de transcritos do gene ABC foi avaliada por RT-PCR em tempo real nas cepas transfectadas. Atribuindo o valor unitário para a abundância de transcritos na cepa CL Brener não transfectada, verificamos que nas culturas transfectadas com os genes de CL Brener, Silvio e YuYu houve um incremento de transcritos de 2,70; 2,85; e 2,67 vezes. Na cultura transfectada com o gene de VL10 a abundância de transcritos teve um valor próximo ao valor obtido para as culturas de CL Brener WT e transfectada com o vetor vazio. Esta observação reforça a hipótese que neste transfectante o gene esteja numa região diferente do genoma, quando comparado com os demais genes transfectados. 
Analisando-se a abundância relativa dos transcritos do gene $\mathrm{ABC}$ nos transfectantes, observa-se que não ultrapassam o valor de 3. Em diversos trabalhos, onde microarranjos de DNA foram utilizados para avaliar a expressão gênica em tripanossomatídios, raramente a razão de hibridização do cDNA entre estágios evolutivos ou cepas ultrapassa o valor de 3 (ver por exemplo Baptista et al., 2004; Minning et al., 2003). Esta característica reflete o mecanismo de controle da expressão gênica dos Kinetoplastida, nos quais as ORFs estão dispostas em arranjos policistrônicos longos e mRNAs monocistrônicos são originados por processamento pós-transcricional (revisto em Clayton e Shapira, 2007). A estabilidade dos transcritos está relacionada, preferencialmente, ao tipo de sequências localizadas na região 3'UTR (revisto em Clayton e Shapira, 2007). Em nosso estudo, transfectamos apenas as ORFs do gene ABC das cepas. É possível que as UTRs dos genes de cada cepa tenham características específicas que lhes confiram maior estabilidade e, desta forma, sua abundância e tradução sejam superiores nas cepas originais. Este aspecto também deverá ser explorado. Outra possibilidade é a de utilizar para a transfecção vetores que não se integram no genoma do parasita e que promovam expressão transitória do gene de interesse.

\subsection{Filogenia de transportadores $\mathrm{ABC}$ de $T$. cruzi}

No presente trabalho identificamos, caracterizamos e classificamos 58 genes de CL Brener codificadores de proteínas ABC hipotéticas. Nas análises filogenéticas, os transportadores $\mathrm{ABC}$ das subfamílias A, D, E, F, G e H formaram grupos monofiléticos. Em nossa árvore construída pelo método de neighbor-joining (Figura 14), os membros da subfamília $\mathrm{G}$, dentre os quais se encontram o TcABCG1, formaram um clado bem definido e seguramente separado dos demais clados. Por outro lado, os transportadores ABCB e ABCC ficaram reunidos no mesmo agrupamento. Neste caso, a filogenia avaliada a partir de sequências de aminoácidos entre os membros ABCB e ABCC de T. cruzi e membros ABCB e $\mathrm{ABCC}$ de humanos precisaria ser aprimorada para separar estes transportadores em grupos monofiléticos distintos.

Foi interessante verificar o número relativamente elevado de transportadores $\mathrm{ABC}$ (58) no genoma de T. cruzi, em comparação com os 48 ABC presentes no genoma humano (Dean e Anillo, 2005), evidenciando sua importância no organismo deste protozoário. Transportadores das subfamílias $\mathrm{B}, \mathrm{C}$ e $\mathrm{G}$, sabidamente relacionados à resistência a multidrogas, compõem $52 \%$ do total de ABC encontrados. Um maior estudo sobre outros 
membros especificamente pertencentes a estas três subfamílias certamente elucidará ainda mais os mecanismos de transporte de drogas por transportadores $\mathrm{ABC}$.

As análises filogenéticas deverão ser mais aprofundadas através de filogenia usando análise Bayesina (MrBayes) e análise de rede (Network) em colaboração com a professora Renata Carmona e Ferreira (Departamento de Microbiologia e Imunologia/UNIFESP). Pretendemos contribuir com a identificação e a anotação completa no Genbank de todos os transportadores ABC presentes organismo da cepa CL Brener de T. cruzi. Estas informações, juntamente com o estudo da função de transportadores $\mathrm{ABC}$, poderão futuramente fornecer novas informações sobre o papel destes transportadores na biologia do parasita e na resistência a drogas.

\subsection{Perspectivas}

$\mathrm{Na}$ continuidade do projeto, um fator importante de regulação que certamente deverá ser explorado refere-se ao efeito das modificações pós-traducionais da proteína do transportador TcABCG1 em sua função e eficiência de transporte. Verificamos, em nossas análises, sítios de modificações pós-traducionais na sequência de aminoácidos da proteína ABC de CL Brener, VL10, Silvio e YuYu, como sítios de fosforilação em serina, treonina e tirosina, de glicolização, de acetilação e de metilação (Figura A.3 no Anexo A). Alguns sítios de fosforilação diferenciam as sequências em relação à cepa referência (haplótipo Não-Esmo de CL Brener) e tais modificações poderiam estar ligadas a alterações na atividade de transporte de drogas por estas proteínas.

Nas duas últimas décadas, a divulgação de diferentes alelos relacionados à resistência a drogas tem impactado a epidemiologia de várias doenças parasitárias, alterando as opções de tratamento. Um estudo extenso realizado no oeste africano, mostrou que a falha terapêutica no tratamento da malária com cloroquina é determinado pela presença de um alelo de um transportador ABC de Plasmodium falciparum ( $p f c r t$ ), no qual há uma substituição de lisina por treonina no códon de posição 76 (Gavigan et al., 2007). O nível de resistência é também modulado por outro transportador, codificado pelo gene $p f m d r l$, onde uma mutação promove o aparecimento de tirosina no códon 86 (revisto em Conway, 2007). Em face à resistência a cloroquina, o tratamento da malária com drogas de nova geração tem sido adotado em vários países africanos, como a combinação entre sulfodoxina e pirimetamina (revisto em Conway, 2007). 
Várias drogas tripanocidas estão em desenvolvimento com resultados promissores, tais como inibidores da síntese de hipoxantina-guanina fosforribosil transferase, de bisfosfonatos e do ergosterol. Alguns compostos encontram-se em testes pré-clínicos e seu potencial no desenvolvimento clínico é esperado de médio a longo prazo (10-15 anos) (revisto em Urbina, 2009). A razão para o desenvolvimento relativamente lento de novas drogas para o tratamento da doença de Chagas deve-se claramente à falta de incentivos econômicos para a pesquisa por novos medicamentos nos laboratórios e em indústrias farmacêuticas investigacionais. No início da década de 2000, o custo estimado para a introdução de uma nova droga no mercado farmacêutico era de aproximadamente 800 milhões de dólares (Preziosi, 2004), e dados mais recentes colocam este valor acima de um bilhão (revisto em Pronker et al., 2011) (Figura 16). A busca de maior apoio para a pesquisa básica sobre os mecanismos de resistência a drogas e para a investigação de novas drogas para o tratamento da doença de Chagas, em particular, e de doenças negligenciadas, em geral, é de fundamental importância.

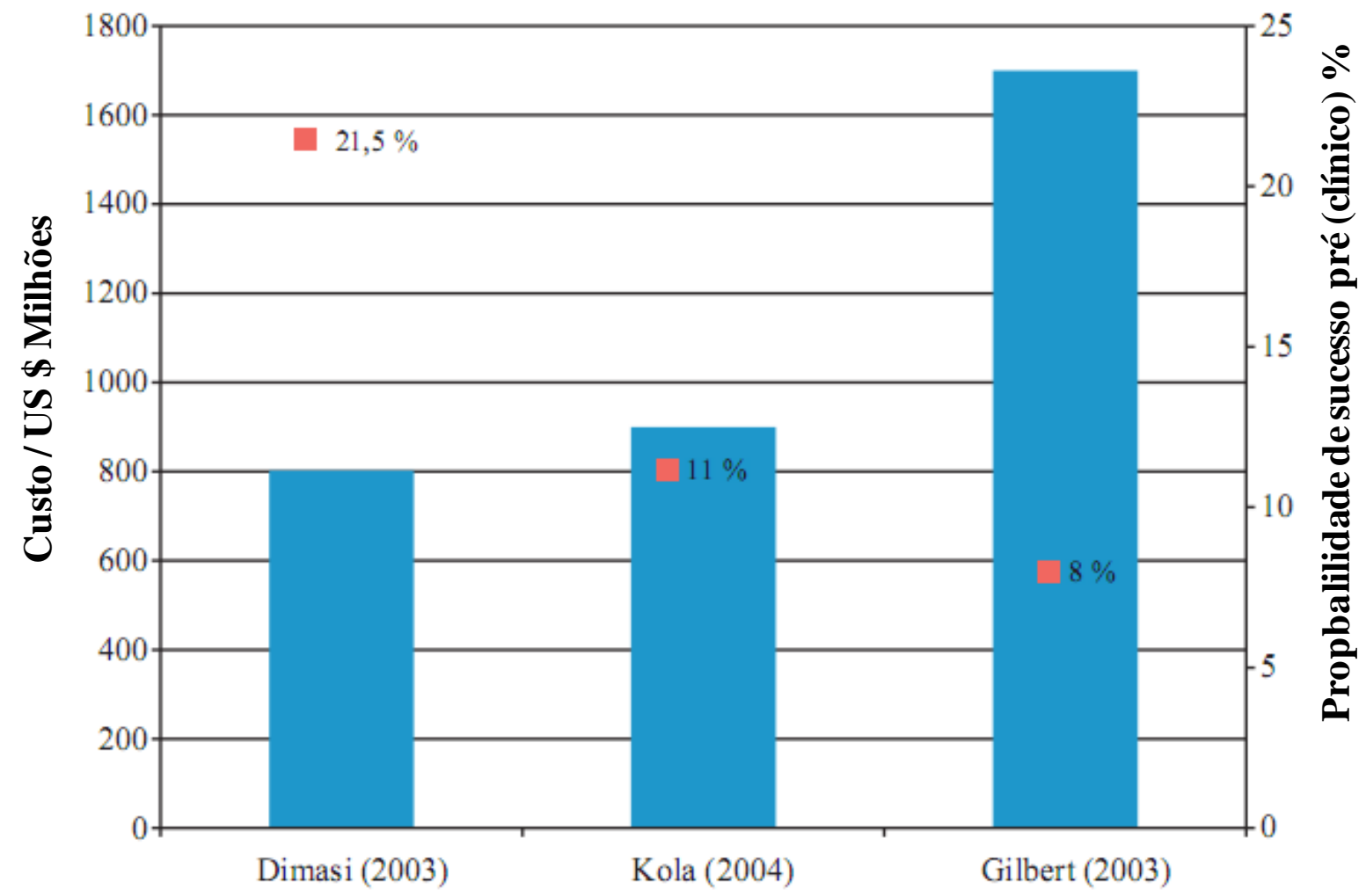

Figura 16 - Investimento cumulativo para obter-se uma nova droga. Todos os custos excluem investimentos em vacinas. O gráfico não mostra uma tendência. São apresentados três custos e cálculos de riscos independentes (extraído de Pronker et al., 2011).

Os dados apresentados neste trabalho apoiam a hipótese de que o transportador TcABCG1 seja um dos elementos envolvidos na resistência a drogas nitro-heterocíclicas. Um 
estudo mais abrangente sobre a presença de variações alélicas entre cepas sensíveis e resistentes, localização e abundância celular do transportador está em andamento em nosso laboratório. Estes dados poderão ser utilizados para a identificação de cepas resistentes ao tratamento com as duas drogas disponíveis. O mapeamento recente de genes de resistência a drogas em populações de Plasmodium, Leishmania e Trypanosoma fornece uma perspectiva otimista para estudos de análise de polimorfismos genéticos e detecção de alelos gênicos, que poderão ser utilizados como potentes ferramentas no diagnóstico diferencial em pacientes infectados. A escolha do tratamento mais indicado para cada paciente poderá ser facilitada pela identificação do tipo populacional do parasita infectante, cujos mecanismos de resistência a uma determinada droga possuem grande variação até mesmo entre populações da mesma espécie. 


\section{REFERÊNCIAS $^{1}$}

Andrade SG, Rassi A, Magalhaes JB, Ferriolli Filho F, Luquetti AO. Specific chemotherapy of Chagas disease: a comparison between the response in patients and experimental animals inoculated with the same strains. Trans R Soc Trop Med Hyg. 1992 Nov-Dec;86(6):624-6.

Altschul SF, Madden TL, Schaffer AA, Zhang J, Zhang Z, Miller W, et al. Gapped BLAST and PSI-BLAST: a new generation of protein database search programs. Nucleic Acids Res. 1997 Sep 1;25(17):3389-402.

Azoles E1224 \& Biomarker (Chagas), 2011. Available from: http://www.dndi.org/portfolio/azoles-e1224-and-biomarker.html [2011 Sep 5].

Baptista CS, Vencio RZ, Abdala S, Valadares MP, Martins C, de Braganca Pereira CA, et al. DNA microarrays for comparative genomics and analysis of gene expression in Trypanosoma cruzi. Mol Biochem Parasitol. 2004 Dec;138(2):183-94.

Barrett MP, Fairlamb AH. The biochemical basis of arsenical-diamidine crossresistance in African trypanosomes. Parasitol Today. 1999 Apr;15(4):136-40.

Basselin M, Denise H, Coombs GH, Barrett MP. Resistance to pentamidine in Leishmania mexicana involves exclusion of the drug from the mitochondrion. Antimicrob Agents Chemother. 2002 Dec;46(12):3731-8.

Bateman A, Coin L, Durbin R, Finn RD, Hollich V, Griffiths-Jones S, et al. The Pfam protein families database, 2004. Available from: http://pfam.sanger.ac.uk/ [2011 Sep 5].

Benaim G, Sanders JM, Garcia-Marchan Y, Colina C, Lira R, Caldera AR, et al. Amiodarone has intrinsic anti-Trypanosoma cruzi activity and acts synergistically with posaconazole. J Med Chem. 2006 Feb 9;49(3):892-9.

Berman HM, Westbrook J, Feng Z, Gilliland G, Bhat TN, Weissig H, Shindyalov IN, Bourne PE. The Protein Data Bank, 2000. Available from: http://www.pdb.org [2011 Sep 5].

Bonafonte MT, Romagnoli PA, McNair N, Shaw AP, Scanlon M, Leitch GJ, et al. Cryptosporidium parvum: effect of multi-drug reversing agents on the expression and function of ATP-binding cassette transporters. Exp Parasitol. 2004 Mar-Apr;106(3-4):126-34.

Brener Z. Biology of Trypanosoma cruzi. Annu Rev Microbiol. 1973;27:347-82.

Cancado JR. Etiological treatment of chronic Chagas disease. Rev Inst Med Trop Sao Paulo. 2001 May-Jun;43(3):173-81.

\footnotetext{
${ }^{1}$ International Comittee of Medical Journal Editors. Uniform requirements for manuscripts submitted to Biomedical Journal: sample references. Available from http://www.icmje.org [2007 May 22].
} 
Castanys-Muñoz E, Alder-Baerens N, Pomorski T, Gamarro F, Castanys S. A novel ATPbinding cassette transporter from Leishmania is involved in transport of phosphatidylcholine analogues and resistance to alkyl-phospholipids. Mol Microbiol. 2007 Jun;64(5):1141-53.

Castanys-Munoz E, Perez-Victoria JM, Gamarro F, Castanys S. Characterization of an ABCG-like transporter from the protozoan parasite Leishmania with a role in drug resistance and transbilayer lipid movement. Antimicrob Agents Chemother. 2008 Oct;52(10):3573-9.

Castellani O, Ribeiro LV, Fernandes JF. Differentiation of Trypanosoma cruzi in culture. J Protozool. 1967 Aug;14(3):447-51.

Castro JA, de Mecca MM, Bartel LC. Toxic side effects of drugs used to treat Chagas' disease (American trypanosomiasis). Hum Exp Toxicol. 2006 Aug;25(8):471-9.

CDC's Division of Parasitic Disiases and Malaria (DPDM), 2010. Available from: http://www.dpd.cdc.gov/dpdx/HTML/TrypanosomiasisAmerican.htm [2011 Sep 5].

Clayton C, Shapira M. Post-transcriptional regulation of gene expression in trypanosomes and Leishmanias. Mol Biochem Parasitol. 2007 Dec;156(2):93-101.

Chen F, Mackey AJ, Stoeckert CJ, Jr., Roos DS. OrthoMCL-DB: querying a comprehensive multi-species collection of ortholog groups. Nucleic Acids Res. 2006 Jan 1;34(Database issue):D363-8.

Chow LM, Wong AK, Ullman B, Wirth DF. Cloning and functional analysis of an extrachromosomally amplified multidrug resistance-like gene in Leishmania enriettii. Mol Biochem Parasitol. 1993 Aug;60(2):195-208.

Coelho AC, Beverley SM, Cotrim PC. Functional genetic identification of PRP1, an ABC transporter superfamily member conferring pentamidine resistance in Leishmania major. Mol Biochem Parasitol. 2003 Aug 31;130(2):83-90.

Coelho AC, Messier N, Ouellette M, Cotrim PC. Role of the ABC transporter PRP1 (ABCC7) in pentamidine resistance in Leishmania amastigotes. Antimicrob Agents Chemother. 2007 Aug;51(8):3030-2.

Coelho AC, Gentil LG, da Silveira JF, Cotrim PC. Characterization of Leishmania (Leishmania) amazonensis promastigotes resistant to pentamidine. Exp Parasitol. 2008 Sep;120(1):98-102.

Conway DJ. Molecular epidemiology of malaria. Clin Microbiol Rev. 2007 Jan;20(1):188204.

Corrales M, Cardozo R, Segura MA, Urbina JA, Basombrio MA. Comparative efficacies of TAK-187, a long-lasting ergosterol biosynthesis inhibitor, and benznidazole in preventing cardiac damage in a murine model of Chagas' disease. Antimicrob Agents Chemother. 2005 Apr;49(4):1556-60.

Coura JR, Castro SL. A critical review on Chagas disease chemotherapy. Mem Inst Oswaldo Cruz. 2002 Jan;97(1):3-24. 
Dallagiovanna B, Castanys S, Gamarro F. Trypanosoma cruzi: sequence of the ATP-binding site of a P-glycoprotein gene. Exp Parasitol. 1994 Aug;79(1):63-7.

Dallagiovanna B, Gamarro F, Castanys S. Molecular characterization of a P-glycoproteinrelated tcpgp2 gene in Trypanosoma cruzi. Mol Biochem Parasitol. 1996 Jan;75(2):145-57.

DaRocha WD, Silva RA, Bartholomeu DC, Pires SF, Freitas JM, Macedo AM, et al. Expression of exogenous genes in Trypanosoma cruzi: improving vectors and electroporation protocols. Parasitol Res. 2004 Jan;92(2):113-20.

De Andrade AL, Zicker F, de Oliveira RM, Almeida Silva S, Luquetti A, Travassos LR, et al. Randomised trial of efficacy of benznidazole in treatment of early Trypanosoma cruzi infection. Lancet. 1996 Nov 23;348(9039):1407-13.

De Diego JA, Palau MT, Gamallo C, Penin P. Relationships between histopathological findings and phylogenetic divergence in Trypanosoma cruzi. Trop Med Int Health. 1998 Mar;3(3):222-33.

De Freitas JM, Augusto-Pinto L, Pimenta JR, Bastos-Rodrigues L, Goncalves VF, Teixeira SM, et al. Ancestral genomes, sex, and the population structure of Trypanosoma cruzi. PLoS Pathog. 2006 Mar;2(3):e24.

De Souza EM, Araujo-Jorge TC, Bailly C, Lansiaux A, Batista MM, Oliveira GM, et al. Host and parasite apoptosis following Trypanosoma cruzi infection in in vitro and in vivo models. Cell Tissue Res. 2003 Nov;314(2):223-35.

De Souza EM, da Silva PB, Nefertiti AS, Ismail MA, Arafa RK, Tao B, et al. Trypanocidal activity and selectivity in vitro of aromatic amidine compounds upon bloodstream and intracellular forms of Trypanosoma cruzi. Exp Parasitol. 2011 Feb;127(2):429-35.

De Toranzo EG, Castro JA. Reaction of 4-hydroxynonenal with some thiol-containing radioprotective agents or their active metabolites. Free Radic Biol Med. 1994 Dec;17(6):6057.

Dean M, Annilo T. Evolution of the ATP-binding cassette (ABC) transporter superfamily in vertebrates. Annu Rev Genomics Hum Genet. 2005;6:123-42.

Dias JC. Epidemiological surveillance of Chagas disease. Cad Saude Publica. 2000;16 (Suppl 2):43-59.

Dias JC. Notes about of Trypanosoma cruzi and yours bio-ecology characteristics with agents of the transmission by meals. Rev Soc Bras Med Trop. 2006 Jul-Aug;39(4):370-5.

Doyle LA, Yang W, Abruzzo LV, Krogmann T, Gao Y, Rishi AK, et al. A multidrug resistance transporter from human MCF-7 breast cancer cells. Proc Natl Acad Sci U S A. 1998 Dec 22;95(26):15665-70.

Doyle LA, Ross DD. Multidrug resistance mediated by the breast cancer resistance protein BCRP (ABCG2). Oncogene. 2003 Oct 20;22(47):7340-58. 
Ejendal KF, Hrycyna CA. Differential sensitivities of the human ATP-binding cassette transporters ABCG2 and P-glycoprotein to cyclosporin A. Mol Pharmacol. 2005 Mar;67(3):902-11.

El-Sayed NM, Myler PJ, Bartholomeu DC, Nilsson D, Aggarwal G, Tran AN, et al. The genome sequence of Trypanosoma cruzi, etiologic agent of Chagas disease. Science. $2005 \mathrm{Jul}$ 15;309(5733):409-15.

Elias MC, Vargas N, Tomazi L, Pedroso A, Zingales B, Schenkman S, et al. Comparative analysis of genomic sequences suggests that Trypanosoma cruzi CL Brener contains two sets of non-intercalated repeats of satellite DNA that correspond to T. cruzi I and T. cruzi II types. Mol Biochem Parasitol. 2005 Apr;140(2):221-7.

Fidock DA, Nomura T, Talley AK, Cooper RA, Dzekunov SM, Ferdig MT, et al. Mutations in the $P$. falciparum digestive vacuole transmembrane protein PfCRT and evidence for their role in chloroquine resistance. Mol Cell. 2000 Oct;6(4):861-71.

Filardi LS, Brener Z. Susceptibility and natural resistance of Trypanosoma cruzi strains to drugs used clinically in Chagas disease. Trans R Soc Trop Med Hyg. 1987;81(5):755-9.

Finn RD, Mistry J, Tate J, Coggill P, Heger A, Pollington JE, et al. The Pfam protein families database. Nucleic Acids Res. 2010 Jan;38(Database issue):D211-22.

Floeter-Winter LM, Souto RP, Stolf BS, Zingales B, Buck GA. Trypanosoma cruzi: can activity of the rRNA gene promoter be used as a marker for speciation? Exp Parasitol. 1997 $\mathrm{Jul} ; 86(3): 232-4$.

Foote SJ, Thompson JK, Cowman AF, Kemp DJ. Amplification of the multidrug resistance gene in some chloroquine-resistant isolates of $P$. falciparum. Cell. 1989 Jun 16;57(6):921-30.

Gavigan CS, Shen M, Machado SG, Bell A. Influence of the Plasmodium falciparum Pglycoprotein homologue 1 (pfmdr1 gene product) on the antimalarial action of cyclosporin. $\mathbf{J}$ Antimicrob Chemother. 2007 Feb;59(2):197-203.

Germann UA. P-glycoprotein--a mediator of multidrug resistance in tumour cells. Eur J Cancer. 1996 Jun;32A(6):927-44.

Gorla N, Diaz Gomez MI, Castro JA. Interaction of benznidazole reactive metabolites with rat liver deoxyribonucleic acid and nuclear proteins. Arch Int Pharmacodyn Ther. 1986 Mar;280(1):22-31.

Gueiros-Filho FJ, Viola JP, Gomes FC, Farina M, Lins U, Bertho AL, et al. Leishmania amazonensis: multidrug resistance in vinblastine-resistant promastigotes is associated with rhodamine 123 efflux, DNA amplification, and RNA overexpression of a Leishmania mdr1 gene. Exp Parasitol. 1995 Dec;81(4):480-90.

Hall TA. Bioedit: a user-friendly biological sequence alignment editor and analysis program for Windows 95/98/NT. Nucleic Acids Symp Ser. 1999; 41:95-98. 
Henderson DM, Sifri CD, Rodgers M, Wirth DF, Hendrickson N, Ullman B. Multidrug resistance in Leishmania donovani is conferred by amplification of a gene homologous to the mammalian mdr1 gene. Mol Cell Biol. 1992 Jun;12(6):2855-65.

Higgins CF, Linton KJ. The ATP switch model for ABC transporters. Nat Struct Mol Biol. 2004 Oct;11(10):918-26.

Higgins CF. Multiple molecular mechanisms for multidrug resistance transporters. Nature. 2007 Apr 12;446(7137):749-57.

HUGO Gene Nomenclature Committee (HGNC) [homepage on internet]. Department of Biology, University College London, Wolfson House, 4 Stephenson Way, London NW1 2HE, UK. Available from: http://www.genenames.org/genefamilies/ABC. [2011 Sep 4].

Ienne S, Pedroso A, Carmona EFR, Briones MR, Zingales B. Network genealogy of 195-bp satellite DNA supports the superimposed hybridization hypothesis of Trypanosoma cruzi evolutionary pattern. Infect Genet Evol. 2010 Jul;10(5):601-6.

ImageJ - Image Processing and Analysis in Java from National Institutes of Health., 2004. Available from: http://imagej.nih.gov/ij [2011 Sep 5].

Imai Y, Tsukahara S, Ishikawa E, Tsuruo T, Sugimoto Y. Estrone and 17beta-estradiol reverse breast cancer resistance protein-mediated multidrug resistance. Jpn J Cancer Res. 2002 Mar;93(3):231-5.

Ishikawa T, Allikmets R, Dean M, Higgins C, Ling V and Wain HM. New nomenclature of human ABC transporter genes Xenobiotics, Metabolism and Disposition. 2000. Available from: http://www.genenames.org/genefamilies/ABC [2011 Sep 5].

Kusuhara H, Sugiyama Y. ATP-binding cassette, subfamily G (ABCG family). Pflugers Arch. 2007 Feb;453(5):735-44.

Krogstad DJ, Gluzman IY, Kyle DE, Oduola AM, Martin SK, Milhous WK, et al. Efflux of chloroquine from Plasmodium falciparum: mechanism of chloroquine resistance. Science. 1987 Nov 27;238(4831):1283-5.

Lage H. ABC-transporters: implications on drug resistance from microorganisms to human cancers. Int J Antimicrob Agents. 2003 Sep;22(3):188-99.

Lee JH, Uhl JR, Cockerill FR, 3rd, Weaver AL, Orvidas LJ. Real-time PCR vs standard culture detection of group A beta-hemolytic streptococci at various anatomic sites in tonsillectomy patients. Arch Otolaryngol Head Neck Surg. 2008 Nov;134(11):1177-81.

Leprohon P, Legare D, Girard I, Papadopoulou B, Ouellette M. Modulation of Leishmania $\mathrm{ABC}$ protein gene expression through life stages and among drug-resistant parasites. Eukaryot Cell. 2006 Oct;5(10):1713-25.

Leprohon P, Legare D, Raymond F, Madore E, Hardiman G, Corbeil J, et al. Gene expression modulation is associated with gene amplification, supernumerary chromosomes and chromosome loss in antimony-resistant Leishmania infantum. Nucleic Acids Res. 2009 Apr;37(5):1387-99. 
Li L, Stoeckert CJ, Jr., Roos DS. OrthoMCL: identification of ortholog groups for eukaryotic genomes. Genome Res. 2003 Sep;13(9):2178-89.

Johnson M, Zaretskaya I, Raytselis Y, Merezhuk Y, McGinnis S, \& Madden T.L. NCBI BLAST: a better web interface, 2008. Available from: http://blast.ncbi.nlm.nih.gov/Blast.cgi [2011 Sep 5].

Macedo AM, Martins MS, Chiari E, Pena SD. DNA fingerprinting of Trypanosoma cruzi: a new tool for characterization of strains and clones. Mol Biochem Parasitol. 1992 Oct;55(12):147-53.

Machado AV, Cardoso JE, Claser C, Rodrigues MM, Gazzinelli RT, Bruna-Romero O. Longterm protective immunity induced against Trypanosoma cruzi infection after vaccination with recombinant adenoviruses encoding amastigote surface protein-2 and trans-sialidase. Hum Gene Ther. 2006 Sep;17(9):898-908.

Martin SK, Oduola AM, Milhous WK. Reversal of chloroquine resistance in Plasmodium falciparum by verapamil. Science. 1987 Feb 20;235(4791):899-901.

Masana M, de Toranzo EG, Rubio M, Castro JA. Effect of benznidazole on the mixed function oxygenase system from rat liver microsomes. Arch Int Pharmacodyn Ther. 1985 $\mathrm{Jul} ; 276(1): 4-11$.

Matovu E, Seebeck T, Enyaru JC, Kaminsky R. Drug resistance in Trypanosoma brucei spp., the causative agents of sleeping sickness in man and nagana in cattle. Microbes Infect. 2001 Jul;3(9):763-70.

Mejia AM, Triana O. Genetic variability of Trypanosoma cruzi in blood and organs of infected mice determined by LSSP-PCR. Biomedica. 2005 Mar;25(1):76-86.

Miles MA, Souza A, Povoa M, Shaw JJ, Lainson R, Toye PJ. Isozymic heterogeneity of Trypanosoma cruzi in the first autochthonous patients with Chagas' disease in Amazonian Brazil. Nature. 1978 Apr 27;272(5656):819-21.

Miles MA, Llewellyn MS, Lewis MD, Yeo M, Baleela R, Fitzpatrick S, et al. The molecular epidemiology and phylogeography of Trypanosoma cruzi and parallel research on Leishmania: looking back and to the future. Parasitology. 2009 Oct;136(12):1509-28.

Minning TA, Bua J, Garcia GA, McGraw RA, Tarleton RL. Microarray profiling of gene expression during trypomastigote to amastigote transition in Trypanosoma cruzi. Mol Biochem Parasitol. 2003 Sep;131(1):55-64.

Moncayo A. Chagas disease: current epidemiological trends after the interruption of vectorial and transfusional transmission in the Southern Cone countries. Mem Inst Oswaldo Cruz. 2003 Jul;98(5):577-91.

Morel C, Chiari E, Camargo EP, Mattei DM, Romanha AJ, Simpson L. Strains and clones of Trypanosoma cruzi can be characterized by pattern of restriction endonuclease products of kinetoplast DNA minicircles. Proc Natl Acad Sci U S A. 1980 Nov;77(11):6810-4. 
Moreno Vigo M. Microarranjos de DNA para análise da expressão gênica em cepas de Trypanosoma cruzi suscetíveis e resistentes a benznidazol. [tese (Doutorado em Biologia da Relação Patógeno-Hospedeiro)]. São Paulo: Instituto de Ciências Biomédicas da Universidade de São Paulo; 2008. Disponível em:

http://www.teses.usp.br/teses/disponiveis/42/42135/tde-31032009-104038/pt-br.php [2011 set 2].

Moreno M, D'Avila D A, Silva MN, Galvao LM, Macedo AM, Chiari E, et al. Trypanosoma cruzi benznidazole susceptibility in vitro does not predict the therapeutic outcome of human Chagas disease. Mem Inst Oswaldo Cruz. 2010 Nov;105(7):918-24.

Morisaki K, Robey RW, Ozvegy-Laczka C, Honjo Y, Polgar O, Steadman K, et al. Single nucleotide polymorphisms modify the transporter activity of ABCG2. Cancer Chemother Pharmacol. 2005 Aug;56(2):161-72.

Murta SM, Gazzinelli RT, Brener Z, Romanha AJ. Molecular characterization of susceptible and naturally resistant strains of Trypanosoma cruzi to benznidazole and nifurtimox. Mol Biochem Parasitol. 1998 Jun 1;93(2):203-14.

Murta SM, Krieger MA, Montenegro LR, Campos FF, Probst CM, Avila AR, et al. Deletion of copies of the gene encoding old yellow enzyme (TcOYE), a NAD(P)H flavin oxidoreductase, associates with in vitro-induced benznidazole resistance in Trypanosoma cruzi. Mol Biochem Parasitol. 2006 Apr;146(2):151-62.

Nogueira FB, Krieger MA, Nirde P, Goldenberg S, Romanha AJ, Murta SM. Increased expression of iron-containing superoxide dismutase-A (TcFeSOD-A) enzyme in Trypanosoma cruzi population with in vitro-induced resistance to benznidazole. Acta Trop. 2006 Nov;100(1-2):119-32.

Nogueira Silva JJ, Pavanelli WR, Gutierrez FR, Alves Lima FC, Ferreira da Silva AB, Santana Silva J, et al. Complexation of the anti-Trypanosoma cruzi drug benznidazole improves solubility and efficacy. J Med Chem. 2008 Jul 24;51(14):4104-14.

Page RD. TreeView: an application to display phylogenetic trees on personal computers. Comput Appl Biosci. 1996 Aug;12(4):357-8.

Pinazo MJ, Canas E, Elizalde JI, Garcia M, Gascon J, Gimeno F, et al. Diagnosis, management and treatment of chronic Chagas' gastrointestinal disease in areas where Trypanosoma cruzi infection is not endemic. Gastroenterol Hepatol. 2010 Mar;33(3):191-200.

Preziosi P. Science, pharmacoeconomics and ethics in drug R\&D: a sustainable future scenario? Nat Rev Drug Discov. 2004 Jun;3(6):521-6.

Ouellette M, Fase-Fowler F, Borst P. The amplified H circle of methotrexate-resistant Leishmania tarentolae contains a novel P-glycoprotein gene. EMBO J. 1990 Apr;9(4):102733.

Ouellette M, Legare D, Haimeur A, Grondin K, Roy G, Brochu C, et al. ABC transporters in Leishmania and their role in drug resistance. Drug Resist Updat. 1998 Mar;1(1):43-8. 
Papadopoulou B, Roy G, Ouellette M. A novel antifolate resistance gene on the amplified H circle of Leishmania. EMBO J. 1992 Oct;11(10):3601-8.

Pfaffl MW. A new mathematical model for relative quantification in real-time RT-PCR. Nucleic Acids Res. 2001 May 1;29(9):e45.

Pronker ES, Weenen TC, Commandeur HR, Osterhaus AD, Claassen HJ. The gold industry standard for risk and cost of drug and vaccine development revisited. Vaccine. 2011. 29(35):5846-9.

Qadir M, O'Loughlin KL, Fricke SM, Williamson NA, Greco WR, Minderman H, et al. Cyclosporin A is a broad-spectrum multidrug resistance modulator. Clin Cancer Res. 2005 Mar 15;11(6):2320-6.

Raaflaub J. The bioavailability of orally administered drugs with special regard to the liver as a filter for foreign matter. Schweiz Med Wochenschr. 1980 Mar 8;110(10):354-62.

Rassi Jr. A, Rassi A, Marin-Neto JA. Chagas disease. Lancet. 2010 Apr 17;375(9723):1388402.

Robey RW, Shukla S, Finley EM, Oldham RK, Barnett D, Ambudkar SV, et al. Inhibition of P-glycoprotein (ABCB1)- and multidrug resistance-associated protein 1 (ABCC1)-mediated transport by the orally administered inhibitor, CBT-1((R)). Biochem Pharmacol. 2008 Mar 15;75(6):1302-12.

Rosenberg MF, Velarde G, Ford RC, Martin C, Berridge G, Kerr ID, et al. Repacking of the transmembrane domains of P-glycoprotein during the transport ATPase cycle. EMBO J. 2001 Oct 15;20(20):5615-25.

Ross DD, Yang W, Abruzzo LV, Dalton WS, Schneider E, Lage H, et al. Atypical multidrug resistance: breast cancer resistance protein messenger RNA expression in mitoxantroneselected cell lines. J Natl Cancer Inst. 1999 Mar 3;91(5):429-33.

Saitou N, Nei M. The neighbor-joining method: a new method for reconstructing phylogenetic trees. Mol Biol Evol. 1987 Jul;4(4):406-25.

Sambrook J, Russell DW. Molecular cloning: a laboratory manual. 3rd ed. New York: Cold Spring Harbor Laboratory Press; 2001.

Sauvage V, Aubert D, Bonhomme A, Pinon JM, Millot JM. P-glycoprotein inhibitors modulate accumulation and efflux of xenobiotics in extra and intracellular Toxoplasma gondii. Mol Biochem Parasitol. 2004 Mar;134(1):89-95.

Sauvage V, Aubert D, Escotte-Binet S, Villena I. The role of ATP-binding cassette (ABC) proteins in protozoan parasites. Mol Biochem Parasitol. 2009 Oct;167(2):81-94.

Schmunis GA. Epidemiology of Chagas disease in non-endemic countries: the role of international migration. Mem Inst Oswaldo Cruz. 2007 Oct 30;102(Suppl 1):75-85. 
Shigeta J, Katayama K, Mitsuhashi J, Noguchi K, Sugimoto Y. BCRP/ABCG2 confers anticancer drug resistance without covalent dimerization. Cancer Sci. 2010 Aug;101(8):181321.

Silber AM, Tonelli RR, Lopes CG, Cunha-e-Silva N, Torrecilhas AC, Schumacher RI, et al. Glucose uptake in the mammalian stages of Trypanosoma cruzi. Mol Biochem Parasitol. 2009 Nov;168(1):102-8.

Sosa-Estani S, Segura EL, Ruiz AM, Velazquez E, Porcel BM, Yampotis C. Efficacy of chemotherapy with benznidazole in children in the indeterminate phase of Chagas' disease. Am J Trop Med Hyg. 1998 Oct;59(4):526-9.

Sosa-Estani S, Dri L, Touris C, Abalde S, Dell'arciprete A, Braunstein J. Vectorial and congenital transmission of Trypanosoma cruzi in Las Lomitas, Formosa. Medicina (B Aires). 2009;69(4):424-30.

Scheffer GL, Maliepaard M, Pijnenborg AC, van Gastelen MA, de Jong MC, Schroeijers AB, et al. Breast cancer resistance protein is localized at the plasma membrane in mitoxantroneand topotecan-resistant cell lines. Cancer Res. 2000 May 15;60(10):2589-93.

Shahi SK, Krauth-Siegel RL, Clayton CE. Overexpression of the putative thiol conjugate transporter TbMRPA causes melarsoprol resistance in Trypanosoma brucei. Mol Microbiol. 2002 Mar;43(5):1129-38.

Souto RP, Fernandes O, Macedo AM, Campbell DA, Zingales B. DNA markers define two major phylogenetic lineages of Trypanosoma cruzi. Mol Biochem Parasitol. 1996 Dec 20;83(2):141-52.

Sturm NR, Campbell DA. Alternative lifestyles: the population structure of Trypanosoma cruzi. Acta Trop. 2010 Jul-Aug;115(1-2):35-43.

Susanto J, Lin YH, Chen YN, Shen CR, Yan YT, Tsai ST, et al. Porphyrin homeostasis maintained by ABCG2 regulates self-renewal of embryonic stem cells. PLoS One. 2008;3(12):e4023.

Swofford DL, Waddell PJ, Huelsenbeck JP, Foster PG, Lewis PO, Rogers JS. Bias in phylogenetic estimation and its relevance to the choice between parsimony and likelihood methods. Syst Biol. 2001 Aug;50(4):525-39.

Temperton NJ, Wilkinson SR, Meyer DJ, Kelly JM. Overexpression of superoxide dismutase in Trypanosoma cruzi results in increased sensitivity to the trypanocidal agents gentian violet and benznidazole. Mol Biochem Parasitol. 1998 Oct 30;96(1-2):167-76.

Tibayrenc M, Breniere SF. Trypanosoma cruzi: major clones rather than principal zymodemes. Mem Inst Oswaldo Cruz. 1988 Nov;83(Suppl 1):249-55.

Tibayrenc M. Population genetics and strain typing of microorganisms: how to detect departures from panmixia without individualizing alleles and loci. C R Acad Sci III. 1995 Jan;318(1):135-9. 
Toledo MJ, de Lana M, Carneiro CM, Bahia MT, Machado-Coelho GL, Veloso VM, et al. Impact of Trypanosoma cruzi clonal evolution on its biological properties in mice. Exp Parasitol. 2002 Mar;100(3):161-72.

Thompson JD, Higgins DG, Gibson TJ. CLUSTAL W: improving the sensitivity of progressive multiple sequence alignment through sequence weighting, position-specific gap penalties and weight matrix choice. Nucleic Acids Res. 1994 Nov 11;22(22):4673-80.

Tiwari AK, Souza RP, Muller DJ. Pharmacogenetics of anxiolytic drugs. J Neural Transm. 2009 Jun;116(6):667-77.

Torres C, Perez-Victoria FJ, Parodi-Talice A, Castanys S, Gamarro F. Characterization of an ABCA-like transporter involved in vesicular trafficking in the protozoan parasite Trypanosoma cruzi. Mol Microbiol. 2004 Nov;54(3):632-46.

Urbina JA, Payares G, Sanoja C, Molina J, Lira R, Brener Z, et al. Parasitological cure of acute and chronic experimental Chagas disease using the long-acting experimental triazole TAK-187. Activity against drug-resistant Trypanosoma cruzi strains. Int J Antimicrob Agents. 2003 Jan;21(1):39-48.

TriTrypDB, Kinetoplastid Genomics Reource from EuPathDB Genomes and Data Types, 2011. Available from: http://tritrypdb.org/tritrypdb/ [2011 Sep 5].

Urbina JA, Docampo R. Specific chemotherapy of Chagas disease: controversies and advances. Trends Parasitol. 2003 Nov;19(11):495-501.

Urbina JA. Ergosterol biosynthesis and drug development for Chagas disease. Mem Inst Oswaldo Cruz. 2009 Jul;104(Suppl 1):311-8.

Urbina JA. Specific chemotherapy of Chagas disease: relevance, current limitations and new approaches. Acta Trop. 2010 Jul-Aug;115(1-2):55-68.

Viotti R, Vigliano C, Armenti A. A risk score for predicting death in Chagas' heart disease. N Engl J Med. 2006 Dec 7;355(23):2489.

Wagner-Souza K, Echevarria-Lima J, Rodrigues LA, Reis M, Rumjanek VM. Resistance to thapsigargin-induced intracellular calcium mobilization in a multidrug resistant tumour cell line. Mol Cell Biochem. 2003 Oct;252(1-2):109-16.

Walker JE, Saraste M, Runswick MJ, Gay NJ. Distantly related sequences in the alpha- and beta-subunits of ATP synthase, myosin, kinases and other ATP-requiring enzymes and a common nucleotide binding fold. EMBO J. 1982;1(8):945-51.

Wang Y, Addess KJ, Chen J, Geer LY, He J, He S, Lu S, Madej T, Marchler-Bauer A, Thiessen PA, Zhang N, Bryant SH. MMDB: annotating protein sequences with Entrez's 3Dstructure database, 2007. Available from: http://www.ncbi.nlm.nih.gov/Structure/ [2011 Sep 5].

Weatherly DB, Boehlke C, Tarleton RL. Chromosome level assembly of the hybrid Trypanosoma cruzi genome. BMC Genomics. 2009; 10:255. 
Wilkinson SR, Taylor MC, Horn D, Kelly JM, Cheeseman I. A mechanism for crossresistance to nifurtimox and benznidazole in trypanosomes. Proc Natl Acad Sci U S A. 2008 Apr 1;105(13):5022-7.

Wilson CM, Serrano AE, Wasley A, Bogenschutz MP, Shankar AH, Wirth DF. Amplification of a gene related to mammalian mdr genes in drug-resistant Plasmodium falciparum. Science. 1989 Jun 9;244(4909):1184-6.

Workman EM, Alun Jones V, Wilson AJ, Hunter JO. Diet in the management of Crohn's disease. Hum Nutr Appl Nutr. 1984 Dec;38(6):469-73.

Yanase K, Tsukahara S, Mitsuhashi J, Sugimoto Y. Functional SNPs of the breast cancer resistance protein-therapeutic effects and inhibitor development. Cancer Lett. 2006 Mar 8;234(1):73-80.

Yun O, Lima MA, Ellman T, Chambi W, Castillo S, Flevaud L, et al. Feasibility, drug safety, and effectiveness of etiological treatment programs for Chagas disease in Honduras, Guatemala, and Bolivia: 10-year experience of Medecins Sans Frontieres. PLoS Negl Trop Dis. 2009;3(7):e488.

Xie Y, Xu K, Linn DE, Yang X, Guo Z, Shimelis H, et al. The 44-kDa Pim-1 kinase phosphorylates BCRP/ABCG2 and thereby promotes its multimerization and drug-resistant activity in human prostate cancer cells. J Biol Chem. 2008 Feb 8;283(6):3349-56.

Zingales B, Stolf BS, Souto RP, Fernandes O, Briones MR. Epidemiology, biochemistry and evolution of Trypanosoma cruzi lineages based on ribosomal RNA sequences. Mem Inst Oswaldo Cruz. 1999;94(Suppl 1):159-64.

Zingales B, Andrade SG, Briones MR, Campbell DA, Chiari E, Fernandes O, et al. A new consensus for Trypanosoma cruzi intraspecific nomenclature: second revision meeting recommends TcI to TcVI. Mem Inst Oswaldo Cruz. 2009 Nov;104(7):1051-4. 


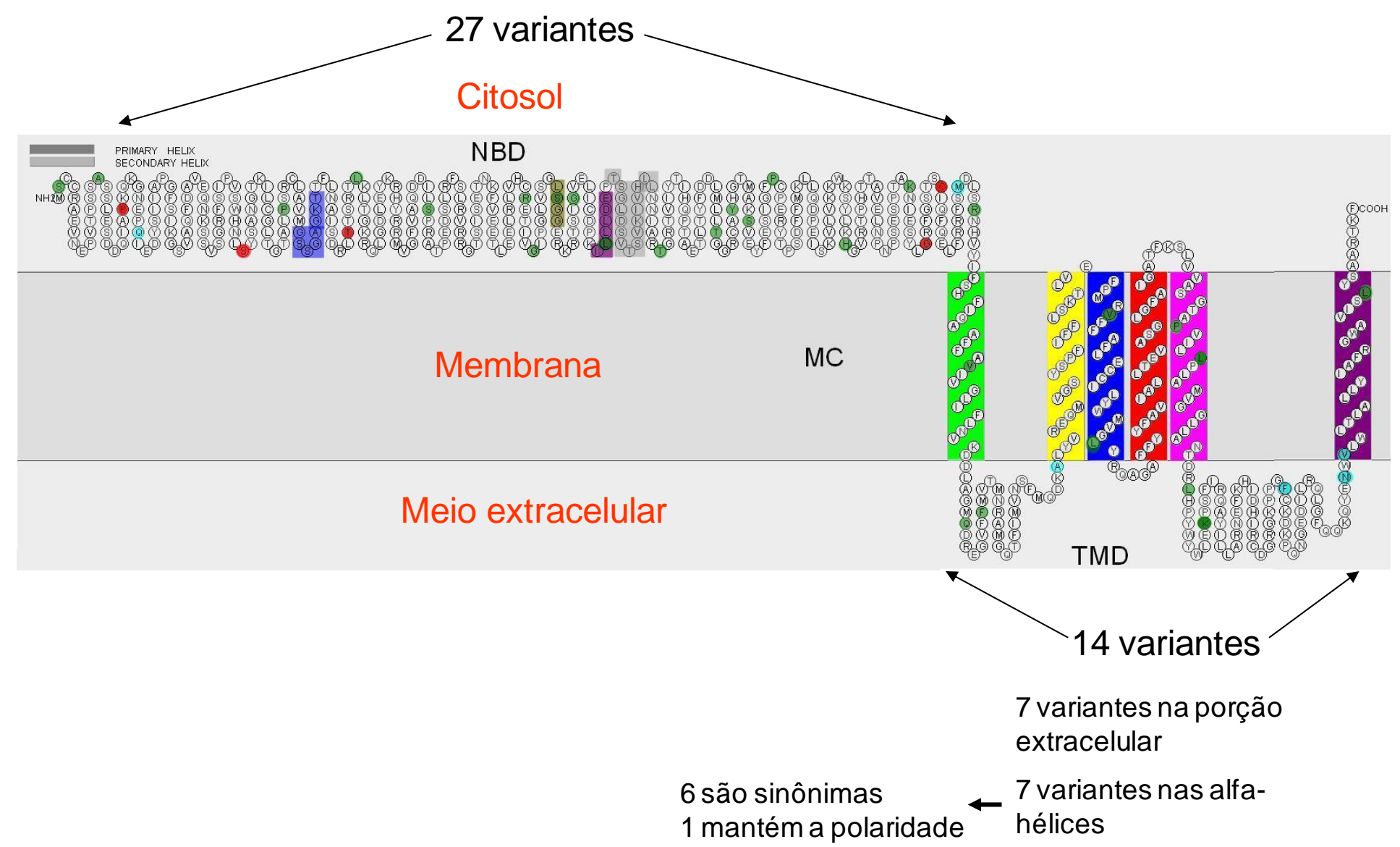

Figura A.1 - Estrutura secundária da proteína TcABCG1 do haplótipo Não-Esmo de CL Brener. A proteína tem 665 aminoácidos e apresenta 41 variantes em relação à proteína TcABCG1 do haplótipo Esmo de CL Brener. Dentre as 41 variações de aminoácidos: 28 originam o mesmo aminoácido (mutações sinônimas); 6 promovem alteração do aminoácido, mas manutenção de sua polaridade; 7 promovem alteração do aminoácido e de sua polaridade (neste caso, em 6 variantes há mudanças de apolar para polar neutro e vice-versa). 

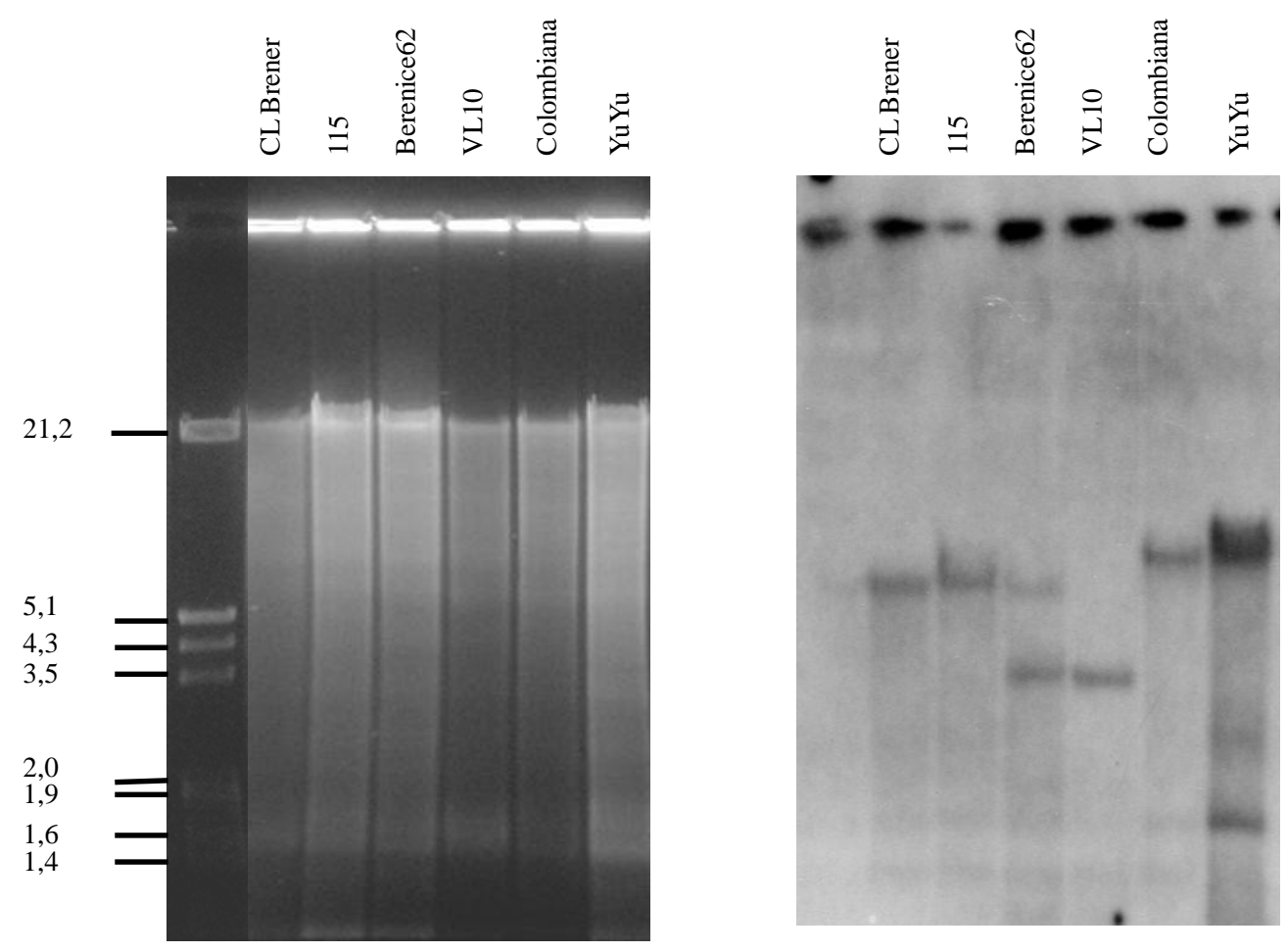

Figura A.2 - Southern Blotting de DNA genômico de seis cepas de T. cruzi digerido com HindIII e hibridizado com a sonda $T c A B C G 1$ de $616 \mathrm{pb}$ marcada com $\mathrm{P}^{32}$. O primeiro painel mostra o padrão de coloração do DNA com brometo de etídio, e o segundo mostra o sinal de hibridização da membrana após exposição de 24 horas em Phosphor Image. À esquerda do primeiro painel indica-se o tamanho molecular em kb. 
Tabela A.1 - Genes de transportadores ABC de T. cruzi alelos e ortólogos a espécies de Leishmania e tripanossomas africanos.

(continua)

\begin{tabular}{|c|c|c|c|c|c|c|c|c|c|c|}
\hline Código do gene & $\begin{array}{l}\text { Subfa } \\
\text { mília }\end{array}$ & Alelo $T$. cruzi & $\begin{array}{l}\text { Ortólogo } L . \\
\text { braziliense }\end{array}$ & $\begin{array}{l}\text { Ortólogo } L . \\
\text { infantum }\end{array}$ & $\begin{array}{l}\text { Ortólogo L. } \\
\text { major }\end{array}$ & $\begin{array}{l}\text { Ortólogo } L \text {. } \\
\text { mexicana }\end{array}$ & $\begin{array}{l}\text { Ortólogo } T . \\
\text { brucei }\end{array}$ & $\begin{array}{l}\text { Ortólogo } T . \\
\text { gambiense }\end{array}$ & $\begin{array}{l}\text { Ortólogo } T . \\
\text { congolense }\end{array}$ & $\begin{array}{l}\text { Ortólogo } \\
T \text {. vivax }\end{array}$ \\
\hline $\begin{array}{l}\text { Tc00.104705351 } \\
0149.80\end{array}$ & A & $\begin{array}{l}\text { Tc00.104705350 } \\
6989.30\end{array}$ & $\begin{array}{l}\text { LbrM29_V2.06 } \\
30\end{array}$ & $\begin{array}{l}\text { LinJ29_V3.06 } \\
40\end{array}$ & $\begin{array}{l}\mathrm{LmjF} 29.062 \\
0\end{array}$ & $\begin{array}{l}\text { LmxM08_29.0 } \\
620\end{array}$ & $\begin{array}{l}\mathrm{Tb} 927.3 .373 \\
0\end{array}$ & Tbg972.3.4040 & $\begin{array}{l}\text { TcIL3000.3.24 } \\
20\end{array}$ & não tem \\
\hline $\begin{array}{l}\text { Tc00.104705350 } \\
6989.30\end{array}$ & A & $\begin{array}{l}\text { Tc00.104705351 } \\
0149.80\end{array}$ & $\begin{array}{l}\text { LbrM29_V2.06 } \\
30\end{array}$ & $\begin{array}{l}\text { LinJ29_V3.06 } \\
40\end{array}$ & $\begin{array}{l}\text { LmjF29.062 } \\
0\end{array}$ & $\begin{array}{l}\text { LmxM08_29.0 } \\
620\end{array}$ & $\begin{array}{l}\text { Tb927.3.373 } \\
0\end{array}$ & Tbg972.3.4040 & $\begin{array}{l}\text { TcIL3000.3.24 } \\
20\end{array}$ & não tem \\
\hline $\begin{array}{l}\text { Tc00.104705350 } \\
4881.50\end{array}$ & A & $\begin{array}{l}\text { Tc00.104705351 } \\
0045.20\end{array}$ & $\begin{array}{l}\text { LbrM15_V2.08 } \\
20\end{array}$ & $\begin{array}{l}\text { LinJ15_V3.08 } \\
00\end{array}$ & $\begin{array}{l}\text { LmjF15.076 } \\
0\end{array}$ & LmxM15.0760 & não tem & não tem & não tem & não tem \\
\hline $\begin{array}{l}\text { Tc00.104705351 } \\
0045.20\end{array}$ & A & $\begin{array}{l}\text { Tc00.104705350 } \\
4881.50\end{array}$ & $\begin{array}{l}\text { LbrM15_V2.08 } \\
20\end{array}$ & $\begin{array}{l}\text { LinJ15_V3.08 } \\
00\end{array}$ & $\begin{array}{l}\text { LmjF15.076 } \\
0\end{array}$ & LmxM15.0760 & não tem & não tem & não tem & não tem \\
\hline $\begin{array}{l}\text { Tc00.104705350 } \\
3573.9\end{array}$ & A & $\begin{array}{l}\text { Tc00.104705350 } \\
4149.20\end{array}$ & $\begin{array}{l}\text { LbrM11_V2.10 } \\
00\end{array}$ & $\begin{array}{l}\text { LinJ11_V3.12 } \\
10\end{array}$ & $\begin{array}{l}\text { LmjF11.122 } \\
0\end{array}$ & LmxM11.1240 & $\begin{array}{l}\text { Tb11.02.395 } \\
0\end{array}$ & $\begin{array}{l}\text { Tbg972.11.688 } \\
0\end{array}$ & $\begin{array}{l}\text { TcIL3000.11.6 } \\
660\end{array}$ & não tem \\
\hline $\begin{array}{l}\text { Tc00.104705350 } \\
4149.20\end{array}$ & A & $\begin{array}{l}\text { Tc00.104705350 } \\
3573.9\end{array}$ & $\begin{array}{l}\text { LbrM11_V2.10 } \\
00\end{array}$ & $\begin{array}{l}\text { LinJ11_V3.12 } \\
10\end{array}$ & $\begin{array}{l}\text { LmjF11.122 } \\
0\end{array}$ & LmxM11.1240 & $\begin{array}{l}\text { Tb11.02.395 } \\
0\end{array}$ & $\begin{array}{l}\text { Tbg972.11.688 } \\
0\end{array}$ & $\begin{array}{l}\text { TcIL3000.11.6 } \\
660\end{array}$ & não tem \\
\hline $\begin{array}{l}\text { Tc00.104705350 } \\
7099.80\end{array}$ & A & não tem & não tem & não tem & não tem & não tem & não tem & não tem & não tem & não tem \\
\hline $\begin{array}{l}\text { Tc00.104705351 } \\
1725.80\end{array}$ & A & não tem & não tem & não tem & não tem & não tem & não tem & não tem & não tem & não tem \\
\hline $\begin{array}{l}\text { Тc00.104705350 } \\
3749.60\end{array}$ & $\mathrm{~B}$ & não tem & não tem & não tem & não tem & não tem & não tem & não tem & não tem & não tem \\
\hline $\begin{array}{l}\text { Tc00.104705351 } \\
1021.70\end{array}$ & B & não tem & $\begin{array}{l}\text { LbrM32_V2.33 } \\
80\end{array}$ & $\begin{array}{l}\text { LinJ32_V3.32 } \\
80\end{array}$ & $\begin{array}{l}\text { LmjF32.308 } \\
0\end{array}$ & LmxM31.3080 & $\begin{array}{l}\text { Tb11.01.870 } \\
0\end{array}$ & $\begin{array}{l}\text { Tbg972.11.191 } \\
10\end{array}$ & $\begin{array}{l}\text { TcIL3000.11.1 } \\
6840\end{array}$ & $\begin{array}{l}\text { TvY486_1 } \\
117940\end{array}$ \\
\hline $\begin{array}{l}\text { Tc00.104705351 } \\
1537.8\end{array}$ & B & não tem & não tem & não tem & não tem & não tem & não tem & não tem & não tem & não tem \\
\hline $\begin{array}{l}\text { Tc00.104705350 } \\
7093.260\end{array}$ & $\mathrm{~B}$ & não tem & $\begin{array}{l}\text { LbrM25_V2.04 } \\
80\end{array}$ & $\begin{array}{l}\text { LinJ25_V3.05 } \\
40\end{array}$ & $\begin{array}{l}\text { LmjF25.053 } \\
0\end{array}$ & LmxM25.0530 & $\begin{array}{l}\text { Tb11.03.054 } \\
0\end{array}$ & Tbg972.11.510 & $\begin{array}{l}\text { TcIL3000.11.5 } \\
00\end{array}$ & $\begin{array}{l}\text { TvY486_1 } \\
100360\end{array}$ \\
\hline $\begin{array}{l}\text { Tc00.104705351 } \\
0885.70\end{array}$ & B & $\begin{array}{l}\text { Tc00.104705350 } \\
6529.160\end{array}$ & $\begin{array}{l}\text { LbrM12_V2.08 } \\
70\end{array}$ & $\begin{array}{l}\text { LinJ12_V3.07 } \\
90\end{array}$ & $\begin{array}{l}\text { LmjF12.119 } \\
0\end{array}$ & LmxM12.1190 & $\begin{array}{l}\text { Tb927.1.442 } \\
0\end{array}$ & Tbg972.1.2960 & $\begin{array}{l}\text { TcIL3000.0.30 } \\
940\end{array}$ & $\begin{array}{l}\text { TvY486_0 } \\
101960\end{array}$ \\
\hline $\begin{array}{l}\text { Tc00.104705350 } \\
6529.160\end{array}$ & $\mathrm{~B}$ & $\begin{array}{l}\text { Tc00.104705351 } \\
0885.70\end{array}$ & $\begin{array}{l}\text { LbrM12_V2.08 } \\
70\end{array}$ & $\begin{array}{l}\text { LinJ12_V3.07 } \\
90\end{array}$ & $\begin{array}{l}\text { LmjF12.119 } \\
0\end{array}$ & LmxM12.1190 & $\begin{array}{l}\text { Tb927.1.442 } \\
0\end{array}$ & Tbg972.1.2960 & $\begin{array}{l}\text { TcIL3000.0.30 } \\
940\end{array}$ & $\begin{array}{l}\text { TvY486_0 } \\
101960\end{array}$ \\
\hline $\begin{array}{l}\text { Tc00.104705351 } \\
0785.10\end{array}$ & B & não tem & não tem & não tem & não tem & não tem & não tem & não tem & não tem & não tem \\
\hline $\begin{array}{l}\text { Тc00.104705350 } \\
6619.90\end{array}$ & B & $\begin{array}{l}\text { Tc00.104705350 } \\
8809.30\end{array}$ & $\begin{array}{l}\text { LbrM33_V2.33 } \\
20\end{array}$ & $\begin{array}{l}\text { LinJ33_V3.32 } \\
00\end{array}$ & $\begin{array}{l}\text { LmjF33.304 } \\
0\end{array}$ & LmxM32.3040 & $\begin{array}{l}\text { Tb927.2.541 } \\
0\end{array}$ & $\begin{array}{l}\text { Tbg.972.2.382 } \\
0\end{array}$ & $\begin{array}{l}\text { TcIL3000.2.14 } \\
40\end{array}$ & $\begin{array}{l}\text { TvY486_0 } \\
201750\end{array}$ \\
\hline
\end{tabular}


Tabela A.1 - Genes de transportadores ABC de T. cruzi alelos e ortólogos a espécies de Leishmania e tripanossomas africanos.

(continuação)

\begin{tabular}{|c|c|c|c|c|c|c|c|c|c|c|}
\hline Código do gene & $\begin{array}{l}\text { Subfa } \\
\text { mília }\end{array}$ & Alelo $T$. cruzi & $\begin{array}{l}\text { Ortólogo } L . \\
\text { braziliense }\end{array}$ & $\begin{array}{l}\text { Ortólogo } L . \\
\text { infantum }\end{array}$ & $\begin{array}{l}\text { Ortólogo L. } \\
\text { major }\end{array}$ & $\begin{array}{l}\text { Ortólogo } L \text {. } \\
\text { mexicana }\end{array}$ & $\begin{array}{l}\text { Ortólogo } T . \\
\text { brucei }\end{array}$ & $\begin{array}{l}\text { Ortólogo } T . \\
\text { gambiense }\end{array}$ & $\begin{array}{l}\text { Ortólogo } T . \\
\text { congolense }\end{array}$ & $\begin{array}{l}\text { Ortólogo } \\
T . \text { vivax } \\
\end{array}$ \\
\hline Tc00.104705350 & & Tc00.104705350 & LbrM33_V2.3 & LinJ33_V3.32 & LmjF33.304 & LmxM32.304 & Tb927.2.54 & Tbg.972.2.382 & TcIL3000.2.14 & TvY486_0 \\
\hline 8809.30 & B & 6619.90 & 320 & 00 & 0 & 0 & 10 & 0 & 40 & 201750 \\
\hline Tc00.104705350 & & Tc00.104705350 & LbrM33_V2.3 & LinJ33_V3.34 & LmjF33.326 & LmxM32.326 & $\mathrm{Tb} 927.2 .61$ & Tbg.972.2.428 & & \\
\hline 6817.20 & B & 7105.70 & 540 & $10-$ & 0 & 0 & 30 & 0 & năo tem & năo tem \\
\hline Tc00.104705350 & & Tc00.104705350 & LbrM33_V2.3 & LinJ33_V3.34 & LmjF33.326 & LmxM32.326 & $\mathrm{Tb} 927.2 .61$ & Tbg.972.2.428 & & \\
\hline 7105.70 & B & 6817.20 & 540 & $10-$ & 0 & 0 & 30 & 0 & nao tem & nao tem \\
\hline $\begin{array}{l}\text { Tc00.104705350 } \\
9007.99\end{array}$ & B & $\begin{array}{l}\text { Tc00.104705351 } \\
1385.120\end{array}$ & não tem & não tem & não tem & não tem & não tem & não tem & não tem & não tem \\
\hline $\begin{array}{l}\text { Tc00.104705351 } \\
1385.120\end{array}$ & B & $\begin{array}{l}\text { Tc00.104705350 } \\
9007.99\end{array}$ & não tem & não tem & não tem & não tem & não tem & não tem & não tem & não tem \\
\hline $\begin{array}{l}\text { Tc00.104705351 } \\
0231.29\end{array}$ & $\mathrm{C}$ & $\begin{array}{l}\text { Tc00.104705350 } \\
6559.100\end{array}$ & não tem & não tem & não tem & não tem & $\begin{array}{l}\text { Tb927.4.25 } \\
10\end{array}$ & Tbg972.4.2470 & $\begin{array}{l}\text { TcIL3000.0.08 } \\
390\end{array}$ & $\begin{array}{l}\text { TvY486_0 } \\
402420\end{array}$ \\
\hline $\begin{array}{l}\text { Tc00.104705350 } \\
6559.100\end{array}$ & $\mathrm{C}$ & $\begin{array}{l}\text { Tc00.104705351 } \\
0231.29\end{array}$ & não tem & não tem & não tem & não tem & $\begin{array}{l}\text { Tb927.4.25 } \\
10\end{array}$ & Tbg972.4.2470 & $\begin{array}{l}\text { TcIL3000.0.08 } \\
390\end{array}$ & $\begin{array}{l}\text { TvY486_0 } \\
402420\end{array}$ \\
\hline $\begin{array}{l}\text { Tc00.104705344 } \\
7255.29\end{array}$ & $\mathrm{C}$ & não tem & não tem & não tem & não tem & não tem & não tem & não tem & não tem & não tem \\
\hline $\begin{array}{l}\text { Tc00.104705350 } \\
8965.14\end{array}$ & $\mathrm{C}$ & não tem & $\begin{array}{l}\text { LbrM31_V2.1 } \\
500\end{array}$ & $\begin{array}{l}\text { LinJ31_V3.13 } \\
00\end{array}$ & $\begin{array}{l}\text { LmjF31.128 } \\
0\end{array}$ & $\begin{array}{l}\operatorname{LmxM} 30.127 \\
0\end{array}$ & $\begin{array}{l}\text { Tb927.4.44 } \\
90\end{array}$ & Tbg972.4.4600 & não tem & $\begin{array}{l}\text { TvY486_0 } \\
403980\end{array}$ \\
\hline $\begin{array}{l}\text { Tc00.104705350 } \\
7079.30\end{array}$ & $\mathrm{C}$ & não tem & não tem & não tem & não tem & não tem & não tem & não tem & não tem & não tem \\
\hline $\begin{array}{l}\text { Tc00.104705345 } \\
7101.30\end{array}$ & $\mathrm{C}$ & não tem & não tem & não tem & não tem & não tem & não tem & não tem & não tem & não tem \\
\hline $\begin{array}{l}\text { Tc00.104705350 } \\
6417.83\end{array}$ & $\mathrm{C}$ & não tem & não tem & não tem & não tem & não tem & não tem & não tem & não tem & não tem \\
\hline $\begin{array}{l}\text { Tc00.104705350 } \\
6417.10\end{array}$ & $\mathrm{C}$ & não tem & $\begin{array}{l}\text { LbrM23_V2.0 } \\
230\end{array}$ & $\begin{array}{l}\text { LinJ23_V3.02 } \\
30\end{array}$ & $\begin{array}{l}\text { LmjF23.021 } \\
0\end{array}$ & $\begin{array}{l}\text { LmxM23.021 } \\
0\end{array}$ & $\begin{array}{l}\text { Tb927.8.21 } \\
60\end{array}$ & não tem & não tem & não tem \\
\hline Tc00.104705351 & $\mathrm{D}$ & & LbrM33_V2.2 & LinJ33_V3.19 & LmjF33.186 & LmxM32.186 & Tb11.02.06 & Tbg972.11.346 & TcIL3000.11.2 & TvY486_1 \\
\hline 0431.150 & D & nao tem & 130 & 60 & 0 & 0 & 30 & 0 & 910 & $103170^{-}$ \\
\hline Tc00.104705350 & $\mathrm{D}$ & não tem & LbrM27_V2.0 & LinJ27_V3.04 & LmjF27.047 & LmxM27.047 & Tb11.03.00 & Tbg972.11.115 & TcIL3000.11.1 & TvY486_1 \\
\hline 6925.530 & $D$ & nas tem & 580 & 80 & 0 & 0 & 30 & 0 & 020 & 100960 \\
\hline $\begin{array}{l}\text { Tc00.104705350 } \\
8927.20\end{array}$ & $\mathrm{D}$ & $\begin{array}{l}\text { Tc00.104705350 } \\
9237.30\end{array}$ & $\begin{array}{l}\text { LbrM31_V2.0 } \\
700\end{array}$ & $\begin{array}{l}\text { LinJ31_V3.05 } \\
60\end{array}$ & $\begin{array}{l}\text { LmjF31.054 } \\
0\end{array}$ & $\begin{array}{l}\operatorname{LmxM} 30.054 \\
0\end{array}$ & $\begin{array}{l}\text { Tb927.4.40 } \\
50\end{array}$ & Tbg972.4.4160 & $\begin{array}{l}\text { TcIL3000.10.1 } \\
3930\end{array}$ & não tem \\
\hline
\end{tabular}


Tabela A.1 - Genes de transportadores ABC de T. cruzi alelos e ortólogos a espécies de Leishmania e tripanossomas africanos.

\begin{tabular}{|c|c|c|c|c|c|c|c|c|c|c|}
\hline $\begin{array}{l}\text { Código do } \\
\text { gene }\end{array}$ & $\begin{array}{l}\text { Subfam } \\
\text { ília }\end{array}$ & Alelo $T$. cruzi & $\begin{array}{l}\text { Ortólogo } L . \\
\text { braziliense }\end{array}$ & $\begin{array}{l}\text { Ortólogo } L . \\
\text { infantum }\end{array}$ & $\begin{array}{l}\text { Ortólogo L. } \\
\text { major }\end{array}$ & $\begin{array}{l}\text { Ortólogo } L \text {. } \\
\text { mexicana }\end{array}$ & $\begin{array}{l}\text { Ortólogo } T . \\
\text { brucei }\end{array}$ & $\begin{array}{l}\text { Ortólogo } T \text {. } \\
\text { gambiense }\end{array}$ & $\begin{array}{l}\text { Ortólogo } T \text {. } \\
\text { congolense }\end{array}$ & $\begin{array}{l}\text { Ortólogo } \\
T \text {. vivax } \\
\end{array}$ \\
\hline $\begin{array}{l}\text { Tc00.10470535 } \\
09237.30\end{array}$ & $\mathrm{D}$ & $\begin{array}{l}\text { Tc00.1047053 } \\
508927.20\end{array}$ & $\begin{array}{l}\text { LbrM31_V2.07 } \\
00\end{array}$ & $\begin{array}{l}\text { LinJ31_V3.0 } \\
560\end{array}$ & LmjF31.0540 & $\begin{array}{l}\text { LmxM30.054 } \\
0\end{array}$ & $\begin{array}{l}\text { Tb927.4.40 } \\
50\end{array}$ & Tbg972.4.4160 & $\begin{array}{l}\text { TcIL3000.10.1 } \\
3930\end{array}$ & não tem \\
\hline $\begin{array}{l}\text { Tc00.10470534 } \\
64879.9\end{array}$ & $\mathrm{E}$ & não tem & $\begin{array}{l}\text { LbrM21_V2.07 } \\
70\end{array}$ & $\begin{array}{l}\text { LinJ21_V3.0 } \\
770\end{array}$ & LmjF21.0710 & $\begin{array}{l}\text { LmxM21.071 } \\
0\end{array}$ & $\begin{array}{l}\text { Tb927.10.1 } \\
630\end{array}$ & $\begin{array}{l}\text { Tbg972.10.192 } \\
0\end{array}$ & $\begin{array}{l}\text { TcIL3000.10.1 } \\
400\end{array}$ & $\begin{array}{l}\text { TvY486_1 } \\
001650\end{array}$ \\
\hline $\begin{array}{l}\text { Tc00.10470535 } \\
08637.150\end{array}$ & $\mathrm{E}$ & não tem & $\begin{array}{l}\text { LbrM21_V2.07 } \\
70\end{array}$ & $\begin{array}{l}\text { LinJ21_V3.0 } \\
770\end{array}$ & LmjF21.0710 & $\begin{array}{l}\text { LmxM21.071 } \\
0\end{array}$ & $\begin{array}{l}\text { Tb927.10.1 } \\
630\end{array}$ & $\begin{array}{l}\text { Tbg972.10.192 } \\
0\end{array}$ & $\begin{array}{l}\text { TcIL3000.10.1 } \\
400\end{array}$ & $\begin{array}{l}\text { TvY486_1 } \\
001650\end{array}$ \\
\hline $\begin{array}{l}\text { Tc00.10470535 } \\
11913.9\end{array}$ & $\mathrm{E}$ & não tem & $\begin{array}{l}\text { LbrM21_V2.07 } \\
70\end{array}$ & $\begin{array}{l}\text { LinJ21_V3.0 } \\
770\end{array}$ & LmjF21.0710 & $\begin{array}{l}\text { LmxM21.071 } \\
0\end{array}$ & $\begin{array}{l}\text { Tb927.10.1 } \\
630\end{array}$ & $\begin{array}{l}\text { Tbg972.10.192 } \\
0\end{array}$ & $\begin{array}{l}\text { TcIL3000.10.1 } \\
400\end{array}$ & $\begin{array}{l}\text { TvY486_1 } \\
001650\end{array}$ \\
\hline $\begin{array}{l}\text { Tc00.10470535 } \\
04867.20\end{array}$ & $\mathrm{~F}$ & $\begin{array}{l}\text { Tc00.1047053 } \\
510943.80\end{array}$ & $\begin{array}{l}\text { LbrM03_V2.01 } \\
70\end{array}$ & $\begin{array}{l}\text { LinJ03_V3.0 } \\
150\end{array}$ & LmjF03.0160 & $\begin{array}{l}\text { LmxM03.016 } \\
0\end{array}$ & $\begin{array}{l}\text { Tb927.10.3 } \\
170\end{array}$ & $\begin{array}{l}\text { Tbg972.10.401 } \\
0\end{array}$ & $\begin{array}{l}\text { TcIL3000.10.2 } \\
630\end{array}$ & $\begin{array}{l}486 \_1 \\
60\end{array}$ \\
\hline $\begin{array}{l}\text { Tc00.10470535 } \\
10943.80\end{array}$ & $\mathrm{~F}$ & $\begin{array}{l}\text { Tc00.1047053 } \\
504867.20\end{array}$ & $\begin{array}{l}\text { LbrM03_V2.01 } \\
70\end{array}$ & $\begin{array}{l}\text { LinJ03_V3.0 } \\
150\end{array}$ & LmjF03.0160 & $\begin{array}{l}\text { LmxM03.016 } \\
0\end{array}$ & $\begin{array}{l}\text { Tb927.10.3 } \\
170\end{array}$ & $\begin{array}{l}\text { Tbg972.10.401 } \\
0\end{array}$ & $\begin{array}{l}\text { TcIL3000.10.2 } \\
630\end{array}$ & $\begin{array}{l}\text { TvY486_1 } \\
003160\end{array}$ \\
\hline $\begin{array}{l}\text { Tc00.10470535 } \\
08897.30\end{array}$ & $\mathrm{~F}$ & não tem & $\begin{array}{l}\text { LbrM19_V2.11 } \\
10\end{array}$ & $\begin{array}{l}\text { LinJ19_V3.0 } \\
800\end{array}$ & LmjF19.0800 & $\begin{array}{l}\text { LmxM19.080 } \\
0\end{array}$ & $\begin{array}{l}\text { Tb927.10.1 } \\
5530\end{array}$ & $\begin{array}{l}\text { Tbg972.10.189 } \\
70\end{array}$ & $\begin{array}{l}\text { TcIL3000.10.1 } \\
3320\end{array}$ & $\begin{array}{l}\text { TvY486_1 } \\
014910\end{array}$ \\
\hline $\begin{array}{l}\text { Tc00.10470535 } \\
09105.130\end{array}$ & $\mathrm{~F}$ & não tem & $\begin{array}{l}\text { LbrM33_V2.03 } \\
20\end{array}$ & $\begin{array}{l}\text { LinJ33_V3.0 } \\
340\end{array}$ & LmjF33.0310 & $\begin{array}{l}\text { LmxM32.031 } \\
0\end{array}$ & $\begin{array}{l}\text { Tb927.10.1 } \\
0880\end{array}$ & $\begin{array}{l}\text { Tbg972.10.132 } \\
40\end{array}$ & $\begin{array}{l}\text { TcIL3000.10.9 } \\
180\end{array}$ & $\begin{array}{l}\text { TvY486_0 } \\
043400\end{array}$ \\
\hline $\begin{array}{l}\text { Tc00.10470535 } \\
06249.70\end{array}$ & $\mathrm{G}$ & $\begin{array}{l}\text { Tc00.1047053 } \\
508231.190\end{array}$ & não tem & não tem & não tem & não tem & $\begin{array}{l}\text { Tb927.10.7 } \\
700\end{array}$ & $\begin{array}{l}\text { Tbg972.10.944 } \\
0\end{array}$ & $\begin{array}{l}\text { TcIL3000.10.6 } \\
590\end{array}$ & $\begin{array}{l}\text { TvY486_1 } \\
007540\end{array}$ \\
\hline $\begin{array}{l}\text { Tc00.10470535 } \\
08231.190\end{array}$ & G & $\begin{array}{l}\text { Tc00.1047053 } \\
506249.70\end{array}$ & não tem & não & não tem & não & $\begin{array}{l}\text { Tb927.10.7 } \\
700\end{array}$ & $\begin{array}{l}\text { Tbg972.10.944 } \\
0\end{array}$ & $\begin{array}{l}\text { TcIL3000.10.6 } \\
590\end{array}$ & $\begin{array}{l}486 \_1 \\
40\end{array}$ \\
\hline $\begin{array}{l}\text { Tc00.10470535 } \\
06579.10\end{array}$ & $\mathrm{G}$ & $\begin{array}{l}\text { Tc00.1047053 } \\
507241.39\end{array}$ & $\begin{array}{l}\text { LbrM15_V2.09 } \\
30\end{array}$ & $\begin{array}{l}\text { LinJ15_V3.0 } \\
950\end{array}$ & LmjF15.0890 & $\begin{array}{l}\text { LmxM15.089 } \\
0\end{array}$ & $\begin{array}{l}\text { Tb09.160.4 } \\
600\end{array}$ & Tbg972.9.3310 & $\begin{array}{l}\text { TcIL3000.9.21 } \\
60\end{array}$ & $\begin{array}{l}\text { TvY486_0 } \\
902340\end{array}$ \\
\hline $\begin{array}{l}\text { Tc00.10470535 } \\
07241.39\end{array}$ & $\mathrm{G}$ & $\begin{array}{l}\text { Tc00.1047053 } \\
506579.10\end{array}$ & $\begin{array}{l}\text { LbrM15_V2.09 } \\
30\end{array}$ & $\begin{array}{l}\text { LinJ15_V3.0 } \\
950\end{array}$ & LmjF15.0890 & $\begin{array}{l}\text { LmxM15.089 } \\
0\end{array}$ & $\begin{array}{l}\text { Tb09.160.4 } \\
600\end{array}$ & Tbg972.9.3310 & $\begin{array}{l}\text { TcIL3000.9.21 } \\
60\end{array}$ & $\begin{array}{l}\text { TvY486_0 } \\
902340\end{array}$ \\
\hline $\begin{array}{l}\text { Tc00.10470535 } \\
06457.149\end{array}$ & $\mathrm{G}$ & $\begin{array}{l}\text { Tc00.1047053 } \\
509693.190\end{array}$ & $\begin{array}{l}\text { LbrM21_V2.10 } \\
80\end{array}$ & $\begin{array}{l}\text { LinJ21_V3.1 } \\
070\end{array}$ & LmjF21.0880 & $\begin{array}{l}\operatorname{LmxM} 21.088 \\
0\end{array}$ & não tem & não tem & não tem & não tem \\
\hline $\begin{array}{l}\text { Tc00.10470535 } \\
09693.190\end{array}$ & $\mathrm{G}$ & $\begin{array}{l}\text { Tc00.1047053 } \\
506457.149\end{array}$ & $\begin{array}{l}\text { LbrM21_V2.10 } \\
80\end{array}$ & $\begin{array}{l}\text { LinJ21_V3.1 } \\
070\end{array}$ & LmjF21.0880 & $\begin{array}{l}\text { LmxM21.088 } \\
0\end{array}$ & não tem & não tem & não tem & não tem \\
\hline $\begin{array}{l}\text { Tc00.10470535 } \\
07951.280\end{array}$ & G & não tem & $\begin{array}{l}\text { LbrM29_V2.10 } \\
00\end{array}$ & $\begin{array}{l}\text { LinJ29_V3.1 } \\
010\end{array}$ & LmjF29.0930 & $\begin{array}{l}\text { LmxM08_29. } \\
0930\end{array}$ & não tem & não & não & não tem \\
\hline $\begin{array}{l}\text { Tc00.10470535 } \\
07681.100\end{array}$ & $\mathrm{G}$ & não tem & $\begin{array}{l}\text { LbrM35_V2.31 } \\
10\end{array}$ & $\begin{array}{l}\text { LinJ36_V3.3 } \\
040\end{array}$ & LmjF36.2890 & $\begin{array}{l}\text { LmxM36.289 } \\
0\end{array}$ & $\begin{array}{l}\text { Tb927.10.7 } \\
360\end{array}$ & $\begin{array}{l}\text { Tbg972.10.903 } \\
0\end{array}$ & $\begin{array}{l}\text { TcIL3000.10.6 } \\
340\end{array}$ & não tem \\
\hline
\end{tabular}


Tabela A.1 - Genes de transportadores ABC de T. cruzi alelos e ortólogos a espécies de Leishmania e tripanossomas africanos.

(conclusão)

\begin{tabular}{|c|c|c|c|c|c|c|c|c|c|c|}
\hline $\begin{array}{l}\text { Código do } \\
\text { gene }\end{array}$ & $\begin{array}{l}\text { Subfam } \\
\text { ília }\end{array}$ & Alelo $T$. cruzi & $\begin{array}{l}\text { Ortólogo } L . \\
\text { braziliense }\end{array}$ & $\begin{array}{l}\text { Ortólogo } L . \\
\text { infantum }\end{array}$ & $\begin{array}{l}\text { Ortólogo L. } \\
\text { major }\end{array}$ & $\begin{array}{l}\text { Ortólogo } L . \\
\text { mexicana }\end{array}$ & $\begin{array}{l}\text { Ortólogo } T . \\
\text { brucei }\end{array}$ & $\begin{array}{l}\text { Ortólogo } T . \\
\text { gambiense }\end{array}$ & $\begin{array}{l}\text { Ortólogo } T . \\
\text { congolense }\end{array}$ & $\begin{array}{l}\text { Ortólogo } \\
T . \text { vivax }\end{array}$ \\
\hline $\begin{array}{l}\text { Tc00.10470535 } \\
03593.60\end{array}$ & $\mathrm{G}$ & $\begin{array}{l}\text { Tc00.1047053 } \\
506127.120\end{array}$ & $\begin{array}{l}\text { LbrM27_V2.18 } \\
40\end{array}$ & $\begin{array}{l}\text { LinJ27_V3.1 } \\
600\end{array}$ & LmjF27.1700 & não tem & não tem & não tem & não tem & não tem \\
\hline $\begin{array}{l}\text { Tc00.10470535 } \\
06127.120\end{array}$ & $\mathrm{G}$ & $\begin{array}{l}\text { Tc00.1047053 } \\
503593.60\end{array}$ & $\begin{array}{l}\text { LbrM27_V2.18 } \\
40\end{array}$ & $\begin{array}{l}\text { LinJ27_V3.1 } \\
600\end{array}$ & LmjF27.1700 & não tem & não tem & não tem & não tem & não tem \\
\hline $\begin{array}{l}\text { Tc00.10470535 } \\
04425.70\end{array}$ & $\mathrm{G}$ & $\begin{array}{l}\text { Tc00.1047053 } \\
509331.200\end{array}$ & $\begin{array}{l}\text { LbrM23_V2.04 } \\
20\end{array}$ & $\begin{array}{l}\text { LinJ23_V3.0 } \\
430\end{array}$ & LmjF23.0380 & $\begin{array}{l}\text { LmxM23.038 } \\
0\end{array}$ & $\begin{array}{l}\text { Tb927.8.23 } \\
80\end{array}$ & Tbg972.8.1830 & não tem & $\begin{array}{l}\text { TvY486_0 } \\
801810\end{array}$ \\
\hline $\begin{array}{l}\text { Tc00.10470535 } \\
09331.200\end{array}$ & $\mathrm{G}$ & $\begin{array}{l}\text { Tc00.1047053 } \\
504425.70\end{array}$ & $\begin{array}{l}\text { LbrM23_V2.04 } \\
20\end{array}$ & $\begin{array}{l}\text { LinJ23_V3.0 } \\
430\end{array}$ & LmjF23.0380 & $\begin{array}{l}\operatorname{LmxM} 23.038 \\
0\end{array}$ & $\begin{array}{l}\text { Tb927.8.23 } \\
80\end{array}$ & Tbg972.8.1830 & não tem & $\begin{array}{l}\text { TvY486_0 } \\
801810\end{array}$ \\
\hline $\begin{array}{l}\text { Tc00.10470535 } \\
09617.80\end{array}$ & $\mathrm{H}$ & $\begin{array}{l}\text { Tc00.1047053 } \\
509669.30\end{array}$ & $\begin{array}{l}\text { LbrM29_V2.17 } \\
50\end{array}$ & $\begin{array}{l}\text { LinJ29_V3.1 } \\
780\end{array}$ & LmjF29.1640 & $\begin{array}{l}\text { LmxM08_29. } \\
1640\end{array}$ & não tem & não tem & não tem & $\begin{array}{l}\text { TvY486_0 } \\
303490\end{array}$ \\
\hline $\begin{array}{l}\text { Tc00.10470535 } \\
09669.30\end{array}$ & $\mathrm{H}$ & $\begin{array}{l}\text { Tc00.1047053 } \\
509617.80\end{array}$ & $\begin{array}{l}\text { LbrM29_V2.17 } \\
50\end{array}$ & $\begin{array}{l}\text { LinJ29_V3.1 } \\
780\end{array}$ & LmjF29.1640 & $\begin{array}{l}\text { LmxM08_29. } \\
1640\end{array}$ & não tem & não tem & não tem & $\begin{array}{l}\text { TvY486_0 } \\
303490\end{array}$ \\
\hline $\begin{array}{l}\text { Tc00.10470535 } \\
10381.20\end{array}$ & $\mathrm{H}$ & $\begin{array}{l}\text { Tc00.1047053 } \\
506905.40\end{array}$ & $\begin{array}{l}\text { LbrM19_V2.02 } \\
80\end{array}$ & $\begin{array}{l}\text { LinJ11_V3.0 } \\
040\end{array}$ & LmjF11.0040 & $\begin{array}{l}\text { LmxM11.004 } \\
0\end{array}$ & não tem & não tem & não tem & $\begin{array}{l}\text { TvY486_1 } \\
107590\end{array}$ \\
\hline $\begin{array}{l}\text { Tc00.10470535 } \\
06905.40\end{array}$ & $\mathrm{H}$ & $\begin{array}{l}\text { Tc00.1047053 } \\
510381.20\end{array}$ & $\begin{array}{l}\text { LbrM19_V2.02 } \\
80\end{array}$ & $\begin{array}{l}\text { LinJ11_V3.0 } \\
040\end{array}$ & LmjF11.0040 & $\begin{array}{l}\text { LmxM11.004 } \\
0\end{array}$ & não tem & não tem & não tem & $\begin{array}{l}\text { TvY486_1 } \\
107590\end{array}$ \\
\hline $\begin{array}{l}\text { Tc00.10470535 } \\
11501.30\end{array}$ & $\mathrm{H}$ & $\begin{array}{l}\text { Tc00.1047053 } \\
511753.100\end{array}$ & $\begin{array}{l}\text { LbrM30_V2.14 } \\
50\end{array}$ & $\begin{array}{l}\text { LinJ30_V3.1 } \\
390\end{array}$ & LmjF30.1330 & $\begin{array}{l}\text { LmxM29.133 } \\
0\end{array}$ & $\begin{array}{l}\text { Tb927.6.28 } \\
10\end{array}$ & Tbg972.6.2580 & $\begin{array}{l}\text { TcIL3000.6.22 } \\
90\end{array}$ & $\begin{array}{l}\text { TvY486_0 } \\
602290\end{array}$ \\
\hline $\begin{array}{l}\text { Tc00.10470535 } \\
11753.100\end{array}$ & $\mathrm{H}$ & $\begin{array}{l}\text { Tc00.1047053 } \\
511501.30\end{array}$ & $\begin{array}{l}\text { LbrM30_V2.14 } \\
50\end{array}$ & $\begin{array}{l}\text { LinJ30_V3.1 } \\
390\end{array}$ & LmjF30.1330 & $\begin{array}{l}\text { LmxM29.133 } \\
0\end{array}$ & $\begin{array}{l}\text { Tb927.6.28 } \\
10\end{array}$ & Tbg972.6.2580 & $\begin{array}{l}\text { TcIL3000.6.22 } \\
90\end{array}$ & $\begin{array}{l}\text { TvY486_0 } \\
602290\end{array}$ \\
\hline
\end{tabular}




\begin{abstract}
A
SCCRAEVNEPVMPSASSLESDDQIAPKQKGNEPQIEDYS I IAPGESIKGSVAQFDAVE QNKSSVSGRF I I PVSWHNLSYSANGTKILCGLTGTALPSRCLAVMGSSGAGKTTFLNAIS DRL TISRTLKLTGKRQLGDLEYKRHYRRMVGFVAQDDI LSPRA PEDSLRFSLRVRRG TS ISETNKFVEE LEELRLVHCRE IVGIPGLVSGLSGGERKR I I GVELICDPKILLLDEP TSGLDSVTSVKIVHLLNNIARTGRTVIYTIHQPTAETLTYFDDLMLLTGGRCAYHGTMAK SVEYFESIGFPCPERY PSDFFMKLLQDPEISKVLVKKWKSYLKHGVR PHT MVELNPN PSESPTAKNIESYLGRFGSTSCIQFQELFRRFSMDLSRNHVY IFSHFIQAAFFAVIVGLI FLNVKDDLAGMQDREGVFFMVTMNRAMGQTF IMVNS FMQDKALYVREQMVGSYSPF IFFL SKTLVEFPMRVFFAFLECCILYWMVGLYRQAGAFFYYFAVIALLTEVASGLGFAIGATFK SLVVASGTAPVI LLPLAMVGGLLANTDRLHPYWYWLEKPS F IRQAY I LLARNEFKHIDH I RCDGRGKPPGFCKDKPQNGEDILRQLGFQQKQYENWVLWLTLALLYIAFRGWAVISLYSA ARTKF
\end{abstract}

\title{
B
}

ISCCRAEVNEPVIPSSASSLESDDQIAPKQKGNEPQIEDYSI IAPGESIKGSVAQFDAVE QNKS SVSGRF I I PVSWHNLSYSANGTKI LCGLTGTALPSRCLAVMGSSGAGKTTFLNAIS DRL SRTLKLTGKRQLGDLEYKRHYRRMVGFVAQDDILSPRA PEDSLRFSLRVRRG TS ISETNKFVEE LEELRLVHCRE IVGIPGLVSGLSGGERKR S IGVELICDPKILLLDEP SGLDSVTSVKIVHLLNNIARTGRTVIYTIHQPTAETLTYFDDLMLLTGGRCAYHGTMAK SVEYFESIGFPCPERY PSDFFMKLLQDPEISKVLVKKWKSYLKHGVR PHT AVELNPN PSESPTAKNI S S LGRFGSTSCIQFQELFRRFSMDLSRNHVY IFSHFIQAAFFAVIVGLI FLNVKDDLAGMODREGVFFMVTMNRAMGQTF IMVNS FMQDKALYVREQMVGSYSPFIFFL SKTLVEFPMRVFFAFLECC ILYWMVGLYRQAGAFFYYFAVIALLTEVASGLGFAIGATFK SLVVASGTAPVI LLPLAMVGGLLANTDRLHPYWYWLEKP SF IRQAY I LLARNEFKHI DH I RCDGRGKPPGFCKDKPQNGEDILRQLGFQQKQYENWVLWLTLALLYIAFRGWAVISLYSA ARTKF

\section{$\mathbf{C}$}

SCCRAEVNEPVIPSSASSLESDDQIASKQKGNEPQIEDYS I IAPGFFIRGSVAQFDAVE QNKS SVSGRF S I PVSWHNLAYSANGTKILCGLTGTALPSRCLAVMGSS GAGKTTFLNAIS DRL STTLKLTGKRQLGDLEYKRHYRRMVGFVAQDDILSPRA PEDSLRFSLRVRRGTS ISETNKFVEE LEELRLVHCRE IVGIPGLVSGLSGGERKR S IGVELICDPKILLLDEP TSGLDSVTSVKIVHLLNNIARTGRTVIYTI HQPTAETLTYFDDLMLLTGGRCAYHGTMAK SVEYFES IGFPCPERY PSDFFMKLLQDPEISKVLVKKWKSYLKHGVR PHT IAVELNPN PSESPTAKNI 1 S LSMF \&S SCIQFQELFRRESIDLSRNHVY IFSHFIQAAFFAVIVGLI FLNVKDDLAGMQDREGVFFMVTMNRAMGQTF IMVNS FMQDKALYVREQMVGSYSPFIFFL SKTLVEFPMRVFFALLECCILYWMVGLYRQAGAFFYYFAVIALLTEVASGLGFAIGATFK SLVVASGTAPVILLPLAMVGGLLANTDRLHPYWYWLEKPSFIRQAY ILLARNEFKHINH I RCDDRGKPPGFCKDKPQNGEDILRQLGFQQKQYESWVLWLTLALLYIAFRGWAVISLYSA ARTKF

Figura A.3 - Sequência proteica completa de TcABCG1 de três grupos de cepas. Painel A: sequência proteica de TcABCG1 do haplótipo Não-Esmeraldo de CL Brener; Painel B: sequência proteica TcABCG1 de VL10 ou do haplótipo Esmeraldo de CL Brener, que são idênticas; Painel C: sequência proteica TcABCG1 de Silvio ou de YuYu, que são idênticas. A posição dos sítios de modificações pós-traducionais são identificados em cores. Sítios de fosforilação em Serina, Treonina e Tirosina em verde, marrom e azul, respectivamente; Sítios de glicolização em amarelo; Sítios de acetilação em cinza; Sítios de metilação em rosa. Os sítios de fosforilação que diferenciam as sequências em relação à cepa referência (haplótipo Não-Esmo de CL Brener) estão destacados em caixa vermelha nos Painéis B e C. 